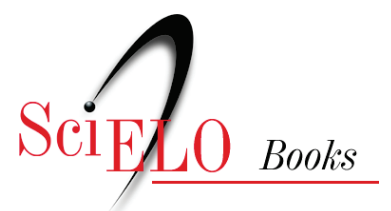

\title{
O sistema de justiça
}

\author{
Maria Tereza Sadek (org.)
}

SADEK, MT, org. O sistema de justiça [online]. Rio de Janeiro: Centro Edelstein de Pesquisas Sociais, 2010. 137 p. ISBN: 978-85-7982-039-7. Available from SciELO Books $<$ http://books.scielo.org $>$.

\section{(1) (1)(2)}

All the contents of this chapter, except where otherwise noted, is licensed under a Creative Commons Attribution-Non Commercial-ShareAlike 3.0 Unported.

Todo o conteúdo deste capítulo, exceto quando houver ressalva, é publicado sob a licença Creative Commons Atribuição Uso Não Comercial - Partilha nos Mesmos Termos 3.0 Não adaptada.

Todo el contenido de este capítulo, excepto donde se indique lo contrario, está bajo licencia de la licencia Creative Commons Reconocimento-NoComercial-CompartirIgual 3.0 Unported. 


\section{Maria Tereza Sadek \\ Organizadora}

\section{O SISTEMA DE JUSTIÇA}

Esta publicação é parte da Biblioteca Virtual de Ciências Humanas do Centro Edelstein de Pesquisas Sociais - www.bvce.org

Copyright (c) 2010 Maria Tereza Sadek, André Luiz Faisting et al.

Copyright (c) 2010 desta edição on-line: Centro Edelstein de Pesquisas Sociais Ano da última edição: 1999

Nenhuma parte desta publicação pode ser reproduzida ou transmitida por qualquer meio de comunicação para uso comercial sem a permissão escrita dos proprietários dos direitos autorais. A publicação ou partes dela podem ser reproduzidas para propósito não comercial na medida em que a origem da publicação, assim como seus autores, seja reconhecida.

ISBN 978-85-7982-039-7

Centro Edelstein de Pesquisas Sociais

www.centroedelstein.org.br

Rua Visconde de Pirajá, 330/1205

Ipanema - Rio de Janeiro - RJ

CEP: 22410-000. Brasil

Contato: bvce@centroedelstein.org.br

Rio de Janeiro

2010 
O sistema de justiça

Maria Tereza Aina Sadek

As interações dos profissionais do direito em uma comarca do Estado de São Paulo

Maria da Gloria Bonelli

O dilema da dupla institucionalização do Poder Judiciário: o caso do Juizado Especial de Pequenas Causas....

André Luiz Faisting

\section{O Ministério Público e a Constituinte de 1987/88}

Fábio Kerche
O principal objetivo deste texto é descrever e analisar o sistema de justiça, tal como ele é vivido pela população e por algum de seus integrantes. Procuraremos analisar o perfil dos principais agentes deste sistema e apontar os caminhos normalmente percorridos pelo cidadão que procura justiça. Para isto recorreremos fundamentalmente a observações qualitativas realizadas em comarcas de diferentes tamanhos e características. Utilizaremos também dados de fontes secundárias, muito embora eles só tenham a função de contextualizar o problema em discussão.

\section{$\mathbf{O}$ acesso à justiça}

Tem se tornado lugar comum na literatura e no noticiário sobre a sociedade brasileira o alto potencial de conflito existente. Cenas de violência têm habitado o cotidiano, ao lado de um sem número de comportamentos vistos como destoantes de uma vida minimamente civilizada. As causas são inúmeras e entre elas, as mais repetidas, tanto nas análises acadêmicas como pelos meios de comunicação, são aquelas provocadas por questões estruturais.

Ainda que não haja evidência empírica que apoie a hipótese segundo a qual a pobreza, a crise econômica, o desemprego estejam diretamente relacionados a taxas de criminalidade ${ }^{1}$, não há como negar que formam um terreno propício à ebulição de conflitos. De fato, a complexidade da sociedade brasileira e, sobretudo, a sua má distribuição da renda, têm sido fatores que estimulam o alto potencial de conflito e a escalada da violência, mesmo que não expliquem nem comportamentos que dificultam o convívio social e menos ainda a descrença nas instituições. O quadro social é dramático, marcado por profundas desigualdades.

* Este artigo reproduz parcialmente relatório de pesquisa financiado pela Fundação Ford.

${ }^{1}$ Cláudio C. Beato E, em "Determinantes da Criminalidade em Minas Gerais", in Revista Brasileira de Ciências Sociais, vol. 13, n. 37, junho de 1998, realizou um excelente estudo sobre relações entre taxa de criminalidade e variáveis estruturais. Embora os dados sejam circunscritos ao estado de Minas Gerais, a análise coloca em xeque interpretações que correlacionam pobreza e criminalidade e mostra a importância da variável espacial. 
Segundo dados oficiais, os pobres chegam à casa dos milhões, representando cerca de $30 \%$ da população. A distância entre ricos e pobres é abismal e tem aumentado nos últimos anos (em 1960, os 10\% mais ricos tinham renda 34 vezes superior à dos mais pobres; em 1990, a diferença mais do que duplicou, passando a ser de 78 vezes; e em 1998, segundo dados do Banco Interamericano de Desenvolvimento, os 10\% mais ricos possuíam quase a metade $-47 \%$ - de toda a renda nacional).

Por outro lado, houve uma significativa mudança no que se refere aos indicadores de urbanização. Enquanto em 1940 a população urbana representava 31\%, em 1970 atingiu a casa dos 68\% e em 1990 passou a $79 \%$. Entre os anos 40 e 80 surgiram no país mais de 400 novas cidades (em 1950 o Brasil contava com 96 cidades com mais de 20 mil habitantes, em 1985 já eram 500). Ou seja, em um intervalo de menos de 30 anos, a população brasileira transformou-se de predominantemente rural em urbana. O ritmo e a forma como este processo se verificou provocou desenraizamento, desagregações de famílias, perda de laços primários e a consequente atomização de indivíduos em cidades grandes, inchadas, desordenadas, com cinturões de miséria e gritantes deficiências na prestação de serviços.

Ao lado desses traços, outras características não estruturais poderiam ser igualmente listadas como responsáveis pela magnitude dos indicadores relativos à criminalidade e a toda sorte de conflitos: a corrupção, a impunidade, os baixos índices de escolaridade, práticas ilegais perpetradas por agentes estatais, a descrença nas instituições e nas leis.

Diante deste quadro, marcado por uma excessiva potencialidade de explosão de conflitos, seria de se supor que a instituição encarregada de resolvê-los ocupasse um lugar central tanto no cotidiano dos cidadãos quanto nas preocupações dos acadêmicos em geral.

No entanto, não é isto o que ocorre. No que diz respeito aos estudos de cientistas sociais ainda é bastante reduzido o número de pesquisas e de textos traduzindo esforços de investigação e análises sobre o Judiciário ou sobre o sistema de justiça como um todo. No que se refere à população, os dados indicam uma forte descrença tanto nas leis quanto nas instituições encarregadas de sua aplicação. Assim, tanto o Judiciário como as demais instituições de justiça - Ministério Público, Polícia, Defensoria Pública - têm recebido avaliações muito negativas.
Por outro lado, as leis não são vistas como universais, como balizadoras de comportamentos, mas, sobretudo, como instrumentos para punir os "fracos" e redimir os poderosos.

A despeito da existência de explicações díspares sobre as causas do conflito, o fato concreto e inquestionável é que são expressivos os números de relatos referentes a comportamentos que colocam em xeque a convivência pacífica. Apesar disso, dados revelam que apenas um percentual reduzido - cerca de $33 \%$ - entre aqueles que se envolveram em conflitos procuram a justiça e reconhecem nesta instituição a chave para a solução de seus problemas. Observemos com mais detalhe estes números:

Segundo pesquisa, realizada pela Fundação Instituto Brasileiro de Geografia e Estatística, IBGE, no período entre outubro de 1983 a setembro de 1988 registrou-se um total de 10.665.046 conflitos. Destes, 9.119.810 ocorreram na área urbana e 1.545.236 na área rural. A distribuição do total de conflitos por sexo indica que os homens estiveram mais envolvidos em conflitos $(60 \%)$ do que as mulheres $(40 \%)$.

O diferencial entre o montante de conflitos nas áreas urbana e rural é, acompanhado por diferentes padrões no tipo preponderante de conflito. Enquanto na área urbana prevaleceu o conflito conjugal (18.9\%), seguido de perto pelo trabalhista (18.3\%) e por crimes $(17.1 \%)$, na área rural o principal tipo de conflito foi com vizinho (17.7\%), em seguida aparece o que envolvia herança (13.7\%), e o trabalhista (12.4\%). Na área rural os conflitos conjugais representaram apenas $1.7 \%$ do total de conflitos e os problemas criminais $1.3 \%$. Trata-se, como estes percentuais indicam, de duas realidades bastante distintas, não apenas pelo número total de conflitos produzido, mas, sobretudo, pelo tipo prevalecente de litígio.

Também no que se relaciona ao gênero, nota-se diferenças no padrão de conflito. Os homens envolveram-se principalmente em questões trabalhistas $(21.5 \%)$, em problemas criminais $(19.5 \%)$, em separações conjugais (13.1\%) e cobranças de dívidas (11.9\%). Já para as mulheres, o tipo mais frequente de conflito foi o de separação conjugal $(26.1 \%)$, seguido, mas com certa distância, de questões criminais (12.5\%), de herança $(12.3 \%)$ e problemas de vizinhança $(12.1 \%)$.

O levantamento feito pelo IBGE preocupou-se também em focalizar com mais detalhes o último conflito em que as pessoas estiveram 
envolvidas. Chegou-se a um total de 8.641 .761 indivíduos, ou seja, um pouco menos de $10 \%$ da população brasileira.

Alguns comentários podem ser feitos em relação a este primeiro conjunto de dados. Dada a reconhecida potencialidade de conflitos da sociedade, de um lado, e abundantes relatos transmitidos pelos meios de comunicação, de outro, os percentuais relativos ao número total de conflitos parecem ser bastante inferiores àqueles que a intuição sugeriria. Não se trata de colocar em questão os números oficiais, mas de chamar a atenção para algumas variáveis que poderiam explicar o aparentemente pequeno número de indivíduos que assumiram ter estado envolvidos em algum tipo de conflito. Para isso podem contribuir desde o superdimensionamento dos conflitos em geral e da violência em particular realizado pela mídia; o esquecimento e a vergonha dos envolvidos; e até o que poderíamos identificar como a banalização do conflito.

De fato, os meios de comunicação têm dado um espaço crescente aos conflitos, sobretudo à violência. Diariamente toda sorte de crimes compõem a pauta tanto de jornais como da mídia eletrônica, chegando a haver, inclusive, programas centrados neste tema, divulgando atos violentos, não poupando o espectador ou o ouvinte das mais cruéis perversidades. Holofotes buscam o crime, onde quer que ele esteja, nem que, para isso, tenham que forjar um bandido. As complexas relações entre o delito e os meios de comunicação, sem dúvida, mereceriam ser exploradas.

Por outra parte, deve-se acentuar também a importância do esquecimento e da vergonha nos depoimentos dos entrevistados. Como se sabe, diante do pesquisador muitos entrevistados vacilam em registrar suas respostas. Culturalmente, o conflito é visto de forma bastante negativa. Assim, não seria surpreendente a deliberada ou inconsciente omissão de envolvimento em situações desta natureza. Some-se a estas ponderações o que poderia ser caracterizado como banalização da violência, isto é, o fato de que cenas de violência passaram a habitar com tanta frequência o cotidiano, que só são registradas quando ultrapassam determinados limites, limites estes cada vez mais amplos.

Saliente-se, ainda, que dados da Pesquisa Nacional por Amostra de Domicílios (PNAD), publicada em 1988, indicam que, do total de pessoas envolvidas em algum tipo de conflito no ano anterior, mais do que a metade não procurou a justiça estatal - apenas $45 \%$ dos entrevistados o fizeram.
Isto é, $55 \%$ dos que sofreram algum tipo de problema sequer chegaram às portas do judiciário. O fato de um grande número de pessoas não procurar a justiça formal deve ser sublinhado, na medida em que indica tanto que muitos problemas não vêm sendo resolvidos pela instituição encarregada de fazê-lo, como que outros canais podem estar ocupando este espaço.

A resolução pacífica de conflitos pode ser atingida por mais de um mecanismo: por técnicas extrajudiciais, organizações da sociedade civil ou por decisão judicial. As técnicas extrajudiciais de solução de controvérsias são: a mediação, a conciliação e a arbitragem $^{2}$. As organizações da sociedade civil resolvem problemas quer através da intervenção direta de suas lideranças quer em assembleias, nas quais se busca o consenso ou o predomínio da vontade da maioria dos associados. Por fim, o último mecanismo - decisão judicial - supõe, antes de mais nada, o império da lei, a crença nas instituições judiciárias e um mínimo de conhecimento a respeito delas, das leis e de sua aplicabilidade. No linguajar comum este conhecimento aparece nas expressões: "eu sei dos meus direitos", "vou procurar os meus direitos", ou "vou até um tribunal". Quando "direitos" não são entendidos como tais, ou quando são vistos como "favores" não constituem pauta para reivindicações. Ou ainda, quando se sabe que, apesar de haver um direito, de nada adianta o recurso aos canais estatais, porque a apelação estará fadada a não provocar efeitos, configura-se uma situação na qual seria pouco "racional" o apelo aos órgãos do sistema de justiça.

Desta forma, deve-se indagar por que grande parte da população não procura um árbitro, pago pelo poder público, para dirimir conflitos. Ou ainda, como e quais são os mecanismos alternativos que vêm sendo utilizados.

Estas questões são fundamentais, já que da resposta obtida podem-se configurar duas situações polares: uma caracterizada pelo apelo à lei do "mais forte", dada a descrença e/ou inoperância das instituições estatais que deveriam distribuir justiça e, no outro extremo, a presença de organizações públicas, não estatais, com legitimidade para dirimir conflitos de forma

${ }^{2}$ Tanto na mediação como na conciliação, surgida uma divergência, as partes podem indicar uma terceira pessoa, o mediador ou conciliador, que as auxiliará a encontrar o ponto de discórdia, sugerindo soluções, propiciando que as partes, por elas mesmas, ponham fim à controvérsia. $\mathrm{Na}$ arbitragem, as partes escolhem um ou mais de um árbitro - pessoa(s) independente(s) e imparcial(is) - que, após avaliar as alegações das partes e as provas apresentadas, decidirá a questão de acordo com seu julgamento, externado no laudo arbitrai. 
pacífica, indicadoras de uma sociedade civil bastante organizada. No primeiro caso têm-se os linchamentos, os massacres, os extermínios, as matanças, a justiça feita com as próprias mãos e um vasto número de mecanismos que operam à margem e contra a lei; no outro, há entidades públicas, mas não estatais, que operam resolvendo disputas. Os exemplos mais típicos, nesta última situação, são aqueles nos quais igrejas, clubes, sociedades de amigos de bairro, enfim, entidades da sociedade civil têm a legitimidade de seus membros para arbitrar conflitos. Em ambas as situações o sistema de justiça estatal não é ativado, mas as consequências para a sociedade, em um ou outro extremo, são muito distintas. Enquanto uma configura a ausência total de civilidade e praticamente traduz a "guerra de todos contra todos" hobbesiana, a outra propicia, tanto padrões de comportamento comunitários, como de guetos, com baixa integração societal.

Caberia discutir em qual destes extremos seria possível enquadrar a sociedade brasileira. Os dados indicam que estamos distantes de uma situação caracterizada pela presença de fortes organizações da sociedade civil, muito embora não se possa negar a existência de tais instituições. Tem sido mais frequente do que normalmente se admite a atuação de lideranças comunitárias, de sociedades de amigos de bairro, de igrejas, de associações voluntárias, na solução de certos conflitos. Neste sentido, é particularmente comum que membros de certas igrejas, em especial as evangélicas, busquem a resolução de seus problemas junto às suas respectivas lideranças. Este canal faz com que os conflitos vivenciados por membros destas comunidades não ultrapassem as suas fronteiras. Por outro lado, a incapacidade do sistema estatal de impor-se e de dar respostas rápidas e eficientes aos inúmeros conflitos tem estimulado a proliferação de organizações para- estatais, que têm imposto sua própria "lei", tornando a vida, em certos centros urbanos, muito próxima da suposição descrita por Hobbes, da situação em que se encontrariam os homens antes da presença do Estado, de um quadro de barbárie e de guerra selvagem.

Esses dois extremos descrevem situações polares, "típico-ideais" na terminologia weberiana, nas quais as pessoas preferem ou são levadas a buscar a resolução de suas controvérsias totalmente fora do sistema de justiça estatal. Há, contudo, uma parte considerável da população que recorre ao sistema estatal, sem, contudo percorrer todos os passos que compõem um processo judicial. Nesta alternativa, têm se destacado as figuras do delegado de polícia e do promotor público, que acabam exercendo também as funções de conselheiro e árbitro, solucionando muitos dos problemas que chegam até eles. De fato, uma pesquisa feita em Recife, relatada por Joaquim Falcão, conclui que uma vara de justiça penal resolve apenas $13 \%$ do número de casos penais que um comissário resolve. Da mesma forma, pudemos observar em várias das comarcas visitadas que muitas desavenças são resolvidas "extrajudicialmente", quer por delegados, quer por promotores, ou mesmo por funcionários qualificados de fóruns como, por exemplo, assistentes sociais. Ou seja, muito embora alguns milhares de problemas não cheguem até a justiça formal, entendendo por isto todo o percurso que termina com a sentença final proferida por um integrante do poder judiciário, isto não significa que sejam inteiramente "expulsos" do sistema. Pode significar que muitos conflitos encontraram solução através da intervenção de agentes do sistema, sem, no entanto, sujeitaram-se a todas as formalidades que caracterizam um processo judicial. Assim, o fato de um problema não chegar até o juiz não quer dizer, necessariamente, que não foi de alguma forma processado pelo sistema de justiça.

Enfocando-se exclusivamente o total de pessoas que entraram com ação judicial, "verifica-se que a utilização da justiça preponderou nos conflitos por pensão alimentícia (73.4\%), nas questões trabalhistas (66.6\%), nas separações conjugais (53.7\%) e nos conflitos pela posse da terra (51.3\%). Entretanto, em relação aos conflitos de vizinhança (85.1\%), aos problemas criminais $(72 \%)$ e às cobranças de dívida $(71.5 \%)$ foi alta a proporção de pessoas que não se utilizou da justiça para a solução de seus problemas" (FIBGE, Participação Político-Social 1988, volume 1, Justiça e Vitimização, pag. XXXI).

Como se depreende desses percentuais, a busca por uma solução judicial deu-se em maior proporção exatamente nos tipos de problemas em que são mais concretas, mais rápidas e efetivas as consequências da sentença judicial. Assim, o estabelecimento de uma pensão alimentícia redunda compulsoriamente em um montante a ser pago a uma das partes, daí a necessidade imperiosa de uma decisão judicial. Por outro lado, em relação aos problemas criminais, por exemplo, grande parte das vítimas sequer recorre à justiça porque sabe das dificuldades em se encontrar o criminoso e que, na eventualidade dele vir a ser encontrado, são amplas as possibilidades de que não venha a ser punido, especialmente se possuir 
recursos financeiros. Estas dificuldades são sintetizadas nas expressões: "É mais fácil encontrar um ladrão de galinha na prisão do que alguém que provocou danos maiores"; "a polícia prende e a justiça solta"; "a polícia quando quer, acha o criminoso, o problema é querer". Em outras palavras e resumindo: os dados oficiais revelam que o Judiciário é mais procurado exatamente para arbitrar aquelas questões em que sabidamente sua resposta é mais eficiente e mesmo imprescindível; e é menos procurado precisamente quando se trata de solucionar problemas para os quais sua eficiência tem sido muito baixa.

Esta hipótese é confirmada quando se examina a distribuição das pessoas que moveram ação judicial, por ano de estudo. Nas questões em que as respostas da justiça têm sido mais eficientes, não apenas há um maior número de ações como a distribuição por escolaridade dos que entraram na justiça praticamente reproduz a da população como um todo. Ou seja, o ideal de uma justiça eficiente e igual para todos está menos distante da realidade quando se trata de questões para as quais o judiciário está mais equipado e vem demonstrando maior eficiência. Explicando: pode-se sustentar que a distribuição da população por escolaridade desenha uma curva semelhante à da distribuição por renda. Quando a procura por justiça se dá em torno de médias que reproduzem a da população significa que a sua credibilidade é mais alta e perpassa de forma semelhante todos os estratos sociais. Supondo-se que um determinado problema não é exclusivo de nenhum segmento social e que o acesso à justiça é igual para todos, todos deveriam procurá-la em igual proporção. É exatamente isto o que acontece no que se refere à pensão alimentícia. Observa-se, em relação a este problema, que há, de fato, uma maior proporção de pessoas com os níveis mais baixos de escolaridade. Esta distribuição reproduz a da população. A única exceção diz respeito àqueles que não têm instrução e que são exatamente os que não teriam o que reclamar na justiça, por ausência de renda. Nas questões em que o Judiciário é mais deficiente, ocorre o inverso: é menor o percentual de pessoas que o procuram e, quando o fazem, as causas encaminhadas concentram-se em parcelas especificas da população. Por fim, não se pode descartar a hipótese segundo a qual para alguns setores da população é exatamente a falta de eficiência da justiça que estimula a sua procura. Isto é, como se sabe que a justiça é lenta, muitos preferem transferir para o judiciário a solução de suas disputas, uma vez que, desta forma, ganham tempo. Questões que envolvem dívidas e trabalhistas representam os melhores exemplos para o exame desta hipótese.

A variável renda coloca outro problema igualmente importante quando se examina a procura por justiça. $\mathrm{O}$ acesso à justiça é, teoricamente, igual para todos. Entretanto, diferenciais de recursos econômicos podem explicar distintas motivações para ingressar na justiça. Parece ser exatamente isto o que vem ocorrendo. Segundo dados do FIBGE, do total de pessoas que se envolveram em ações judiciais $62 \%$ pagaram pelo serviço de justiça enquanto $38 \%$ o utilizaram gratuitamente. Os conflitos de vizinhança e as ações por pensão alimentícia foram as questões em que mais se recorreu ao serviço gratuito de justiça. Em todos os outros tipos de conflito preponderaram os serviços pagos, especialmente aqueles que envolveram a posse de bens, como cobrança de dívida, herança, desocupação de imóvel e posse da terra.

$O$ reduzido percentual daqueles que se utilizaram gratuitamente da prestação jurisdicional contribui para propagar a imagem popular que se tem da justiça - uma justiça cara, elitista, feita para os ricos, para os que têm posse. Esta representação de uma justiça desigual é ainda agravada pelo fato inquestionável de que é muito diferente o empenho dos advogados contratados daquele dos advogados dativos (nomeados pelo Estado) ou da defensoria pública na defesa dos interesses de seus representados. Dai a crença de que rico não fica na cadeia, que presídios foram construídos para os pobres, para aqueles que não têm condições de pagar seus próprios advogados.

Ora, um dos supostos do Estado democrático é a igualdade de direitos. As desigualdades no acesso e na utilização da justiça acentuam as desigualdades econômicas e sociais. A democratização no acesso à justiça constitui-se em pauta fundamental para a efetivação dos direitos que formam a cidadania. Desta forma, o sistema de justiça opera não apenas como garantidor de direitos, mas também como um espaço no qual há a possibilidade de redução das iniquidades decorrentes das desigualdades de renda e prestígio.

\section{O sistema de justiça}

Como afirmamos, o sistema de justiça é mais amplo do que o poder judiciário. A rigor, o juiz é apenas uma peça de um todo maior. O sistema de justiça envolve diferentes agentes: o advogado, pago ou dativo; o delegado de polícia; funcionários de cartório; o promotor público e, por fim, 
o juiz. Uma controvérsia para transformar-se em uma ação judicial percorre um caminho que tem inicio ou na delegacia de polícia, ou na promotoria, ou por meio de um advogado. Cabe ao juiz examinar esta questão quando ela deixou de ser uma disputa entre particulares, ou entre particulares e órgãos públicos, ou entre diferentes órgãos públicos e transformou-se em uma ação. Daí a expressão: o juiz pronuncia-se sobre os autos e não sobre o que está fora deles.

Este sistema possui uma organização espacial. O critério territorial define as comarcas, que são a menor unidade judicial. As comarcas, por sua vez, classificam-se pelo volume de feitos que abrigam, variando da menor para a maior. Este critério determinará se se trata de uma comarca de primeira entrância ou inicial, de segunda ou intermediária, de terceira ou final, e ainda especial. Esta designação varia de estado para estado, mas todas as unidades da federação distinguem as entrâncias menores das maiores.

Há ainda um critério processual, que definirá o tipo de vara. Caso as questões sejam criminais - vara criminal, caso cíveis - vara cível.

Teoricamente, uma comarca do interior, de primeira entrância (ou entrância inicial, como é designada em alguns estados da federação), abrigando uma ou mais cidades de pequeno porte, possui uma demanda judicial relativamente menor. Esta comarca tem apenas um juiz que deve julgar todos os tipos de processo - civil ou criminal.

As comarcas maiores, ou seja, aquelas que possuem um maior número de feitos são divididas em pelo menos duas varas: uma cível e outra criminal, a cada uma correspondendo um juiz. Nas comarcas de terceira entrância e nas especiais estas varas desdobram-se em outras, formando a $1^{\mathrm{a}}$, a $2^{\mathrm{a}}$, a $3^{\mathrm{a}}$ vara cível; e o mesmo podendo ocorrer no que se refere às questões criminais. Além dessa multiplicação de varas cíveis e criminais, nas entrâncias finais têm-se varas especializadas, como a da família, da infância etc.

A organização do judiciário prevê ainda uma instância de recurso, designada segunda instância, ou os Tribunais estaduais.

Esta organização judicial é acompanhada pelas organizações do Ministério Público e parcialmente pelas Delegacias de Polícia.
Esse complexo sistema judicial é bastante desconhecido da população. O público, em geral, desconhece não apenas o seu funcionamento como também é incapaz de distinguir os papéis e as funções de cada um de seus agentes. Pode-se afirmar que o grau de desconhecimento é universal, não havendo correlação positiva entre escolaridade e conhecimento. Ou seja, mesmo pessoas com grau universitário não possuem conhecimentos mínimos sobre o sistema de justiça e seus diferentes operadores. Não é raro que ignorem a existência de dois agentes inteiramente distintos como o são o juiz e o promotor. O delegado de polícia sequer é visto como pertencente ao sistema de justiça.

Tal desconhecimento por parte da população é reconhecido, com certo desconforto, por juízes, promotores e delegados. Assim, inúmeras vezes, durante a pesquisa, ouvimos promotores queixarem-se de que eram constantemente indagados sobre quando seriam promovidos, tornando-se um juiz. Ou, mesmo um juiz, entre indignado e surpreso, relatando que era cobrado por não ter saído de seu gabinete e prendido um criminoso. E, ainda, um delegado referindo-se à expectativa de que proferisse uma sentença, determinando a pena de um suposto culpado.

Em contraste com a ausência de correlação entre grau de escolaridade e conhecimento sobre o sistema de justiça, verificou-se, durante a pesquisa, que quanto menor o município maior a probabilidade de que seus habitantes conhecessem minimamente as diferenças entre os vários integrantes do sistema de justiça. Efetivamente, nas cidades pequenas, além de ser comum a distinção entre as figuras do juiz, do promotor e do delegado, há noções razoavelmente claras sobre as funções de cada um. Nas comarcas maiores, ao contrário, o mundo da justiça tende a se distanciar de tal forma do cotidiano do cidadão, que dificilmente escapa de apreciações negativas, nas quais todos os seus agentes e atribuições encontram-se misturados.

Para a maior parte da população a figura do juiz resume todo o sistema de justiça. O judiciário é percebido não apenas como o poder que profere sentenças, julgando, mas, também, como uma instituição responsável por fornecer respostas às mais variadas demandas por justiça. Atribui-se ao juiz amplas funções: iniciar uma questão, identificar o culpado, prendê-lo, puni-lo e reparar o mal. E, mais ainda, sua sentença deveria obedecer aos cânones de uma justiça rápida, independente das provas, sensível à opinião pública. Enfim, espera-se do judiciário, justiça no 
sentido mais amplo do termo, como se coubesse ao juiz pronunciar-se tanto sobre questões que constam dos autos como sobre toda e qualquer iniquidade social. Ignora-se, quase inteiramente, que o juiz é um agente passivo, que só opera quando provocado (quer pela promotoria, quer por advogados), baseia-se em provas que constem do processo, e que só pode agir segundo os ditames da lei. Em questões criminais, o judiciário, além de ser ativado, depende de investigações que têm origem em uma delegacia de polícia e de informações colhidas por um cartório. Estes constrangimentos, contudo, são normalmente desconsiderados.

Entre os agentes do sistema de justiça, o mais conhecido da população é o delegado de polícia, menos por suas competências formais e mais por encontrar-se mais próximo do cotidiano do homem comum. Um respeito recheado de medo confere-lhe autoridade. Delegados, com frequência, sobretudo em cidades pequenas, extrapolam suas atribuições: agem arbitrando conflitos, sendo procurados até mesmo para dissuadir a continuidade de disputas. Dizia um delegado em entrevista:

A função social da polícia é muito grande. Nós somos os únicos representantes do poder público que ficamos 24 horas ao dispor do povo. Funcionamos como uma espécie de anteparo: todo problema social cai no delegado. Um juiz ou um promotor não ficam à disposição como nós ficamos; eles são muito mais inacessíveis.

O promotor, em contraste com as figuras do delegado e do juiz, é do ponto de vista de suas atribuições, o mais desconhecido, principalmente nas cidades de porte médio e grande. Sabe-se apenas que se trata de uma autoridade, mas seu perfil é uma incógnita. Deste ponto de vista, está em uma posição ainda mais difícil do que a do juiz. Pois é como se não existisse, como se representasse uma personagem que recebe um titulo que poucos sabem dizer para que serve. É bem verdade que nas cidades menores há uma inversão: o promotor é bastante conhecido, recebendo as mais diversas demandas, participando ativamente do cotidiano da população.

Estas observações têm validade para o país como um todo, independentemente de suas variações regionais. Contudo, como afirmamos, a realidade observada em comarcas menores tende a diferir substancialmente daquela que pode ser apreciada nas maiores. O maior grau de conhecimento sobre o sistema de justiça ou ao menos sobre seus agentes nas comarcas de primeira e segunda entrância tem, provavelmente, a ver com o fato de que nas circunscrições menores as relações pessoais preponderam sobre as impessoais.

Para começar, nas comarcas menores o fórum sempre ocupa um lugar de destaque na organização física da cidade. Ao lado da sede do poder executivo, da câmara dos vereadores, da delegacia de polícia e da igreja é uma referência geográfica obrigatória. Isto, quando não é o caso do fórum coabitar o mesmo espaço físico da prefeitura, como acontece em muitas das pequenas cidades do interior. De toda forma, em ambas as situações, o juiz é conhecido, é identificável e sabe-se até mesmo o seu nome. É uma autoridade reconhecida, e que certamente faz parte da elite local. O mesmo pode ser dito no que se refere ao promotor. Com frequência, o promotor é ainda mais conhecido do que o juiz, já que, por dever de oficio, habitualmente reserva pelo menos dois dias da semana para um contato mais direto com o público. Da mesma forma, a delegacia de polícia é facilmente localizável e costuma ser um local para o qual as pessoas se dirigem em busca de soluções para os mais variados problemas, inclusive para aqueles que pouco têm a ver com uma delegacia de polícia, como por exemplo, internamento hospitalar, abrigo, queixas contra certos serviços públicos, pedido de alimentação.

Nestas comarcas de menor tamanho, o fórum, como dissemos, distingue-se por ser um dos prédios públicos de melhor qualidade. Este traço, se por um lado contribui para montar a imagem da justiça como algo importante, por outro, pode funcionar como um fator de inibição. As pessoas não entram neste espaço público sem demonstrar recato e, mesmo, constrangimento. Estrategicamente, as salas reservadas ao juiz não são de fácil acesso. Normalmente, localizam-se no segundo andar, situação espacial que estimula a imagem do juiz como de alguém distante, fechado em seu gabinete, uma autoridade com a qual não se mantém contato, insensível a pressões. O juiz não recebe o público, só entra em relação direta com a população quando a pessoa passou para uma das seguintes categorias: vítima, acusado ou testemunha. E mesmo nestes casos, as pessoas não falam o que desejam, mas respondem às questões por ele formuladas e sempre em um tom bastante formal. A reverência devida ao juiz é estimulada pelos funcionários que dividem com o juiz o espaço do 
fórum. Estes tratam o juiz com deferência, cerimônia e respeito e, em geral, dificultam o acesso do público às salas ocupadas pela magistratura. É de fácil constatação que todo o cenário montado, mais a forma de se vestir e de falar do juiz, sobretudo nestas comarcas de primeira entrância, contribuem para que os juízes sejam vistos pela população como uma personalidade de máxima importância, em tudo distinto do cidadão comum.

Foi também possível verificar durante o trabalho de campo que os juízes estimulam esta reverência que lhes é conferida. Em primeiro lugar, porque os juízes trabalhando nas comarcas de primeira entrância são, em geral, magistrados recém-ingressos no judiciário. Vindos de fora, são uma incógnita para a população. Nada se sabe sobre sua infância, seus hábitos, sua família. Esta situação, ao mesmo tempo em que marca o início de carreira, é mais sujeita ao controle dos órgãos de cúpula do poder judiciário. Por outro lado, a própria insegurança característica das fases iniciais de carreira estimula um comportamento de maior fechamento à vida social e até de autoritarismo. Além disso, por paradoxal que pareça, assim que um juiz inicia a sua carreira é designado para uma comarca menor, na qual é obrigado a acumular todos os tipos de julgamento, tanto cíveis como penais. Situação que o obriga a ser um "generalista", como classificaram vários dos juízes entrevistados.

Vários depoimentos de juízes, colhidos durante as visitas às comarcas, salientavam como era vivida esta situação de início de carreira:

O juiz para ser respeitado não pode frequentar bares e outros lugares públicos.

A vida de juiz é muito difícil. Tem-se que trabalhar de manhã até a noite. Nós não temos tempo para o lazer, nem para ter contato com os outros.

O juiz é sempre foco de atenção. Aqui, todos sabem a que horas chego para trabalhar, sou controlado o tempo todo.

Não é fácil a vida de um juiz. Vim para cá, sem família, moro na casa do judiciário.

Não tenho luxo. Só trabalho o tempo todo. São muitos os processos.

O juiz, principalmente quando começa, mais do que cursos de especialização, precisaria de uma ajuda psicológica. Ele tem que parecer ser perfeito, mas não tem nenhum tempo para ele mesmo. Não entendo como falam tanto que juiz tem mordomia. Veja, aqui não tem luxo. Ao contrário, divido uma casa com o promotor. Além disso, todo final de semana corro risco de vida, já que vou de carro para a capital, nesta rodovia que é um perigo. Aqui, não faço nada, só trabalho. Trabalho o tempo todo. Não tenho hora nem para comer, ou para dormir.

Fiz concurso e entrei para a magistratura. Fui designado para ser juiz nesta comarca. Quero ser respeitado e cumprir com o meu dever para ser promovido.

É bom não conhecer ninguém nesta comarca. Aliás, procuro manter certa distância. Não tenho amigos e não quero tê-los. Assim é mais fácil manter a imagem de imparcialidade.

Você já imaginou o que aconteceria se eu passasse a frequentar bares? Deixaria os outros pouco à vontade, tentariam me envolver em assuntos da cidade, ficariam vendo quanto eu bebo, o que eu falo.

Sempre alguém iria dizer alguma coisa.

Uma das características da carreira da magistratura (assim como dos integrantes do Ministério Público) é que a ascensão é feita das entrâncias menores para as maiores. Isto pode significar, e com frequência significa que um juiz permanece um espaço de tempo muito curto nas comarcas iniciais ou de primeira entrância. Nestas comarcas são, em geral, muito baixos os estímulos para a sua permanência. São, na maior parte das vezes, cidades pobres, com poucos atrativos culturais e sociais, além de forçarem o juiz a um maior isolamento. Desta forma, assim que pode, o juiz solicita sua transferência para uma comarca maior e mais próxima de sua cidade de origem. Este fato contribui tanto para que o juiz não construa vínculos nas comarcas menores, como para que veja esta situação como uma etapa transitória, de passagem. Isto provoca consequências: as mais visíveis, entre elas, são a falta de conhecimento sobre a realidade em que o juiz atua e a tendência de transformar o ofício de julgar em uma questão excessivamente burocrática e técnica. Para a população, por seu lado, esta grande rotatividade favorece a construção da imagem do juiz como a de alguém distante, hierarquicamente superior, que tem o poder de julgar, sem compromisso com a cidade. 
Neste sentido, o perfil do juiz distingue-se radicalmente daquele do político. Este busca a proximidade, o contato, empenha-se para mostrar-se igual e está sempre disponível para receber seus eleitores e para fazer favores. Toda a performance do juiz, ao contrário, acaba por colocá-lo, aos olhos da população, em uma posição de superioridade, inalcançável até mesmo pelas autoridades eleitas da localidade.

A curta permanência dos juízes nas comarcas deve-se, em grande parte, ao fato de que, especialmente nos últimos anos, a ascensão na estrutura do Judiciário vem sendo feita de forma muito rápida. Um juiz pode ficar menos de seis meses em uma comarca antes de ser promovido. A abertura de novos postos e a carência no número de magistrados fazem com que esta mobilidade seja intensa. A alta rotatividade, que vem marcando a fase inicial da carreira, e a atitude dos juízes face a ela, permitiu-nos distinguir duas estratégias diferentes entre os membros da magistratura.

Há aqueles que, de fato, estão apenas de passagem e que ambicionam chegar o mais rapidamente possível em uma comarca de terceira entrância e, por outro lado, aqueles que têm por objetivo ser sempre o que designam um "juiz de interior". Estes últimos, em geral, são mais sensíveis aos problemas sociais da localidade e enxergam a magistratura como uma vocação. Constroem a imagem de si mesmos e da profissão como de sacrifício, de sacerdócio, de alguém que foi alçado à posição de árbitro, que cultiva a imparcialidade e que deve viver no isolamento. $O$ fato da profissão dar-lhes o privilégio de julgar seus semelhantes, decidindo sobre suas vidas, compõe o núcleo central do argumento. No primeiro caso, diferentemente, salientam-se as más condições de trabalho, suas próprias qualidades intelectuais e a intenção de ascender aos mais altos postos da magistratura. Neste modelo, mais do que a posição de árbitro, chama-se atenção para a importância da instituição judiciária, vista como uma instituição que deveria desfrutar de mais prestígio e poder - traços nunca suficientemente reconhecidos pelos que são externos a ela.

Mas, tanto no que se refere a um tipo como ao outro - o "juiz sacerdote" e o "juiz de carreira" -, é sempre possível encontrar um forte denominador comum, demonstrando como tem sido exitosa a socialização feita pela instituição na construção do modelo de profissional desejado. Assim, apesar destas distinções, o grau de semelhança no discurso dos juízes é apreciável. As diferenças são tênues e sempre aparecem naquilo que os próprios juízes designam como pormenor e que o pesquisador só é capaz de salientar depois de um convívio mais longo e de entrevistas em profundidade. De fato, pesquisa realizada pelo IDESP junto à magistratura em 1993 demonstra a existência de uma extraordinária homogeneidade entre os integrantes da magistratura, quer quando manifestam sua opinião sobre o judiciário quer sobre sua missão básica, independentemente do tempo na carreira ou da entrância em que estavam servindo no momento das entrevistas.

Apesar desta homogeneidade é possível detectar movimentos que veem questionando o mito tradicional do "bom juiz como um ser distante da realidade", propondo uma maior abertura às transformações sociais e refletindo uma preocupação com um papel mais ativo da magistratura. Não apenas são significativas as atuações de um grupo ligado ao chamado "direito alternativo", ou "juízes para a democracia", como nas próprias escolas oficiais de preparo dos juízes têm sido notáveis essas mudanças.

Neste sentido, vale a pena reproduzir um texto do juiz José Renato Nalini, da Escola Paulista da Magistratura. Em artigo intitulado "O Magistrado e a Comunidade" procura situar os desafios do juiz numa sociedade em transformação, na qual torna-se difícil conciliar sua missão com as vivências típicas do homem moderno. Diz ele:

Na visão tradicional e clássica, o Juiz é aquele ser asséptico e distante dos seus, dotado da terrível missão de julgar os iguais, o que o impede de ser um deles. Para preservar a imparcialidade e a independência, atributos sobre os quais se funda a segurança da Justiça humana, é-lhe vedado conviver em normal relacionamento. É-lhe defeso vincular-se afetivamente. Amizades íntimas ou inimizades capitais estão proscritas. Cidadão acima de qualquer suspeita, deve sobrepairar entre os demais, garantido-se a tranquilidade propiciadora do julgamento isento.

Nada obstante, o Juiz é homem de seu tempo. O exercício de função diferenciada e com previsão constitucional é insuficiente para libertálo das angústias de uma inflação em descontrole, ou para torná-lo imune às modificações dos costumes, da moral e dos valores.

(...)

Os conservadores adotarão a postura inerte, contida nos cânones ortodoxos que inspiram o traçado do perfil ideal do Juiz: o reino do Juiz não é deste mundo. (...) 
É imprescindível o repensar da carreira, em termos de prestação social a que têm direito os mantenedores do equipamento público estruturado, para se chegar à certeza de que a comunidade pede, espera e tem direito a uma atuação mais intensa dos seus Juízes, além da estrita prestação jurisdicional.

Integrante da elite intelectual, remunerado - ainda que, sob certas conjunturas, de forma não totalmente digna - com os maiores vencimentos dentre os assegurados aos titulares dos cargos públicos,

o Juiz não pode se converter em mero burocrata. (Lex Editora, 1994)

O dia a dia de um fórum distingue, separando acentuadamente, o desempenho do juiz e do promotor, apesar de ambos atuarem no mesmo espaço físico. Enquanto o juiz ou está em seu gabinete, fechado, examinando processos ou na sala de audiências em sessão, o promotor, durante a maior parte do tempo, encontra-se em sua sala, tem as portas abertas, recebe a população. Um e outro se orientam por diferentes concepções sobre a imagem ideal de seu respectivo papel profissional: o bom juiz é aquele que não se pronuncia sobre os problemas, não emite opinião; o bom promotor, ao contrário, é aquele que é comprometido com as causas sociais, um defensor do interesse público, está sempre atento às possíveis transgressões à Lei.

Tais imagens produzem consequências na percepção que cada um deles tem sobre o outro. Os mais críticos em cada uma das instituições sublinham as diferenças, de forma a valorizar o seu próprio papel. Assim, o juiz vê o promotor como um agente que retarda a sentença, como alguém que pode dificultar o seu trabalho, já que tem atribuições que interferem no processo e, no limite, como alguém estranho à justiça e sem responsabilidade. Tais críticas tenderam a se acentuar após a Constituição de 1988, que conferiu maiores poderes ao Ministério Público, tornando-o independente tanto do Executivo quanto do Judiciário. O promotor crítico, de seu lado, identifica no juiz um burocrata do julgamento, um agente passivo, ao contrário dele, que tem o poder de iniciar uma ação. Estas imagens sofrem diferenças de um estado para outro. Em São Paulo, por exemplo, são acentuadas as críticas da magistratura ao Ministério Público. As conhecidas ligações do Ministério Público com o Executivo, particularmente durante os governos Quércia e Fleury, contribuíram para estimular uma imagem negativa da instituição, ainda que se reconheça a importância das mudanças legais. As relações com o executivo são vistas de forma crítica pelos juízes, considerando-as um malefício, já que implicam, de acordo com seu julgamento, uma politização da instituição e de seus membros. Esta percepção foi atenuada nos últimos anos, após o início do primeiro governo Covas, quando o Ministério Público passou a exibir uma imagem de maior independência em relação ao executivo.

Formalmente, o promotor é o representante da sociedade, cabendo a ele acusar em nome da justiça pública, promover a ação penal pública, requisitar da polícia o inquérito policial e diligências investigatórias, zelar para que o poder público respeite os direitos assegurados pela Constituição, conduzindo inquéritos civis e propondo ações civis públicas para a defesa dos interesses individuais indisponíveis e dos interesses sociais. Para cumprir seu papel legal, os integrantes do Ministério Público reservam um tempo em sua agenda para um contato direto com a população.

De fato, em todas as cidades de tamanho pequeno e médio que visitamos, pudemos observar o desempenho da promotoria no atendimento ao público. Eram antessalas repletas de populares, filas pelos corredores, pessoas trazendo problemas na esperança de vê-los resolvidos. Este atendimento, na maior parte das vezes, funciona como um filtro para as questões que são passíveis de se transformar em uma ação judicial. Assim, é um casal que deseja se separar e que vai em busca de uma solução, a senhora que reclama do marido alcoólatra, o senhor que quer regularizar a posse de sua terra, a mulher que se julga traída, o homem que deseja rever seus filhos, a senhora que reclama do esgoto a céu aberto em frente de sua casa, a associação de bairro que quer a construção de um ginásio para prática de esportes etc. Há, por parte do promotor, um trabalho de distinguir os casos; de recomendar como e o que deve ser feito para que se chegue a uma solução judicial; indicar o procedimento para a nomeação de um advogado dativo quando a parte ou as partes não possuem recursos para pagar um profissional do direito. Em suma, promotores informam, orientam, dão encaminhamento a demandas, recebem denúncias e reclamações. Este contato direto com o público transforma o promotor, sobretudo nas cidades pequenas, em um agente estatal muito especial: uma autoridade de fácil acesso, com poderes de resolver uma série de questões, "defensor" dos fracos.

As mudanças constitucionais na concepção do Ministério Público, definindo-o não mais como um órgão do executivo, mas como uma função essencial à Justiça, ampliaram sobremaneira suas atribuições. O novo 
estatuto legal do Ministério Público representou, a rigor, um ganho para os setores mais progressistas da instituição. Assim, estes têm procurado dar publicidade às suas novas funções e à importância de seu papel como guardiões de uma ordem democrática e justa. Tais alterações têm reflexos tanto na sua atuação junto à população como em sua relação com os membros da magistratura e da delegacia de polícia.

Em relação à população, verificou-se um acentuado estímulo para o trabalho em causas que envolvem interesses coletivos. Passou a ser comum encontrar promotores atentos a questões que envolvem o meio ambiente, o consumidor, a improbidade administrativa, o patrimônio histórico e cultural, direitos relacionados à educação, à saúde, à habitação. Assim como tornou-se habitual encontrar promotores proferindo palestras em escolas, clubes, câmaras municipais, discorrendo sobre direitos da população e o papel do Ministério Público.

No que se refere aos demais operadores do sistema de justiça, os ganhos institucionais acrescidos da vitória no antigo esforço dos promotores de se equipararem aos juízes, colocou-os em uma posição vista com desconfiança tanto pela magistratura como pelos delegados de polícia. Estes últimos, sobretudo, apontam os promotores como os organizadores do maior lobby durante os trabalhos da Constituinte e não escondem seu receio de que venham a ser subordinados ao Ministério Público. O testemunho de um deles ilustra tal percepção:

O Ministério Público, como fiscal da lei, sempre pôde fiscalizar a polícia. O problema é quando o Ministério Público quer entrar na nossa área interna, direcionando o inquérito policial, invadindo a função policial. O Ministério Público anda querendo investigar. Mas investigação é atividade da polícia. O Ministério Público deveria olhar mais a sua própria instituição, ao invés de ficar querendo só apontar problemas na polícia.

Os promotores, aparentemente, não têm a mesma aversão aos políticos do que aquela que manifestam, quando podem, os juízes. São figuras recorrentes em seu discurso três personalidades distintas: o exdeputado Ibsen Pinheiro, cassado; o ex-governador Fleury e o ex-deputado federal Hélio Bicudo. Os dois primeiros aparecem como o paradigma do mal político e o último como o bom homem público. Estes depoimentos, contudo, têm que ser analisados com cuidado. Pois, em sua atuação diária, além de responderem a muitas demandas que tradicionalmente chegavam até os políticos locais, não escondem inteiramente o preconceito em relação aos políticos, frequentemente responsabilizando-os pelas dificuldades vividas pela população. Além disso, prefeitos, vereadores e deputados têm se constituído em "alvos" privilegiados para suas investigações.

Por fim, restaria falar do advogado, um agente do sistema de justiça, também observado, ainda que apenas parcialmente, durante o trabalho de campo. São maiores as dificuldades em relatar este caso, uma vez que não se trata de uma figura fixa do fórum, mas que está presente nos julgamentos ou solicitando informações.

As insuficiências dos cursos jurídicos produzem consequências em todos os profissionais que atuam no sistema de justiça: magistratura, promotoria, advocacia, delegados de polícia, defensorias, procuradorias oficiais. No que se refere especificamente aos advogados é notável como se encontram exatamente nesta carreira os dois extremos: os melhores preparados e os que apresentam as maiores deficiências na formação.

Existe uma interpretação, bastante difundida e compartilhada no meio dos advogados, segundo a qual os melhores alunos dos cursos de direito optam profissionalmente pelo exercício da advocacia privada. Competem no mercado e o sucesso de suas carreiras depende das causas e dos clientes que representam. Segundo ainda esta análise, em termos de qualidade, após os advogados viriam os juízes - aqueles que, por medo da competição e da insegurança típica do mercado, preferem uma carreira de funcionário público. Esta seria uma escolha menos arriscada, que garante um emprego vitalício, e salários altos (isto especialmente a partir da década de 80). Depois, se colocariam os promotores - menos brilhantes do que os magistrados, uma vez que os concursos de ingresso seriam mais fáceis e as exigências profissionais menores. Julga-se, também, que os membros do Ministério Público não necessitam ter o mesmo preparo e cuidado dos juízes, já que não proferem sentenças, ficando, desta forma, menos vulneráveis a um controle da qualidade de seus atos. Por último, julgam os advogados, estariam os delegados. Normalmente provenientes das escolas de direito de menor prestígio, de extração social mais baixa e de perfil intelectual menos sofisticado. 
Esta interpretação claramente privilegia o lugar do advogado, vendo todos os demais agentes como inferiores. De toda forma, é possível destacar que no mercado, de fato, uma elite de advogados chega a perceber honorários bastante superiores aos dos juízes e promotores, desfrutando de alto prestígio. No entanto, a média destes profissionais não corresponde à imagem propagada pela elite. Ao contrário, é comum encontrar advogados não militantes, exercendo outras atividades e um grande número tanto de advogados assalariados como daqueles que se convencionou chamar de "porta de prisão".

Os advogados são os porta-vozes de todos os que batem às portas do Judiciário. Embora criticados, são insubstituíveis. Atuam como representantes de seus clientes, dominando um saber que os habilita a defender interesses. Formam o maior grupo profissional de nível superior no Brasil. Apenas no Estado de São Paulo somam mais de 150 mil os que possuem registro na $O A B$, estando, portanto habilitados ao exercício da advocacia. Os bacharéis em direito são em número ainda muito maior, estimando-se que ultrapassem um milhão. Número desta magnitude explica a heterogeneidade do grupo e os repetidos esforços da entidade em garantir direitos exclusivos à profissão.

A Ordem dos Advogados do Brasil é a entidade que representa os advogados, possuindo seccionais em todos os estados da federação. Seu poder e influência são reconhecidos e podem ser mensurados pelos privilégios que conquistou ao longo do tempo. De fato, os advogados contam com prerrogativas que nenhuma outra categoria profissional possui. Para começar, a $\mathrm{OAB}$ não está obrigada a prestar contas ao Tribunal de Contas pelas taxas que recolhe de seus associados. Constitucionalmente pode propor ação direta de inconstitucionalidade, prerrogativa compartilhada com o Presidente da República, governadores, representantes do Legislativo, e Procurador-Geral da República. Tem o poder de indicar juízes e ministros dos tribunais, pelo "quinto constitucional".

No cotidiano do fórum, foi possível ver atuar principalmente os advogados dativos, nomeados e pagos pelo Estado. O empenho destes profissionais assemelha-se bastante à imagem difundida sobre o funcionário público. São, em geral, ou recém-formados, em busca de experiência, ou ao contrário, velhos senhores, que claramente não conseguiram brilhar em suas carreiras.

Em comarcas pequenas, quando postos ao lado de juízes e promotores, os advogados dativos demonstram dois tipos distintos de comportamento. De um lado, há aqueles com muito mais experiência do que os membros do
Ministério Público e da Magistratura, e, de outro, os que recém saíram da faculdade e se deixam inteiramente dominar. É muito comum observar nestas comarcas de primeira entrância que o advogado é muito mais velho do que o juiz e do que o promotor e que tem um maior domínio das técnicas do processo e de julgamento. Além disso, por ser habitante da cidade, em geral, conhece tanto a vítima quanto o réu e as testemunhas. Sua familiaridade com a população permite-lhe, muitas vezes, mais do que orientar, determinar o prosseguimento de um interrogatório.

Nos grandes centros a realidade é bastante diferente. Não apenas porque aí encontram-se os juízes e os promotores mais experientes, como o perfil dos advogados dativos acaba por colocá-los em uma posição de franca desvantagem tanto perante os agentes do sistema de justiça como ante os advogados pagos.

Enfim, os advogados representam uma categoria profissional que mereceria um estudo específico, que as observações realizadas em fóruns não permitem deduzir para a categoria como um todo.

Finalizando este relato, apontaríamos que as enormes carências na prestação jurisdicional dificilmente serão resolvidas apenas com alterações na estrutura do sistema de justiça, muito embora estas sejam imprescindíveis para tornar a justiça mais acessível, rápida e eficiente. Victor Nunes Leal chamava a atenção para a importância da vontade política nos operadores do direito. De fato, observamos durante todas as visitas realizadas às comarcas que diferenças no desempenho de juízes, promotores, delegados, advogados provocam apreciáveis diferenças nas avaliações que a população faz sobre a justiça. 


\section{AS INTERAÇÕES DOS PROFISSIONAIS DO DIREITO EM UMA COMARCA DO ESTADO DE SÃO PAULO*}

\section{Maria da Gloria Bonelli}

As relações profissionais no mundo do Direito são analisadas neste trabalho através do estudo qualitativo de uma comarca de médio porte do interior do Estado de São Paulo. A concepção de mundo do Direito é utilizada para identificar as interações e competições profissionais entre juízes, promotores, advogados, delegados de polícia e funcionários de cartório judicial que lidam institucionalmente com a questão da justiça, na região estudada.

Esta abordagem localiza as posições de onde estes profissionais interagem como condicionantes das competições características das profissões superiores, centradas no monopólio do exercício, no controle do credenciamento, na obrigatoriedade do diploma superior e na expertise. As relações entre as profissões engendram um mundo próprio, com uma dinâmica interna que lhe é peculiar, pensada como um universo com autonomia relativa frente a outras esferas, tais como o mercado ou a política ${ }^{1}$.

A dinâmica dessas relações, refletindo os diversos lugares de onde os profissionais estudados interagem no mundo do Direito, é marcada tanto pelas disputas intraprofissionais quanto pelas interprofissionais. A primeira delas se refere à competição entre os pares e está relacionada à própria

\footnotetext{
* Agradeço a colaboração de Marcio Mucedula Aguiar, Silvana Donatoni e Priscila Canova Mota na realização do trabalho de campo. Esta pesquisa contou com recursos financeiros da Fundação Ford, do CNPq e da FAPESP. Uma versão resumida deste artigo foi publicada na revista Tempo Social, 10:1, maio de 1998.

${ }^{1}$ Tanto a teoria dos campos em Bourdieu (1997) quanto o modelo do sistema das profissões de Abbott dão relevância a esta autonomia relativa. Em Abbott (1988), as relações profissionais formam um sistema próprio que engendra suas mudanças endógenas, através das competições intraprofissionais e interprofissionais. O conceito de campo em Bourdieu não foi construído especificamente para o estudo das profissões, mas como um recurso analítico mais genérico, capaz de identificar as relações objetivas em um espaço social, com autonomia relativa.
}

estratificação de cada ocupação. A segunda examina as disputas entre profissões que atuam em áreas de fronteira ${ }^{2}$.

$\mathrm{O}$ estudo das competições profissionais tende a centrar-se nas disputas jurisdicionais no mercado de trabalho como foco privilegiado de análise, reconhecendo nessas relações a construção de uma estrutura, de um sistema, de um campo com autonomia em relação a outras esferas. Esta pesquisa amplia o enfoque das profissões no mercado, para incluir as suas relações com o Estado, já que as atividades desenvolvidas na comarca são mais associadas ao poder público do que às formas delas se protegerem da concorrência no mercado de trabalho.

O objetivo deste artigo é vincular a perspectiva exposta acima com a lógica que movimenta a comarca investigada. Para tanto, analisaremos as relações profissionais, as redes entre esses indivíduos, as suas características morfológicas, como a origem social e as trajetórias de carreiras, além dos diferentes formatos organizacionais de cada profissão e das suas respectivas estruturas internas, procurando demonstrar como o mundo do Direito elaborado teoricamente tem existência real na prática do exercício profissional.

\section{A estrutura do mundo do Direito na comarca Branca}

A comarca pesquisada, que foi chamada de Branca, é composta de dois municípios e dois distritos, com uma população total em torno dos 177.000 habitantes, em 1991. A comarca é a unidade-base do Poder Judiciário, nela atuam o juiz e os funcionários judiciais, que são vinculados a este poder; e o promotor, que pertence ao Ministério Público e não ao Judiciário. Os advogados e os delegados de polícia ligam-se indiretamente à comarca, nas suas respectivas práticas profissionais. Os advogados representam os interesses de seus clientes, e os delegados de polícia são os responsáveis pela formação do inquérito, que vai dar origem ao processo.

A estrutura organizacional do Ministério Público acompanha a do Poder Judiciário, já que as atividades desempenhadas por ambas as instituições caminham conjuntamente, embora sejam bem demarcadas. $\mathrm{O}$

\footnotetext{
${ }^{2}$ Balanços da bibliografia internacional da Sociologia das Profissões que discutem a concepção de Abbott, e conceituam as competições inter e intraprofissionais podem ser encontrados em Freidson (1998) e Rodrigues (1997).
} 
promotor de justiça representa o lado ativo da justiça e o juiz o seu lado passivo. O juiz não dá partida a um processo. Seu poder é de julgar seu mérito, mas não de dar início à movimentação do sistema judiciário. Este papel cabe ao promotor de justiça, que no caso criminal vai se apoiar num inquérito policial feito por um delegado de polícia, e no caso cível apoia-se numa ação iniciada por um advogado ao dar entrada no cartório judicial.

A Comarca Branca possui quatro varas cíveis, duas varas criminais e um juizado de pequenas causas. Como se trata de uma cidade de médio porte, a comarca é de Terceira Entrância.

O Poder Judiciário possui também comarcas de Primeira Entrância, de Segunda Entrância e de Entrância Especial, de acordo com o tamanho da cidade. Às menores cidades (até 30.000 habitantes) correspondem as comarcas de Primeira Entrância. A Entrância Especial é formada pelas comarcas da capital do Estado. Tanto as comarcas de Primeira, as de Segunda e as de Terceira Entrância quanto as de Entrância Especial vinculam-se à Primeira Instância do Poder Judiciário.

A Segunda Instância configura-se como uma possibilidade de recurso na estrutura do Poder Judiciário. Ela se situa na capital e é formada pelo Tribunal de Justiça, onde atuam os desembargadores, pelo Primeiro Tribunal de Alçada Cível, pelo Segundo Tribunal de Alçada Cível e pelo Tribunal de Alçada Criminal, todos os três com atuação dos juízes de Direito. No Ministério Público, os profissionais vinculados ao segundo grau são procuradores de justiça e os de primeiro grau são promotores de justiça.

O ingresso em ambas as carreiras começa pela posição de juiz substituto ou promotor substituto. Esta denominação é originária do fato do recém-concursado ser designado para trabalhar em uma circunscrição judicial (comarcas maiores que englobam administrativamente as menores) que já possui promotores ou juízes vitaliciados. A progressão na carreira para vitaliciado se dá num prazo de dois anos, mas como há falta de profissionais, o substituto acaba sendo promovido para a Primeira Entrância antes de se tornar vitalício. Conforme vão surgindo vagas eles vão galgando novas posições nas comarcas maiores, desde que se inscrevam para tal. Um juiz ou promotor de Terceira Entrância só se candidata à promoção para Entrância Especial se quiser.
Cada uma das varas que compõem a Comarca Branca conta com um juiz e um cartório judicial. São, portanto, seis juízes, sendo quatro cíveis e dois criminais. O Juizado de Pequenas Causas é acumulado pelos juízes da vara cível, sendo que a direção é exercida por um deles de forma fixa e o trabalho decisório sobre os processos é feito num sistema de rodízio, assumindo a cada seis meses um dos juízes dessas varas. No Ministério Público a distribuição dos promotores pelas áreas se inverte. Há seis promotores, sendo dois ligados à esfera cível e quatro à esfera criminal.

Já as delegacias de polícia da região possuem uma outra estrutura que apresenta pontos de conexão com a do Judiciário e do Ministério Público locais. Elas são vinculadas ao Poder Executivo, que é responsável pela atividade policial militar e civil. Os delegados de polícia vinculam-se à Polícia Civil, desempenhando funções de Polícia Judiciária, enquanto a Polícia Militar faz a parte preventiva do policiamento.

A Delegacia Seccional de Branca abrange os cinco distritos policiais do município, as delegacias de polícia de outros seis municípios da região (Verde, Vermelho, Amarelo, Azul, Marrom e Cinza), além do Primeiro Distrito Policial de Verde, da Delegacia de Investigação de Entorpecentes (DISE), da Circunscrição de Trânsito (Ciretran) da região, da Delegacia de Polícia de Defesa da Mulher e da Delegacia de Polícia de Investigações e Infrações Contra o Meio-Ambiente (DIMA), que entrou em funcionamento em setembro de 1994. A Delegacia Seccional de Branca está subordinada à Delegacia Regional de Prata. Esta é uma das dez delegacias regionais existentes no Estado de São Paulo, que aglutinam as delegacias de sua área. As delegacias regionais se reportam ao DERIN - Departamento das Delegacias de Polícia de São Paulo e Interior, cujo responsável é o delegado geral, chefe da Polícia Civil nomeado pelo Secretário de Segurança Pública.

$\mathrm{Na}$ região estudada, a estrutura organizacional da Delegacia Seccional é maior do que a da Comarca de Branca, abrangendo esses seis municípios que estão sob a jurisdição de outras quatro comarcas. Portanto, a população afeta à Delegacia Seccional era de 283.461 habitantes, em 1991. O número de processos que entraram em tramitação nos cartórios judiciais no ano de 1992 foi de 12.125. O número de inquéritos policiais abertos nas delegacias da Seccional de Branca, em 1993, foi de 3.510. A Delegacia Seccional contava com 29 delegados, sendo duas mulheres. 
Além desses personagens atuando no campo da justiça, os advogados e os funcionários do Poder Judiciário completam as posições existentes em Branca $^{3}$; Lá, a OAB registrava cerca de 580 filiados em 1994, e estimava que 150 profissionais exerciam a advocacia em Branca. O total de funcionários dos cartórios judiciais era de 135.

A comarca é estruturalmente organizada em seis varas e cada uma dessas varas possui um cartório. Há dois fóruns, um criminal, com duas varas e um cível, com quatro varas. A posição mais alta da hierarquia profissional local é a do juiz responsável pela vara, que responde aos desembargadores do Tribunal de Justiça, em São Paulo. Dois cargos estão subordinados diretamente ao juiz: o de diretor de cartório e o de oficial de justiça. Este último está funcionalmente atrelado à vara e não ao cartório. Vinculados ao diretor do cartório estão os escreventes-chefes de setor, os escreventes e os auxiliares judiciários.

Há seis categorias de auxiliar judiciário, mas as quatro primeiras se referem aos faxineiros, às encarregadas da copa e da limpeza do prédio. As funções administrativas são afetas ao topo da escala dos auxiliares judiciários, que desempenham atividades como atendimento ao público, arquivo, autuação de processo e encaminhamento de cargas para advogados, promotores, juízes, contadores e escreventes. O escrevente tem como responsabilidade 'tocar o processo', fazer mandato, preparar ofícios. A habilidade na máquina de escrever e o conhecimento do Português são necessários para a função. $\mathrm{O}$ escrevente-chefe distribui as atividades, encarrega-se da parte de provimentos, do que é publicado no Diário Oficial, e da organização das pastas individuais com o histórico dos funcionários. $\mathrm{O}$ diretor do cartório mantém contato com os chefes, estrutura o organograma do cartório, distribui as funções, supervisiona o trabalho e é o responsável pelo elo entre o juiz e o cartório. Junto com o juiz, decide promoções e a alocação de funcionários em cargos de confiança (alguns cargos de chefia e a posição de oficial-maior, que é o substituto do diretor).

\footnotetext{
${ }^{3}$ Alguns desses profissionais exercem atividades docentes nas faculdades de Direito da região. Ministrar aulas costuma ser uma ocupação secundária que a lei permite ser desempenhada pelos juízes e promotores. Outras atividades profissionais são vetadas a essas duas profissões. Há delegados de polícia que prestam serviços de consultoria em segurança. Em geral, os advogados não sofrem restrições legais para o exercício de outras ocupações.
}

O oficial de justiça cumpre mandatos que partem diretamente do juiz. Ele faz a intimação de uma testemunha para comparecer a uma audiência, dá ciência a um réu, a um devedor executado, cumpre ordens de despejo e penhora de bens. É através do oficial de justiça que o Poder Judiciário executa o que foi determinado. Não há cargos hierárquicos nesta posição, como há no cartório. O oficial de justiça só se reporta ao juiz e é a ele subordinado. O ingresso no Poder Judiciário se dá via concurso, tanto para auxiliar judiciário e escrevente quanto para oficial de justiça e magistrado. O mesmo acontece nas posições do Ministério Público e das Delegacias de Polícia. Entre os recém-formados há a imagem de que o concurso para magistrado é o mais difícil, com exigências de conteúdo superiores às do Ministério Público. Os exames para ingresso nessas carreiras reproduzem a hierarquia profissional, na forma como se percebe a valorização social dessas profissões.

A Comarca Branca contava, em 1994, com 8 diretores de serviços, 23 escreventes-chefes e oficiais maiores, 56 escreventes, 14 auxiliares de justiça, além de 2 fiéis e um menor colaborador. O número de oficiais de justiça era de 31 .

Quanto aos advogados que atuam em Branca, mais de $80 \%$ o fazem nas áreas cível e trabalhista. As ações mais frequentes são as de despejo e cobrança ou aquelas vinculadas à família, como separação judicial, divórcio e pensão alimentícia.

A OAB de Branca estima que $30 \%$ de seus filiados sejam do sexo feminino. Esta seccional da $\mathrm{OAB}$ é responsável pela aplicação do exame da Ordem em 7 municípios da região, como também tem a prerrogativa de acompanhar os advogados destes municípios em situações de perda da liberdade.

\section{O perfil social dos profissionais}

O que dá a estes grupos profissionais uma lógica de pertencer ao mesmo universo é que, além do fato de lidarem com a questão da justiça, vivem cotidianamente uma intensa socialização no mundo do Direito, com uma linguagem própria, um jeito de agir e até uma aparência semelhante no vestir, dada predominantemente pelo ambiente do Fórum. Embora este padrão se modifique nas delegacias, ele é um patamar distintivo para o delegado de polícia, em relação às demais posições na hierarquia interna da 
polícia civil. Os delegados usam paletó e gravata e são bacharéis em Direito, como os advogados, os juízes e os promotores, tendo partilhado uma formação universitária em uma área comum, que atribui características altruístas à justiça e valoriza corporativamente os profissionais que lidam com tais questões.

Por outro lado, apesar dos funcionários de cartório não precisarem ter como pré-requisito obrigatório o diploma de Direito, o mais comum é encontrar entre eles pessoas já formadas ou cursando esta faculdade. Esses funcionários judiciais vivem intensamente a socialização no Fórum, local onde trabalham e reproduzem com mais ênfase o padrão acima de conduta e de valores profissionais.

Embora o grau de exposição a esta lógica e a intensidade do processo de socialização possam ser distintos na trajetória de vida dos informantes, cada profissão que atua neste universo apresenta semelhanças internas que permitem enfocá-las enquanto grupos ocupacionais. Observamos inclusive como o processo de recrutamento tende a priorizar a homogeneização de cada um desses grupos. Analisaremos, portanto, as semelhanças e as diferenças tendo como unidade básica de referência as ocupações mencionadas acima.

\section{Os juízes}

Todos os juízes entrevistados são homens brancos. A maioria deles procede dos estratos sociais inferiores, sendo originários de famílias com baixo grau de escolaridade. Dos seis entrevistados, dois eram filhos de trabalhadores rurais, um o pai era continuo no Tribunal de Justiça, um era metalúrgico, outro era contador e apenas um era filho de advogado. A ascensão social é o padrão na carreira de juiz da Comarca Branca, revelando-se ainda mais intensa do que o processo de mobilidade social ascendente detectada no corpo da magistratura brasileira como um todo ${ }^{4}$.

\footnotetext{
${ }^{4}$ Várias pesquisas realizadas recentemente apontam a mudança do perfil do magistrado brasileiro, em função da mobilidade social, do ingresso de jovens e de mulheres. A Comarca Branca, de Terceira Entrância, diferenciava-se destes dados gerais. Não tinha mulheres, a idade média não era jovem e a origem social dos magistrados tinha uma representação ainda maior dos segmentos mais humildes. Ver os surveys sobre a magistratura, coordenados por Sadek (1995), Vianna (1997), Junqueira, Vieira e Fonseca (1997).
}

Os quatro juízes de origem social mais baixa eram filhos de mulheres cuja atividade estava concentrada no lar. Eram donas de casa. Já os dois restantes eram filhos de professoras.

A faculdade de Direito frequentada pela maioria deles é privada. Embora não tenhamos informação para um deles, encontramos um juiz formado no Mackenzie, dois na Unaerp, em Ribeirão Preto e um na Faculdade Municipal de São Bernardo. Apenas um juiz cursou a USP.

Três dos entrevistados ingressaram na Magistratura bem cedo em suas carreiras profissionais (até 25 anos), dois começaram em torno dos 30 anos (29 anos e 33 anos) e apenas um tornou-se magistrado aos 43 anos. A incidência de juízes que tiveram uma longa experiência profissional em cartório é muito elevada na Comarca Branca. Dos seis juízes, quatro passaram toda a sua juventude trabalhando em cartórios judiciais de outras comarcas, onde ingressaram com idades entre 10 e 13 anos. A intensa socialização no ambiente e nos valores do fórum, quando jovem, favorece a procura por este tipo de carreira, e parece auxiliar a aprovação no exame de seleção. Desses quatro, dois exerceram a advocacia por mais de dez anos antes de ingressar na carreira de magistrado, mas acabaram se redirecionando para ela. Dos demais juízes da comarca Branca, um exerceu a advocacia por pouco tempo e o outro foi promotor por dois anos e meio.

No momento da entrevista, em 1994, a distribuição desses magistrados por faixa etária era: um com mais de 50 anos, dois entre 40 e 49 anos e três entre 30 e 39 anos. O interior de São Paulo é a região de origem da maioria desses juízes, embora nenhum seja de Branca. Apenas um veio da capital de São Paulo e um do Rio de Janeiro.

\section{Os promotores}

Todos os seis promotores são homens, e todos se consideram brancos. Dois desses promotores se recusaram a conceder entrevista, o que reduz a amostra a quatro. Mais ainda do que os juízes, todos os promotores entrevistados fizeram mobilidade ascendente, sendo filhos de pessoas de origem social mais baixa. Dois tinham como ocupação paterna atividades do setor rural, um como trabalhador e outro como sitiante. Os pais dos dois restantes trabalharam, um como escriturário e o outro como contínuo. Diferentemente dos juízes, todos os promotores eram procedentes dos segmentos mais baixos da hierarquia social, não encontrando nenhum de 
origem no estrato médio-alto ou acima. A ocupação materna era a de dona de casa.

A faculdade que todos os entrevistados cursaram era particular e localizava-se fora da capital do Estado. Dois frequentaram a Faculdade de Direito de São José do Rio Preto, um cursou a de Osasco e um fez em Pirassununga.

A faixa etária dos promotores entrevistados oscilava entre 32 e 47 anos. Dois estavam na faixa dos 30 e dois na faixa dos 40 anos. Apenas um deles nasceu na capital de São Paulo e um no Nordeste. Os dois restantes nasceram em municípios do interior do Estado.

A experiência profissional anterior ao ingresso no Ministério Público mostra uma aproximação e uma socialização no universo do Direito, da norma, e da ordem, mas não aponta para a experiência de trabalho no Fórum, como o constatado entre os juízes. Assim, um promotor começou a trabalhar aos 16 anos, num escritório de advocacia, e ficou neste emprego até ingressar no MP dez anos depois. Outro frequentou a escola de sargentos, e foi militar até ingressar na carreira de promotor. Um terceiro, embora aprovado também para a Magistratura, optou pelo Ministério Público. Ele havia cursado a faculdade de História, mas a abandonou preferindo estudar Direito, embora o pai preferisse que ele cursasse Agronomia. Uma trajetória semelhante, de ter contato com outro curso superior antes de ingressar em Direito, também foi observada num promotor que fez uma opção mais tardia, pela carreira do MP Antes, cursara Letras e seguira a trajetória de professor. Atuava como diretor de escola ao mesmo tempo em que exercia a advocacia, quando se tornou promotor.

\section{Os delegados de polícia}

Quando iniciamos o trabalho de campo a Delegacia Seccional de Branca contava com 15 delegados, mas ela recebeu um reforço de 14 novos delegados. Deste total de 29, entrevistamos 18, sendo seis recém-ingressos. Essa amostra é composta de 17 homens e uma mulher. Tal como observado entre os promotores, todos também se consideraram brancos.

Há oito delegados na faixa etária dos 25/30 anos, cinco na faixa dos $31 / 40$ anos e cinco com mais de 40 anos, sendo que o mais velho tinha 51 anos. A última faixa só é encontrada entre os profissionais antigos, mas as duas outras são detectadas em ambos os grupos: os que acabaram de ingressar e os que já trabalhavam antes.

A origem social desses delegados também aponta para o processo de mobilidade intergeracional ascendente, mas com um percurso de distâncias sociais menores. Nenhum dos informantes tinha seu pai trabalhando no meio rural. O ponto de partida mais baixo para a ocupação paterna é o trabalho manual urbano com alguma qualificação. Quatro delegados têm sua origem social no estrato médio-inferior, onde a ocupação do pai era a de motorista, marceneiro ou mecânico; sete no estrato médio-médio (comerciante, dono de táxi, sargento); cinco no estrato médio-superior (professor secundário, oficial de cartório, funcionário público com diploma de advogado) e dois no segmento alto (advogado e contador).

O processo de socialização nos valores do mundo da ordem, seja pela lógica do Direito, seja pela da polícia antecede o ingresso na carreira para oito entrevistados. Estes, já no ambiente familiar conviveram com tais perspectivas uma vez que quatro pais exerceram atividades profissionais na Polícia Militar e na Civil e outros quatro obtiveram título de bacharel em Direito. A maioria dos delegados entrevistados acabou intensificando esta socialização prévia com os valores vigentes neste universo, através do ingresso nas delegacias para trabalhar como investigador ou escrivão de polícia (11 deles). Outros quatro tiveram experiências como militar ou como funcionário do Fórum. Apenas cinco afirmaram não ter experiência profissional nesta área, embora um deles fosse filho de policial, tivesse um irmão delegado e uma irmã que foi investigadora de polícia. $\mathrm{O}$ condicionante da socialização anterior atua fortemente nesta carreira, tal como a tendência endogâmica observada no processo de recrutamento e seleção dos magistrados.

A grande maioria das mães (13 delas) dedicaram-se à atividade doméstica, quatro eram professoras e uma foi cozinheira.

As faculdades de Direito cursadas pelos delegados são todas privadas. A Faculdade de Direito de Branca é a de maior incidência na amostra, com cinco delegados tendo concluído seu curso lá. A grande maioria cursou faculdades particulares do interior do estado ou de municípios da Grande São Paulo, excluindo a capital, onde apenas um estudou, se formando no Mackenzie. 
A região de origem dos delegados entrevistados tem predominância do interior de São Paulo, com destaque para aqueles nascidos nos municípios da Seccional de Branca e redondezas. Dos 14 delegados provenientes do interior, oito são desta área. Há três da capital e um da região do $\mathrm{ABC}$.

\section{Os advogados}

Entrevistamos 16 advogados atuantes na comarca de Branca, sendo cinco mulheres. Como os cinco primeiros entrevistados foram sugeridos pela $\mathrm{OAB}$ local, notamos no decorrer das entrevistas que o critério adotado para a escolha desses nomes privilegiava o sucesso na carreira, embora nos tenha sido informado que a seleção indicava representantes de áreas de especialização relevantes. Para contrabalançar esta predominância de carreiras masculinas bem-sucedidas, optamos por realizar outras entrevistas com uma seleção intencional de advogados e advogadas em posições profissionais diferentes deste padrão de desempenho.

Dos 16 advogados entrevistados, cinco estavam na casa dos 30 anos, quatro estavam na faixa dos 40/50 anos, quatro na dos 50/60 anos e outros três com mais de 60 anos. Dois eram filhos de fazendeiros (um deles também era político), um era filho de dentista, um de professor secundário, outros sete de comerciantes, um pai trabalhava com expedição de mercadorias numa indústria, um como cabeleireiro, um era sitiante, um carroceiro e um último era filho de um trabalhador rural. A ocupação materna predominante é a de dona de casa, embora haja uma professora, uma enfermeira, uma lavadeira e uma trabalhadora rural.

A origem social destes informantes não permite estabelecer uma proporcionalidade para o grupo dos advogados desta comarca, já que representa uma parcela muito pequena do contingente de advogados atuantes na região. Em geral, a mobilidade social ascendente é um fator que caracteriza os profissionais do campo do Direito nesta comarca, mas no caso dos advogados, parece que entre eles são mais facilmente detectados aqueles indivíduos de uma procedência social mais favorecida, oriundos dos segmentos superiores da hierarquia social. Se comparados com os juízes e os delegados da comarca de Branca, há mais profissionais advogados que são filhos de membros das elites locais, embora haja migração para a região e haja também ascensão social local via obtenção do diploma de advogado. Como a maioria dos entrevistados neste grupo profissional é proveniente dos segmentos médios ou altos, as possibilidades concretas de realizarem mobilidade ascendente foram menores, já que partiram de um patamar mais elevado. Em geral, os juízes e os promotores de Branca percorreram distâncias sociais maiores, partindo de famílias mais desfavorecidas e alcançando o topo da hierarquia social. Já os delegados de polícia originam-se principalmente de famílias médias.

Para o exercício da advocacia, os laços sociais e as redes locais parecem ser mais relevantes já que é necessário se obter clientela. As atividades profissionais ligadas ao setor público podem dispensar esta característica, já que a renda mensal não provém deste tipo de vínculo. Este fator pode ter alguma relevância na explicação das diferenças nas origens sociais destes grupos profissionais.

Todos os 16 entrevistados são provenientes do interior do estado de São Paulo, sendo oito deles da região de Branca. Também no que se refere à faculdade de Direito que frequentaram, predominam os cursos particulares do interior do estado, com destaque para a faculdade localizada no município de Branca. Um dos informantes estudou na USP, na capital.

A experiência profissional destes informantes deu-se predominantemente no exercício da advocacia, com escritório próprio, embora o padrão do escritório e da atividade liberal seja bastante diferenciada, de acordo com o grau de profissionalização de cada um deles. Assim, entre os que estavam numa situação mais favorável, havia um exjuiz da Comarca Branca, que após a aposentadoria retomara a atividade de escritório e um advogado que era presidente da $\mathrm{OAB}$ local quando concedera a entrevista. As situações profissionais que estavam numa condição oposta podiam ser ilustradas pelo caso de uma mulher que havia se formado há quatro anos, e que além de dar aulas de inglês em um curso, exercia a advocacia em casa e atendia no escritório de uma conhecida alguns clientes do programa oficial da Secretaria da Justiça, em convênio com a $\mathrm{OAB}$ local, para dar assistência advocatícia à população carente.

Outro padrão de difícil profissionalização é o dos homens que concluíram tardiamente o curso de Direito, ingressando na prática profissional depois dos quarenta anos. Quando este procedimento está ligado ao acúmulo de posições no mercado de trabalho, como funcionário público e advogado, a transição entre as duas atividades parece mais tranquila, já que só se completa com a aposentadoria na primeira ocupação. 
Assim, embora a situação do escritório possa ser menos profissional, as consequências para o advogado são menos dramáticas. Quando esta transição é tardia, mas envolve uma redefinição profissional por perda da posição anterior, o tipo de ingresso possível neste mercado de trabalho torna-se tão adverso que parece marcar o desenvolvimento da profissionalização para sempre, estabelecendo limites no tipo de clientela, nas causas obtidas e nos rendimentos auferidos. Esses advogados se tornam inimigos mortais dos Juizados de Pequenas Causas, que atingem diretamente a faixa de clientela potencial para quem eles se voltam.

Embora a profissão de advogado se distribua por uma hierarquia de status profissional, que tem seu polo dominante entre os sócios das grandes firmas de advocacia, em Branca não identificamos nenhum advogado classificado nesta posição. Outra situação que também não localizamos na região é a dos advogados assalariados por empresas. O padrão é o da terceirização destes serviços. A polarização da condição do exercício profissional se dá sob o rótulo da atividade liberal. Todos os entrevistados se definiram como advogados atuando em escritório, mas a estratificação dentro desta denominação era muito grande e gerava, além das disputas comuns por clientes, conflitos mais substantivos motivados pela identificação de uma desigualdade de oportunidades, de favorecimentos, de panelinhas e outras tensões decorrentes das competições provenientes da segmentação profissional.

Embora haja uma barreira dificilmente ultrapassada por aqueles que se profissionalizaram tardiamente, quando a trajetória no campo se inicia mais cedo, as limitações parecem menos segmentadas. Ou seja, é possível alguma ascensão e mudança na situação profissional conforme a carreira do jovem advogado vai se desenvolvendo. Assim, são principalmente os informantes mais jovens, que estão construindo sua profissionalização, que recorrem aos convênios entre a $\mathrm{OAB}$ e a Secretaria de Justiça para obter clientes, adquirir experiência e algum rendimento. Estes convênios garantem os serviços de advogado para as populações carentes e remuneram o profissional com valores muito abaixo dos praticados no mercado privado. Os advogados se inscrevem nestes convênios e recebem clientes por rodízio, seguindo a ordem da lista de adesão. Esta prática pode ser abandonada depois que a carreira do advogado se consolida um pouco mais.
O tamanho do escritório, a quantidade de advogados atuando, o perfil da clientela, o tipo de causa e a área de especialização dão a dimensão da estratificação dentro da carreira. O exercício liberal esconde discrepâncias muito grandes nas condições concretas de trabalho, mas, apesar de os jovens estarem em uma situação bem mais difícil do que os profissionais mais maduros, tal condição pode ser modificada com a consolidação de sua profissionalização. Os advogados que começaram a carreira tardiamente encontram dificuldades que se perpetuam mais para eles do que para os que ingressaram no campo, numa faixa etária considerada padrão.

\section{Os funcionários judiciais}

Entrevistamos sete funcionários, sendo dois auxiliares judiciários, um escrevente-chefe, um escrevente, um diretor de cartório e dois oficiais de justiça. Como no caso dos advogados, a amostra não tem objetivo de representação proporcional, tendo sido escolhida para ilustrar as atividades desempenhadas no cartório e na vara. Dos entrevistados, duas informantes são do sexo feminino.

Apenas um deles não cursou Direito. Era formado em Ciências Sociais pela UNESP e havia sido professor de OSPB e de Moral e Cívica, entre 1973 e 1979, na rede particular e depois na rede estadual de ensino de um município perto de Branca, antes de ser chamado para ocupar a função de oficial de justiça. Os demais entrevistados cursaram ou estavam cursando a Faculdade de Direito de Branca.

Há uma predominância de entrevistados na casa dos 25 anos, e dois entre 35 e 45 anos de idade. As perspectivas profissionais para estas duas faixas etárias são distintas. Em geral, os mais moços pensam em realizar concursos para as outras carreiras, como a Magistratura e o Ministério Público, enquanto os mais velhos pretendem seguir no Fórum. A carreira mais valorizada é a de juiz, seguida pela de promotor e de procurador.

A origem social dos informantes é bem típica da classe média, com a predominância de vínculos com o serviço público ou com o mundo do Direito seja por parte do pai ou da mãe. Assim, quando o pai era de origem social mais baixa, a mãe era funcionária pública ou professora. Este é o caso dos dois informantes mais velhos. Um deles era filho de um barbeiro e o outro de um alfaiate. Na geração mais jovem, os pais tinham ocupações como as de funcionário público, advogado, corretor, viajante e professor. 
Apenas duas mães eram donas de casa. Duas tinham a ocupação de funcionária pública, sendo uma formada em Direito, trabalhando em cartório e três outras eram professoras.

Alguns deles são de Branca ou de cidades da região. Embora haja também mobilidade geográfica na amostra entrevistada, ela é menor do que a observada entre juízes e promotores e foi toda feita dentro do próprio estado de São Paulo, como é o caso da amostra de advogados.

O ingresso na Comarca Branca se deu através de concurso para escrevente ou auxiliar judiciário. Os que tinham cargos de chefia obtiveram essas promoções internamente. Elas são vinculadas ao juiz da vara que escolhe seus critérios de seleção. Assim, alguns juízes podem optar pela promoção por antiguidade, outros por mérito, por confiança, por uma composição destas qualidades. Como os cargos de chefia são de confiança, os escreventes podem ser substituídos por outros, mas as carreiras administrativas têm um prosseguimento, já que são desempenhadas na estrutura do Judiciário, um ambiente onde o juiz tem a garantia da vitaliciedade e o funcionário é um servidor público.

\section{A competição interprofissional}

A competição interprofissional no mundo do Direito se destaca quando focalizamos a interação dessas profissões na Comarca Branca, revelando como ela é condicionada pela posição que o profissional ocupa neste universo. É esta interdependência de todos os papéis profissionais que estrutura a disputa por enfoques, perspectivas, privilégios, monopólios sobre objetos, campo de atuação e poder de decisão. Os conflitos são decorrentes da existência objetiva de diferentes lugares no sistema das profissões. Observa-se inclusive a mudança de opinião em profissionais que focalizavam determinada questão sob um ponto de vista e passam a aderir a outro, tanto em decorrência da mudança efetiva do lugar ocupado no mundo do Direito quanto da visualização desta oportunidade, antecipando a nova conduta para favorecer a redefinição da identidade profissional e a socialização neste outro contexto ${ }^{5}$. Assim, a opinião de um juiz que passa a

\footnotetext{
${ }^{5}$ Sobre a mobilidade social e as mudanças de conduta, com indivíduos aderindo aos valores do grupo onde deseja ingressar, ver estudos sobre grupos de referência e socialização
} antecipatória realizados por Lipset e Bendix (1963)
38 ser advogado ou de um delegado que vira promotor público sofre redefiniçõos em função desta nova posição de onde passa a interagir no campo da justiça.

Os conflitos profissionais apontam para a existência de maior tensão entre aqueles que estão em posições de fronteira, reforçando a noção de que é a proximidade nos lugares ocupados no mundo do Direito que aumenta a disputa entre eles. É possível detectar a distância entre as posições profissionais, em função da forma mais amena, mais cordial ou mais externa com que os entrevistados se referem às profissões que atuam neste campo. Ela é observada principalmente na hierarquia ocupacional. O contato entre auxiliares judiciais e juízes é espacialmente próximo, mas é socialmente distante. As questões que provocam a manifestação de opiniões mais veementes e conflituosas são aquelas cuja proximidade profissional as coloca em disputa, seja legalmente, seja negando-lhe a aceitação desejada através da contestação contínua.

Os casos de competição interprofissional identificados com mais frequência na amostra têm uma direcionalidade na hierarquia das profissões que reproduz a da estrutura social: são os imediatamente inferiores, seja em poder ou em prestígio social, que mais colocam em questão as posições dos que estão próximos, mas num patamar acima nesta escala de força profissional e institucional.

Neste sentido, são os juízes que ocupam o topo da estratificação interna do mundo do Direito na Comarca Branca, e os depoimentos coligidos reforçam esta percepção. Eles não têm muito presentes em suas preocupações as formas como são percebidos pelos demais membros do campo judicial, mas voltam suas criticas mais para o Poder Legislativo e/ou para Poder Executivo, dependendo dos conflitos que estão enfrentando em cada conjuntura. No momento da realização das entrevistas havia grande tensão dos magistrados com os deputados, porque estava em pauta no Congresso Federal a discussão sobre o controle externo do Poder Judiciário. O problema das relações desses profissionais com o Poder Legislativo será focalizado mais adiante.

As competições interprofissionais observadas foram entre os promotores e os juízes, entre os advogados e os juízes, entre os delegados de polícia e os promotores e entre os funcionários de cartório e os advogados. Os promotores comentavam com sarcasmo a característica 
passiva da Magistratura. Nesta linha, se juntavam os advogados, acrescentando a crítica que procurava acentuar o aspecto de funcionário público acomodado, moroso e despreparado, às carreiras do Poder Judiciário. Os delegados de polícia manifestaram sua 'irritação' com os membros do Ministério Público e com as conquistas mais recentes desse grupo, que aumentaram inclusive o poder dos promotores sobre os delegados. Os funcionários de cartório concentraram sua artilharia contra os advogados, caracterizando alguns como desconhecedores dos trâmites legais. Em geral, estes funcionários são bacharéis em Direito.

Exemplos da competição interprofissional com esta direcionalidade, dos imediatamente abaixo para os que estão logo acima, são reproduzidas a seguir.

Depoimentos de promotores públicos a respeito da Magistratura:

Eu prestei concurso para o Ministério Público e a Magistratura e fui aprovado nos dois... Fiz opção pelo Ministério Público por diversos fatores: em $1^{\circ}$ lugar porque o MP não tem funcionários subalternos. $\mathrm{O}$ promotor é aquele que exerce sua atividade sozinho. Todo o trabalho que tem que ser realizado é por ele efetuado e por mais ninguém. Então, não existe aquela preocupação de policiar o desempenho dos funcionários; em $2^{\circ}$ lugar, porque o promotor é um fiscal da lei, ele não é uni órgão inerte. Ele tem sempre que estar efetuando atividades para que o juiz possa julgar; em $3^{\circ}$ lugar, entre promotor e juiz não existe nenhuma diferenciação nos vencimentos, nas garantias, nas carreiras e o promotor tem um amplo campo de atividade. Dai, então, ter me interessado pela carreira no Ministério Público. E também tem mais um porém: eu gosto muito de atuar no Tribunal do Júri e como juiz eu não teria essa opção, uma vez que o juiz tão somente preside os trabalhos. Dai minha escolha pelo Ministério Público.

Entre promotores e juízes há uma recíproca fiscalização. Toda conduta que eu faço vai para apreciação do judiciário. Passa pelo crivo do juiz, que se discordar, achar que o crime era de vulto relativamente grave e não deveria conceder remissão, ele deve expor as razões dele e remeter ao procurador geral, que funciona como o chefe do Ministério Público. Se ele achar que o juiz tem razão, ele pode designar outro promotor para tomar aquela providência que o juiz achava que eu devia ter tomado. A mesma coisa acontece com as decisões judiciais. Eu tomo ciência e se não concordar com a medida que o juiz adotou, eu recorro ao Tribunal, que funciona como o órgão superior ao juiz de primeiro grau, ele pode reformar aquela decisão do juiz e aplicar a medida que eu postulei. Então, há realmente, um sistema de freios e contrapesos. Eu diria que existe uma fiscalização recíproca entre ambos.

Depoimentos de advogados sobre a Magistratura:

Eu entendo que o controle externo da Magistratura é importante... Quando a Ordem defende este controle, eles não estão simplesmente entendendo que a sociedade como um todo deve participar do conjunto de medidas que regem o judiciário com maior transparência... A sociedade tem que tomar conhecimento. Afinal de contas, é o Estado que paga, é a sociedade que paga. Ela tem que saber como ela está pagando e por que... O controle externo seria por uma maior tramitação da justiça, melhor funcionamento dos cartórios e questão de prazo.

O juiz, talvez por imposição do acervo de serviços, dos trabalhos que ele tem, não tem tempo suficiente para se dedicar ao estudo, que o advogado devota, para demonstrar a inconstitucionalidade de determinados artigos constitucionais. Isto nos traz uma mágoa profunda, porque eu acho que é aquela contingência humana de juízes e promotores, que não estudam ou de delegados que estudam menos ainda.

Eu nunca prestei concurso algum, nunca pensei, nunca quis, mesmo porque não existe nada mais gratificante que ser advogado. A maioria dos juízes e promotores são idealistas, mas quando eles se aposentam, a primeira coisa que eles querem é se inscrever no quadro da Ordem e dizer 'sou advogado'. Eu jamais prestei concurso algum e jamais vou prestar, porque eu me realizo como advogado.

O juiz, geralmente, o magistrado, ele fica bitolado. Ele não tem as janelas abertas para a vida, ele fica bitolado dentro da lei e dentro da jurisprudência. Ele fica como um autômato diante dessas circunstâncias da jurisprudência e da lei, da aplicação da lei e da jurisprudência do Tribunal, que valem mais do que as próprias leis objetivas: penal, processual, cível, comercial, todos os ramos da advocacia. São intermináveis.

Nós nos ressentimos, por exemplo, de magistrados moços que nem sempre estudam aquilo que deveriam estudar para se definirem diante do advogado e diante da sociedade. Haja visto aquela fábula já do velho La Fontaine, que diz: 'Juiz que não estuda ou que não sabe, a toga se saúda...' 
Embora eu tenha sido um juiz, eu acho que a Magistratura tem que trabalhar limpidamente, como acontece no estado de São Paulo. Não existe nada que se faça, que não seja assim, visto pelos advogados, pelos promotores. Eu acho que tem que ter o controle externo da Magistratura. Seria o melhor para o juiz. Os juízes iriam se sentir até bem, sabendo que estão vendo o trabalho...

Depoimentos de delegados de polícia sobre os promotores públicos:

Os delegados não são, assim, um grupo tão unido. Tem a sua união, mas é uma união um tanto quanto frágil. Tanto que as reivindicações da categoria raramente são aceitas e cada ano que passa a carreira está perdendo mais apoio e mais prestígio e mais força de trabalho, tendo em vista justamente a falta de união. Nós podemos traçar um parâmetro com o MP, por exemplo, os delegados de polícia e os promotores. Você retornando dez, quinze anos atrás e comparando a força de um delegado de polícia com a força de um promotor público, não existia termo de comparação. $\mathrm{O}$ delegado era muito mais forte, tinha mais força, muito mais poder. Era muito mais atuante do que um promotor público, que sempre ficava ali, à margem. Mas a união do MP é muito poderosa. Eles são uma classe muito unida, tanto que hoje se equiparam financeiramente aos juízes e passaram a léguas de distância os delegados de polícia em termos de poder, de força, de prestigio.

Existem grupos radicais entre promotores e até entre juízes, no sentido de adquirir a subordinação da Polícia Judiciária a eles. Mas desde o início do Código do Processo Penal que existe o inquérito policial e ele é presidido pelo delegado, que é bacharel em Direito, igual ao promotor e ao juiz. Então, não tem que existir vinculação hierárquica, nem administrativa, nem judiciária. Eu acho que tem que haver uma conjugação entre as três atividades e o delegado ser reconhecido como realmente é: um bacharel em Direito, igual ao juiz e igual ao promotor. A faculdade que nós fazemos é igual à faculdade que eles fazem. Não existe bacharel de segunda ou primeira categoria, nem sangue azul ou sangue verde; todos são iguais. Existem grupos radicais entre juízes e promotores que entendem que a polícia deve ser subordinada a eles...

O Ministério Público está querendo um espaço maior dentro do contexto jurídico e administrativo do Estado. Então, eles estão aumentando a quantidade de promotores, estão criando cargos e já existem cargos que não existiam. Eles estão tendo condições de fazer mais denúncias, de participar mais. Só que isso em parte é bom e em parte é ruim. Eles querem realmente segurar uma parte do poder para eles. Querem, todo mundo sabe, ser o quarto poder. Tem o Poder Executivo, o Legislativo e o Judiciário e eles querem ter o poder do MP, que em alguns países existe. Esse $4^{\circ}$ poder, eles gostariam no Brasil... Então, esta mudança que está ocorrendo na sistemática toda, com essa atuação ou ingerência do MP no processo jurídico, precisa haver uma contrapartida para que não sobrecarregue o judiciário e nem desfavoreça a polícia. Seria a questão de se pensar numa outra sistemática para a polícia, por exemplo, um juizado de instrução, como existe em outros países. O delegado é um juiz de instrução. Ele julga causas pequenas, uma lesão leve, alguma coisa assim que seria julgada pelo delegado. Em contrapartida, ao invés deles aumentarem o poder da polícia, ele tem sido diminuído. Então, nós perdemos o mandato de busca na Constituição de 1988. Hoje, a polícia não pode mais entrar numa casa, às vezes, sabendo que tem produto de furto lá. Não posso entrar para apreender. Eu tenho que pedir um mandato de busca para o juiz. Se é um fim de semana, não há um plantão judiciário, o promotor às vezes não é da Comarca. Não se localiza o promotor para opinar pelo mandato de busca e o juiz, às vezes, não concede porque o promotor não opinou. Eles tiraram uma forma de trabalho e não deram uma outra que pudesse suprir aquela. Por outro lado, nós tínhamos antes da Constituição de 1988, e não se sabe se foi revogado, mas, por ingerência também do M.R, foi retirado da polícia, um procedimento que chamava judicialiforme, que era um procedimento dos processos contravencionais. Então, em caso de contravenção, que é porte de arma, direção perigosa, direção não habilitada, que são crimes menores, o processo já era começado na delegacia, não era um inquérito. Eles cortaram esse procedimento entendendo que o promotor é dono da ação penal. Para a polícia facilitou, porque diminuiu o serviço, mas nós perdemos mais o nosso poder. O delegado fazia uma audiência com o escrivão, o advogado, as partes, como é feito hoje numa audiência no Fórum e este termo já ia para o Fórum, o processo já formado. O promotor se manifestava e o juiz já podia decidir em cima disso. Hoje não. Uma pequena contravenção, o delegado obtém as provas, instaura o inquérito, manda para o promotor fazer a denúncia, o juiz vai refazer todas as provas, ouvir réus, novamente, testemunhas, para depois julgar. Então, veja bem o que um pequeno artigo da Constituição às vezes faz na sistemática. Aumentou muito mais a quantidade de processos e audiências no Fórum na parte criminal também. 
Depoimento de um delegado de polícia que estava prestando concurso para o Ministério Público, ilustrando o processo de mudança de valores profissionais, como uma antecipação que favorece a passagem de uma carreira a outra:

A minha experiência pessoal, com o MP, com toda a sinceridade, é a melhor possível. Eu tenho o maior respeito pelos promotores, inclusive estou prestando concurso para o MP, uma questão de foro intimo. Tenho o melhor relacionamento possível na minha cidade e onde eu passei, tenho grandes amigos promotores. Nunca tive um problema sequer. Admiro a instituição, acho maravilhosa e não tenho nada a dizer, porque, realmente, eu nunca tive problema com eles, onde eu passei ... Quanto à atribuição de poderes, os próprios direitos e garantias dos membros do MP, foram ampliados na Constituição de 88. Tem muito mais condição de atuar, porque o MP é , na verdade, o fiscal da lei. Então, ele não simplesmente condena alguém. Ele pede a condenação como também pede a absolvição, se for o caso. Isto que é bonito no MR. Ele é o fiscal da lei, ele vai zelar pela aplicação da lei. Ele não tem nada a ver se a pessoa está certa ou errada, ele quer mostrar que a lei vai ser aplicada. Então, eu acho bonito nessa parte aí. Acho maravilhoso. É uma instituição nota 10.

Depoimento de funcionários de cartório sobre advogados e promotores públicos:

Tem advogado, às vezes, recém-formado que é difícil a gente trabalhar. Âs vezes, vem fazer pergunta para o escrevente, ver como que funciona um processo... Então, isso tem uma certa influência. Também deveria ser mais rígido o controle da seleção... É o advogado que tem que saber como funciona um processo e não o escrevente. Então, isso dificulta a gente...

Quem manda, quem determina, quem dá as ordens no cartório é o juiz de Direito. Quer dizer, não é o promotor. O promotor vai requerer por escrito. Se tiver que tomar alguma medida, é o juiz. É isso que acontece via de regra. O promotor não manda. Quem determina é o juiz corregedor. O promotor pode requerer alguma coisa, para que o juiz tome essa medida. Ai, sim, se o juiz entender que a medida deve ser tomada, ela vai ser feita. Mas diretamente, nós não estamos ligados ao promotor.
Se há uma competição interprofissional partindo daqueles que estão em posições próximas, mas inferiores, que é alimentada pelos valores dominantes na estrutura social brasileira, há a perspectiva inversa, embora ela seja registrada em menor grau. A reação daqueles que estão nas posições superiores se manifesta quando seus competidores conseguem representar ameaças, dada alguma vulnerabilidade, algum ponto sensível que evidencia a fragilidade da posição superior, em relação ao competidor. Desta forma, aquela profissão que pretende conquistar mais força corporativa para a sua atividade ajuda a difundir uma imagem pública negativa dos que ocupam a posição mais cobiçada. A competição interprofissional se processa mais intensamente nos dois sentidos quando há possibilidades concretas de ameaças. Nestes casos, ela é observada em todas as profissões envolvidas na competição, tanto de baixo para cima quanto de cima para baixo na hierarquia profissional. $\mathrm{O}$ que a caracteriza e dá origem é a proximidade das posições ocupadas, e o que a intensifica é a possibilidade de conquistar novas áreas de domínio profissional.

Assim, ela pode ser observada nos depoimentos dos entrevistados, em situação inversa da verificada acima, partindo agora dos que estão em posições superiores referindo-se aos que, embora estejam ocupando posições inferiores, estão muito próximos ou estão em situação cujas questões que são objeto de disputa ainda não se transformaram em conquistas monopolizadas por nenhum dos competidores.

Entre os juízes e os promotores registrou-se uma competição maior partindo destes últimos para os primeiros. Uma parte dos juízes entrevistados sequer identificava a pressão e a ameaça vinda dos promotores. Seus olhos estavam principalmente voltados para o problema com o Legislativo, para a discussão sobre controle externo do Poder Judiciário e as acusações de morosidade. Apesar disto, registramos intensas reações às ameaças que a nova posição do Ministério Público poderia representar, colocando para os juízes a necessidade de reforçar a distinção e a superioridade de sua função.

Situação semelhante foi observada na reação dos magistrados às visões dos advogados sobre o Poder Judiciário, que enfrentou o tensionamento da competição interprofissional na questão do controle externo do Judiciário e da obrigatoriedade ou não da presença de advogados nos processos encaminhados aos Juizados Especiais de Pequenas Causas. 
Depoimentos de juízes sobre promotores:

A atuação do Ministério Público é, na minha opinião, importantíssima... com as diversas atribuições previstas na Constituição, a sociedade mais e mais vem sendo protegida pelos membros da instituição..

Os promotores de um modo geral, também eles encontram dificuldades de ordem material, como nós juízes e acredito que, pelo menos aqui, o relacionamento de promotores e juízes é excelente.

Falar da carreira do outro é um negócio... Eu não gostaria de falar muito. Eu acho o Ministério Público uma carreira independente... Eu acho que é uma carreira para a qual poderia ser atribuída mais algumas situações, embora o MP tem sido curador do meio-ambiente, de um monte de situações ... Eu não vou entrar a fundo naquilo que eu acho pessoalmente porque é até deselegante falar da carreira do outro. Acho que o MP, ter uma estrutura, uma reforma, alguma outra situação que dê outro caminho para o MP. Não só ficar aí, além de propor a ação penal, ter uma atividade mais direta junto ao processo em si. Para o MP ter uma ação mais direta nos processos da polícia, ser até mais atrelado à polícia no aspecto penal. Não ficar simplesmente aguardando o que o delegado faz, para depois dar a sequencia. O MP tem que participar mais direto das investigações, atingir mais o investigado. ... Agora, no Brasil, o MP fica esperando, embora podendo pedir diligências, fica esperando, esperando acontecer...

O Ministério Público que tem que provocar. Só basta lembrar que com toda essa barbaridade que nós ouvimos do Congresso (episódio Ibsen Pinheiro, escândalos de corrupção) não é de agora que o Ministério Público Federal não se manifestou, não tomou iniciativa. Não precisa esperar a CPI acabar. A medida em que iam surgindo os fatos, o Ministério Público Federal já deveria ter agido, sequestrando bens, colocando em disponibilidade, porque é questão política. $\mathrm{O}$ Ministério Público é um órgão político. Ele não faz parte do Poder Judiciário, ele é do Executivo. O Aristides Junqueira é uma menção, um ad nutum, admissível, um apenadinho ao Presidente. Por isso que eles querem o controle externo...

O Ministério Público, na minha opinião, é um poder que atrapalha. Ele não faz nada, atrapalha. Houve um tempo que não existia MP. Os advogados eram nomeados pelos juízes. Isso nos anos 20,30 e ofereciam denúncias nas versões penais e o processo funcionava tão bem, ou melhor, que hoje. De forma que, minha opinião sobre o MP não é muito interessante... Mas, o que eu questiono em relação ao
MP é a finalidade da instituição. Agora, evidentemente que existem homens de bem e valor no MP. O que eu não concordo é com a instituição em si, da forma que ela está sendo levada e conduzida hoje, como também existe o Ibsen Pinheiro, que é promotor público. Ele ganhou um apartamento onde ele mora e não sabe de onde veio.. Eles querem sob todos os aspectos se transformar no $4^{\circ}$ poder. Eles querem chegar ao lugar do juiz, sem serem juízes e isso é ruim para o povo. O que o povo precisaria, no meu modo de ver, seria um MP que fosse atuante dentro de sua função especifica que era a proteção do interesse coletivo.

Depoimentos de magistrados sobre os advogados:

... O advogado hoje, infelizmente, eu acho que, como em todas as carreiras, o nível caiu muito, o nível do ensino caiu muito. Então, não é uma questão de péssimos advogados. Eu acho que existem péssimos médicos, dentistas, enfim, acho que toda profissão, toda carreira hoje, não sei se as pessoas chegam muito fácil ou se proliferaram as faculdades. Isso faz com que aumente o número de profissionais em cada área, então há uma perda da preparação. Eu acho, como em todas as carreiras, há um decréscimo da formação profissional. Infelizmente nós temos visto trabalhos ruins porque os novos não estão bem preparados. Os advogados antigos, a gente percebe que eles se formavam com outro conteúdo, com outro preparo. Hoje não. O advogado se forma, pensa que é advogado, vai advogar e o trabalho dele eu acho que é um trabalho muito difícil de executar. Às vezes parece fácil na prática, que ele se formando e tendo uma máquina de escrever ele pode peticionar, mas o trabalho que o advogado faz fica escrito, e qualquer um pode vir e examinar as falhas profissionais... Se o advogado move uma ação ruim, fica escrito. Ninguém vai conseguir apurar que o médico errou na sala de cirurgia, ao passo que outro profissional da mesma área vai verificar que o advogado errou naquele processo, entrou com a ação errada... A advocacia é uma profissão difícil de exercer porque aquilo que a gente escreve fica arquivado e amanhã, qualquer um pode chegar e ver o erro, a imbecilidade do advogado em questão. Então, é muito difícil no dia a dia.

A lei não prevê a necessidade de advogado assistindo as partes (nos Juizados Especiais de Pequenas Causas). Essa questão é objeto de discussão. Há uma ação em andamento no STF. Ainda não há uma solução definitiva sobre o assunto. 
... A lei diz que não é necessário advogado. A lei que criou os Juizados Especiais de Pequenas Causas diz que não é, mas sempre é interessante. Veja bem, não é necessário, mas também não é vedado. Aquela parte que entender necessária a assistência de advogado deve solicitar a presença de um, se ela se sente mais segura. Ainda que ela não possa custear os honorários, ela pode pleitear a indicação de um advogado. Há um convênio firmado entre a OAB e a Secretaria de Justiça. É indiferente tanto a presença quanto a ausência (de advogado), para efeito de processamento da reclamação.

Depoimentos de promotores públicos sobre os delegados de polícia:

A polícia, eu acho que ela é um pouco lenta, ela tem retardado um pouco as investigações, mas decorrente do próprio excesso de trabalho. Se lá existe lentidão, aqui já existe uma pressa bem maior. $\mathrm{Na}$ polícia existe corrupção principalmente nos grandes centros. É preciso haver um controle muito grande para evitar a corrupção. $\mathrm{Na}$ Magistratura a corrupção é coisa raríssima, então, na polícia é mais comum, infelizmente. O grande problema da polícia é esse daí: corrupção. Mas, não generalizando, dizendo que todos são corruptos, mas é preciso um controle bem grande, porque eles estão trabalhando numa atividade que é muito propícia.

\section{O conflito com o Poder Legislativo}

As tensões com Legislativo e/ou com o Executivo delimitam as fronteiras do mundo do Direito. Elas variam dependendo do momento político e de qual desses dois poderes está à frente dos conflitos com os profissionais do Direito. Em 1994, quando coletamos os depoimentos, predominava a resistência coletiva às críticas provenientes do Congresso, unificando o campo em torno do Judiciário. Os entrevistados manifestavam seu descontentamento com os deputados, principalmente no que se refere ao estado da legislação, das leis processuais, consideradas ultrapassadas e inadequadas para o andamento eficaz do sistema judiciário. A reação dos magistrados a esta situação refletiu o lugar de onde eles interagiram com os deputados, partindo de uma posição no topo da hierarquia dessas profissões, mas com menos recursos de poder frente ao Legislativo naquele contexto. Dando consistência à concepção de mundo do Direito, os promotores, advogados, delegados de polícia e funcionários de cartório se juntaram aos magistrados identificando as acusações de morosidade da justiça como responsabilidade do Poder Legislativo e dos instrumentos legais que eles colocavam à disposição do Judiciário. São estas situações de coesão que revelam como eles se constituem num universo específico, com autonomia relativa e dinâmica própria, gestadas na interdependência das competições profissionais, que impulsionam suas disputas e sua socialização nos valores da ordem jurídica.

Depoimentos de magistrados referindo-se ao Poder Legislativo:

A questão da morosidade depende muito mais de uma legislação adequada do que do trabalho propriamente do juiz..

Eu acho que tudo é uma questão de legislação, volto a repetir, uma legislação mais moderna, menos formal, fará com que o andamento dos processos seja mais rápido.

Acredito que muitos processos têm uma tramitação muito morosa que é por força da própria legislação que é ultrapassada. Quem faz lei é o deputado e o senador. Nós trabalhamos com o instrumental legal que temos à disposição..

Nós não temos uma legislação que, efetivamente, venha a solucionar os problemas do povo na prestação jurisdicional Precisamos reformular completamente as nossas leis e fazer leis que sejam adequadas à realidade do Brasil... Mas, parece que os nossos legisladores não querem leis boas, que, eventualmente, se voltariam contra eles...

É discutível que um deputado que possa estar com processo de cassação esteja fazendo a fiscalização do Judiciário. A questão é saber qual legitimidade, qual moral teria essa pessoa... Então, embora eu não seja contra esse controle (controle externo do Poder Judiciário), eu sou contra a forma que está se pretendendo criá-lo, talvez até como instrumento de pressão política.

Um dos arautos do controle externo é o Ibsen Pinheiro. Ele é promotor de justiça..., ele que propunha o controle externo, inclusive em questão jurisdicional e você viu o que aconteceu com ele. Ele não explicou a origem de seu dinheiro.

O controle externo do judiciário eu sou frontalmente contrário. É uma forma de submeter o Poder Judiciário à vontade dos poderosos, digo, da administração pública, porque o judiciário é o irmão mais pobre e mais fraco dos três poderes. Não tem verbas, não tem condições de trabalho, não tem nada. Tudo aquilo que existe no judiciário é com sacrifícios, num esforço terrível... 
As opiniões dos membros do Ministério Público sobre o Legislativo:

O problema que a gente encontra mais, às vezes, é um aperfeiçoamento legislativo. As leis nem sempre correspondem ao que a sociedade quer, principalmente na área criminal..

... uma parte dessa crise vem das leis processuais, que permitem muitas vezes recursos intermináveis. Então, as leis tinham que se aperfeiçoar no sentido que estamos presenciando agora com a criação dos Juizados de Pequenas Causas.

No tocante à morosidade da Justiça, isso é um problema legal, não é problema praticamente da Justiça, mas um problema de lei, onde existem prazos estipulados que devem ser observados. Além, obviamente, da necessidade do advogado, por exemplo, em obediência ao princípio do contraditório. Aí existe interesse do advogado em procacionar o andamento do feito. É isto que traz lentidão...

As opiniões de delegados de polícia a respeito da ação do Legislativo:

... no aspecto criminal, eu acho que se deveria atacar principalmente o sistema penitenciário, porque nós estamos atacando, o legislador está atacando o processo ao contrário. Em vez de procurar retirar da sociedade o delinquente e procurar recuperá-lo, eles estão investindo nesta parte e afrouxam as leis. Então, dá abertura dentro das leis penais para que o juiz e até o promotor pleiteiem a liberdade do delinquente sem ele estar recuperado. Até por pena da pessoa, de recolhê-lo a uma cadeia pública, a uma penitenciária, a uma casa de detenção, e isso prejudica a sociedade que é obrigada a conviver com o delinquente na rua e em alta rotatividade, porque o delinquente pratica o crime, é preso pela polícia, vai para a cadeia, passa por um estágio lá dentro para se aperfeiçoar e é solto pela justiça, porque a própria lei permite e o indivíduo volta para a sociedade para delinquir novamente... Então, eu acho que o sistema jurídico, os legisladores deveriam dinamizar as cadeias, as penitenciárias, aumentar o suficiente para acolher todos os delinquentes, inclusive os menores de idade, mas no sentido de recuperá-los, de educá-los, de fornecer trabalho para eles lá dentro como uma terapia ocupacional. Obrigar a cumprir a pena realmente e o sistema processual ser mais rígido, muito mais rápido. Está sendo ao contrário. Eles afrouxam é o sistema processual, que o indivíduo que é preso em flagrante hoje, amanhã ele é solto, não porque o juiz quer, não porque o promotor quer, porque o legislador fez a lei afrouxar o sistema processual.

O que a gente nota é o seguinte: o próprio problema do grande número de processos, aquilo que atravanca o serviço do juiz de Direito, que não é culpa da Magistratura. Eu acho que tudo isso vem vindo em decorrência do grande número de leis que existem. Porque ocorre o seguinte: o juiz tem uma determinada lei para aplicar, mas essa lei, indiretamente, tem uma outra lei ou outra anterior que favorece algum outro pedido. Então, tudo isso faz com que a aplicação da lei, ela se torne mais difícil. Então, você vê, po exemplo, chega numa parte em que o advogado de defesa pode apresentar as testemunhas de defesa numa coisinha corriqueira, um treco qualquer aí. $\mathrm{O}$ advogado pega e apresenta uma testemunha de Roraima e apresenta uma testemunha do Rio Grande do Sul. Você já viu quanto tempo leva uma Carta Precatória para ir para lá, para ser ouvido? Quando não, chega em Roraima, vem a Carta Precatória dizendo que a pessoa que morava em Roraima mudou-se para o Maranhão. Ao chegar aqui é expedida nova Precatória para o Maranhão. Só que a lei, ela já deixa expresso um determinado espaço de tempo até onde o crime prescreve, quer dizer: prescreveu, não se pode mais aplicar a legislação. Chegou até o final e está prescrito, tudo aquilo que foi feito, tudo aquilo lá caiu por terra... Agora, o número de leis é muito grande. Acontece um determinado tipo de coisa, cria-se uma lei, tem não sei o quê, tem outra lei. É alguma outra coisa, é outra lei. Só que ficam todas interligadas: o Código Penal tem validade, a Lei do Colarinho Branco tem validade, a Lei do Consumidor tem validade. Então, você vê que, às vezes, para você aplicar uma lei aqui tem algum outro artigo, outro dispositivo numa lei que não dá uma aplicação total dela aqui. Então, tudo isso vai atravancando a aplicação da lei..

Opiniões de advogados sobre a atuação dos legisladores:

O Poder Legislativo não legisla de acordo com o hodierno político, criminal, social. Eles, os nossos legisladores, que são deputados no âmbito federal, estadual e mesmo no âmbito municipal, têm dificuldades em elaborar leis com a perfeição que nós desejamos. Não existe essa perfeição. Existem muitos tropeços e muitas dificuldades que eles encontram e não têm o anteparo necessário para que as leis sejam mais céleres e mais consentâneas com a realidade da sociedade. 
Tudo gira em torno da legislação. O juiz tem que se ater à legislação, o promotor também, todos que trabalham na vida judiciária, eles têm um rito a observar e o rito é estabelecido por lei. Então, se o rito fosse simplificado seria melhor.

Opiniões de funcionários judiciais sobre a legislação:

Eu percebo que a morosidade não está, assim, nitidamente na Justiça em si, mas nas leis, porque as leis concebem prazos muito longos para determinado tipo de procedimento, dentro do andamento do processo. Os juízes, naturalmente, têm que respeitar as leis, os promotores também e eles fazem isso. Então, a morosidade não é deles na verdade, é própria das leis mesmo.

... a morosidade na justiça existe, mas eu acho que a culpa está na própria lei, na legislação. Não está no funcionário. O funcionário exerce sua função, trabalha, mas não está nele. É um problema de lei que estabelece prazos para isso, para aquilo.

... as pessoas aqui fazem o que podem. Tem pessoas que reclamam do Judiciário, mas a lei emperra muita coisa... Se a lei é falha, eles têm como escapar mesmo. Um maior rigor na lei consegue amenizar um pouco a morosidade... O sistema americano é diferente. O cara é preso e em 9 dias ele é julgado. Já é diferente do nosso, os nossos processos têm ritos diferentes. O nosso é assim e funciona desse jeito. Nós temos que nos enquadrar nesse sistema de andamento de processo...

As disputas entre o Poder Judiciário e o Poder Legislativo se aguçaram com a Constituição de 1988, já que este foi um momento de modificações na legislação e na distribuição de forças entre as instituições que atuam no campo da justiça no Brasil. Tal questão continua gerando tensão já que há propostas de alteração da Constituição. As possibilidades de mudança reacendem as disputas e a defesa dos interesses específicos das diversas instituições envolvidas com a questão da justiça, como a Magistratura, o Ministério Público, as Delegacias de Polícia, a OAB e os diferentes lobbies no Legislativo.

Embora o momento atual seja mais propício às tensões entre os dois poderes, por ser uma ocasião de disputa jurisdicional, a mudança na composição ocupacional dos membros do Congresso Nacional pode ter alguma influência no aumento da tensão entre o Poder Judiciário e o Legislativo. Esta hipótese, que requer investigação à parte, focaliza a diminuição no número de legisladores com formação em Direito como um fator capaz de intensificar os conflitos entre os dois poderes, mesmo sabendo-se que tais tensões se originam na esfera da política e da relação entre os poderes, questões que extrapolam a dinâmica profissional. Entretanto, uma bancada no Congresso com uma participação menor de advogados, que viveram uma socialização profissional e um treinamento ideológico nos valores do mundo do Direito, partilhando sentimentos comuns típicos do processo de formação profissional, pode atuar como tensionador e como diversificador desse corpo de legisladores, que experimentaram outras vias de socialização nas suas trajetórias anteriores ao ingresso no Parlamento.

A mudança na composição ocupacional dos membros da Câmara Federal é uma evidência de como este fator pode ajudar a tensionar as relações entre o Judiciário e o Legislativo, em momentos mais críticos desses embates institucionais. Na legislatura de 1967/1971, a Câmara Federal contava com uma participação de quase $50 \%$ de deputados com formação em Direito ${ }^{6}$. $\mathrm{Na}$ legislatura de 1991/1995 ${ }^{7}$, esta participação caiu para 1/3. A diversificação profisssional entre essas duas legislaturas materializa-se no total de profissões mencionadas, tendo a primeira cerca de 30 ocupações e a segunda 45. Além disto, observa-se um aumento na representação dos economistas, dos engenheiros e também de ocupações dos estratos sociais menos privilegiados para este último período.

\section{A competição intraprofissional}

Além das competições interprofissionais, o mundo do Direito engendra competições intraprofissionais, que se referem às disputas vivenciadas pelos pares, no interior da profissão a que pertencem. Cada uma das atividades ocupacionais (juízes, promotores, advogados, delegados de polícia e funcionários de cartório judicial) são estratificadas internamente, gerando inclusive segmentações, onde uma geração ou uma elite monopoliza os critérios de seleção de seus novos pares, multiplicando as disputas entre seus membros. $\mathrm{O}$ conceito de competição intraprofissional opõe-se à visão de profissão como um grupo com uma única identidade

${ }^{6}$ Dados extraídos de Deputados Brasileiros, 6a Legislatura, 1967/1971, Biblioteca da Câmara dos Deputados.

${ }^{7}$ Dados extraídos da Folha de S.Paulo, Caderno especial "Olho no voto", 18/9/1994. 
coletiva, além de enfatizar as mudanças internas que esta estrutura condiciona. Ele dá transparência às disputas em torno do poder de nomeação ${ }^{8}$, revelando o conteúdo ideológico das visões que tratam as profissões como corpos homogêneos, compartilhando valores comuns. Reconhecer os diferentes lugares existentes na hierarquia interna das profissões requer que se elimine a visão de que elas representam uma forma de organização comunitária, centrada numa identidade consensual. A identidade que predomina numa profissão é resultado do processo de instituição, que pressupõe a sua capacidade de dominar e se impor sobre outras.

As associações profissionais e os demais órgãos de classe enfatizam a construção desta identidade comum, mas a estrutura profissional se encarrega de minar tal percepção, gerando disputas e competições intraprofissionais. Essa situação foi observada em todas as ocupações investigadas nesta pesquisa. Aqui também a proximidade aumenta a tensão, porque facilita inclusive sua identificação. Há, na percepção dos profissionais, a sensação que sua atividade possui maiores dificuldades de agir como um grupo unido, identificando naqueles um pouco mais distantes, uma integração maior, uma ação coletiva mais eficaz, um sentimento de comunidade maior. Esta é uma característica decorrente da proximidade com que o profissional focaliza seu grupo e do distanciamento com que vê o outro. Assim, a perspectiva de sua visão é distinta num caso e noutro. Para o seu grupo de pertenci- mento, ele utiliza uma lente de aumento, já que o conhece por dentro. $\mathrm{O}$ grupo ao qual atribui um poder maior de organização e força é geralmente visto de fora, com menos conhecimento da situação interna, o que permite construir esta visão de maior coesão e poder. As lentes utilizadas para examinar ambas as situações têm capacidades distintas, alterando o resultado encontrado. A competição intraprofissional é detectada tanto nas profissões mais fortes quanto nas mais fracas, embora possa ter efeitos diferentes em cada uma delas.

O que garante a força profissional não se reduz a uma questão de integração e unidade. É necessário controlar outros fatores, como a seleção

\footnotetext{
${ }^{8}$ Bourdieu (1989) conceitua o poder de nomeação como as disputas para definir quem faz ou não parte de um grupo, incluindo tanto aqueles que têm força para instituir sua classificação quanto os excluídos, que questionam e não se submetem a essa rotulação. Sobre a teoria da rotulação e a sua aplicação semelhante ao poder de nomeação, ver Becker (1977).
}

do grupo, o monopólio do exercício profissional, a autonomia profissional, a capacidade de criar o problema que a profissão se propõe a solucionar, o controle do credenciamento, a titulação superior e a consequente organização de um conhecimento abstrato, que diferencie o possuidor deste titulo através da expertise. A conjugação desses fatores mostra-se muito mais eficaz para o poder profissional do que a perspectiva de união e identidade comum. estudada.

Vejamos como a competição se manifesta em cada profissão

\section{A Magistratura}

Entre os magistrados, tal competição foi identificada de duas formas. A primeira delas reflete uma tensão entre Primeira e Segunda Instâncias do Poder Judiciário, que se materializa nos cargos de juiz e desembargador, dois patamares da estrutura hierárquica da carreira, embora os juízes construam uma lógica para a profissão, onde ele se apresenta como independente e sem nenhuma autoridade acima da sua, já que tem plena autonomia para julgar. É na Primeira Instância que se julga um processo. A Segunda Instância é outro grau de jurisdição. Nela, julgam-se os recursos. O juiz deixa de judiciar nos processos e passa a julgar recursos de processos. Em todas as entrâncias da Primeira Instância, o juiz julga processos, ouve as partes, colhe testemunhas. Na Segunda Instância, os tribunais reavaliam a decisão do juiz, através do recurso, se a parte que não está satisfeita com a decisão assim desejar. Não cabe ao Tribunal fiscalizar o juiz de Primeira Instância. Este papel pode ser exercido pela Corregedoria Geral da Justiça e pelo Conselho Superior da Magistratura. Os juízes não possuem um chefe. Esta é uma das características da autonomia profissional e de sua força, mas um desembargador tem mais prestígio social e representa uma etapa acima na carreira da Magistratura. Essa tensão, quando captada nas entrevistas, aparecia como uma forma dos informantes referirem-se a alguma lentidão maior no andamento dos processos na Segunda Instância e não na Primeira Instância, onde eles atuavam.

Outra forma de competição registrada nas entrevistas auxilia a construção de uma imagem pública séria, competente, dedicada ao trabalho, com vocação para a carreira de juiz. Tal identidade faz contraponto com o comportamento daqueles magistrados que mais se assemelham ao lado 
negativo do funcionário público, que despacha o mínimo necessário para continuar sua trajetória, sem maiores problemas éticos ou de desempenho. Há alguma associação entre a trajetória profissional anterior ao ingresso na Magistratura e esta autoimagem, mas ela não pode ser reduzida a isto. Entre os que tiveram experiência na advocacia, a demarcação com o padrão funcionário público parece mais intensa do que entre os que fizeram sua carreira anterior apenas no cartório.

O juiz funcionário é uma construção do outro. É uma forma de usar o estereótipo para se diferenciar. É uma maneira de falar de si mesmo como ativo, dedicado, trabalhador, com uma carga diária de 12 horas de serviços, levando processo para casa nos fins de semana. Ninguém se identifica na posição do funcionário, que faz corpo mole no trabalho. Ela serve para reforçar a dedicação, a vocação, a competência, a melhor qualificação e o merecimento de tal posição profissional prestigiada.

Sou vocacionado para a Magistratura e enquanto advogado tinha o maior prazer em advogar, mas senti que era o momento de eu conseguir ser juiz... Todo juiz deveria, necessariamente, ser previamente advogado por um período de no mínimo cinco anos, com muita dedicação... O juiz, ele tem uma carga de serviço que vai muito além daquilo que seria o ideal. O juiz tem que trabalhar diariamente de 12 a 14 horas. Eu estou falando de juiz que trabalha. Não estou falando de alguns que, tem realmente uma exceção que não é muito ligada em trabalho, não é vocacionada e deveria estar em outro ramo, menos na Magistratura. Mas a maioria ainda é dada a trabalhar...

... Cada juiz é um juiz. Tem juiz que é mais rápido, tem juiz que é mais lento. Então, a morosidade eu acho, praticamente até contrariando a minha classe que sempre atribui essa morosidade a essa deficiência da justiça, da falta de verbas, falta de estrutura, falta de juiz, eu também acrescento uma coisa: há uma questão pessoal de cada juiz. Está certo que tem juiz que toca uma comarca normalmente e tem outro que é mais lento. Então, é uma questão de homem para homem, de pessoa para pessoa. A morosidade está em tudo, em todos os aspectos material e pessoal de cada juiz. $\mathrm{O}$ juiz tem que saber também o seguinte: nós não temos horário fixo de trabalho. Não assim, como qualquer cargo de indústria, que entra às $8 \mathrm{hs}$ e sai às 5 hs. $\mathrm{O}$ juiz tem que trabalhar fora de hora. Ele não consegue se a gente for trabalhar só naquele horário do fórum. Nós não temos condições de cumprir, então nós temos que trabalhar em casa, de madrugada, cedo, à tarde, à noite, sábado, domingo. Precisa haver essa disponibilidade do juiz. Não são todos que têm essa disponibilidade. Às vezes, por uma questão física ele não aguenta. Está certo, então há um atraso na sua vara, há um atraso no seu serviço. Há comarcas mais pesadas, outras mais acessíveis, mais brandas. Um juiz que pega uma comarca com 4.000 feitos, ele fica numa situação difícil para tocar. Outra comarca que tem um número menor de processos, ele tem condições de levar. O juiz que não se dispõe a trabalhar fora de hora, ele não vai conseguir agilizar a sua justiça... É uma questão de cada pessoa que é a diferença de um para o outro no dia a dia.

Eu penso e não só penso como tenho certeza na vivência desses 11 anos de Magistratura, dos juízes que vieram de uma carreira relativamente curta como advogado, eles sabem conduzir melhor os processos, sabem decidir melhor, têm mais sensibilidade, mais vivência e, principalmente, ele sabe olhar os dois lados. Ele sabe olhar o lado da Magistratura, do poder público, mas também sabe olhar o lado do advogado que, até por dispositivo legal, é um auxiliar da justiça. Ele não é um estranho. Essa interação entre Poder Judiciário e o advogado tem-se bem. É diferente de um juiz, por exemplo, que saiu dos quadros de funcionário do fórum, porque ele era funcionário e via de um modo geral o advogado como um adversário, porque para o funcionário o advogado que faz pedido de balcão, ele vê o advogado como adversário, alguém muito chato, que só enche o saco, aborrece, que só faz pedidos esdrúxulos. Enfim, quando ele entra, passa em concurso, ele continua mais ou menos com a mesma visão do advogado. Ele nunca foi advogado e se ele nunca exerceu a profissão, ele não sabe como funciona e não sabe o aperto do advogado em certas ocasiões... A minha experiência diz que, com algumas exceções, aqueles juízes que vieram dos quadros da advocacia são excelentes, são bons juízes. Aqueles outros que vieram da faculdade direto para a carreira por concurso ou vieram de cartório deixam a desejar um pouco, pelo menos no começo.

A experiência como cartorário me ajuda bastante, porque me facilita muito o contato com meus subordinados. Eu enquanto funcionário tinha a visão de um juiz enquanto administrador, enquanto quase que um gerente de Recursos Humanos, porque o juiz além da formação jurídica, ele tem a necessidade, ele exerce funções administrativas na comarca onde trabalha. Ele se relaciona diretamente com funcionário no cartório. A medida que eu crescia, eu também via a 
atuação de um juiz sob uma ótica crítica e imaginava como devia ser a atuação do juiz. Procurava tirar das atitudes do juiz meus ensinamentos e hoje, como juiz, eu procuro me relacionar com meus funcionários me colocando no lugar deles. Então, nesse ponto do relacionamento, eu já vejo uma vantagem que o aproveitamento das experiências do trabalho no cartório, os fatos que eu via acontecer nos cartórios, digamos que hoje não seriam uma novidade para nós, porque no meu trabalho no cartório eu tinha um contato com os processos. Nos diálogos com os juízes, os promotores e os advogados eu também aprendi na minha formação. Isso ajudou muito. Eu até considero que o ideal teria sido, mesmo para mim, também exercer a advocacia, porque é muito importante o juiz sentir o lado de todos que militam no processo, para que ele possa compreender com exatidão a preocupação das partes, dos advogados, dos promotores. Para que ele possa conhecer toda a estrutura que está ao redor do Poder Judiciário. Essa experiência da advocacia como a experiência do cartório chega a ser quase uma necessidade também para que a pessoa consiga se situar... (O informante era funcionário do fórum antes de ser aprovado no concurso para a Magistratura. Nunca exerceu a advocacia).

\section{As delegacias de polícia}

A competição intraprofissional detectada entre os delegados de polícia manifestou-se principalmente de quatro formas:

a) hierarquicamente, captada nas criticas à política de promoção. Neste caso, observamos criticas de delegados que ascenderam por tempo de serviço feitas aos que obtiveram promoção por merecimento. Há uma demarcação claramente negativa deste padrão de comportamento, associando os promovidos por mérito com a politicagem, o "puxasaquismo", enquanto a promoção por antiguidade obtém o reconhecimento legitimo neste grupo. A promoção por mérito aparece como um fator de ressentimento entre os que não galgam tais posições. Talvez eles estejam mais concentrados no interior do que na capital;

b) entre a geração formada a partir da democratização do pais e aqueles treinados no momento de repressão e associados aos governos militares. Os que demarcam mais esta diferença valorizam o trabalho baseado no conhecimento, no estudo das leis, em uma certa erudição, na imagem da delegacia como um lugar para ajudar a população em vez de ser temida por ela, uma instituição a ser procurada, capaz de atrair o cidadão;

c) entre os delegados com perfil mais operacional e os mais voltados para a atuação de rua, diferença pautada na experiência profissional anterior na delegacia, dada pelas atividades de escrivão e de investigador. De certo modo, esta forma de competição se interliga àquela das diferenças geracionais, com uma preferência pelo trabalho cartorário em detrimento do operacional, pelo menos nesta região do interior do estado e

d) uma demarcação da distinção entre a atuação do delegado no interior do estado e na capital. Procura-se construir uma relevância maior para o trabalho do interior diante da prioridade da capital sobre as cidades menores, fato que se verifica em quase todos os campos de atividade profissional.

Observamos também alguma tensão entre a delegacia da mulher e as demais. A informante deixou evidente que sua atividade é vista como algo menor, no interior da profissão, se comparada com as questões que são enfrentadas pelos delegados. A discriminação da mulher afeta a atividade da própria delegacia.

Existem dois modelos (de ascensão na carreira): primeiro, por antiguidade, e segundo, por merecimento. Por antiguidade, abrem-se as vagas. Os mais velhos, a metade dos candidatos vão por antiguidade. Então, os mais velhos vão subindo hierarquicamente. A outra metade é composta de puxa-sacos, maçanetas e outros puxas mais. Estou falando a verdade, só progridem desta forma os puxasacos, maçanetas e outras coisas mais. A minha (carreira) é efetivamente trabalhada, eu não estou na ala dos puxa-sacos, isto eu garanto.

Olha, eu costumo dizer que os delegados de polícia são muito desunidos, não são coesos. Eu acho que deveria haver um entrosamento maior, uma cooperação maior. Mas eu acho que dentro do possível, aquilo que no mínimo se espera, há. Porque é claro, é natural, eu acho que nem poderia ser diferente, que uma classe por mais que ela seja individualista sempre há um interesse comum, e quando há um interesse comum, há uma união. Mas eu diria que a classe dos delegados é coesa, é unida, tanto quanto são as demais carreiras. Eu acho que isto depende muito de cada pessoa, algumas pessoas são mais solidárias, mais companheiras, outras são mais 
individualistas. Mas existe também aquela coisa do interesse pessoal acima do interesse coletivo. E quando isso acontece, realmente, a classe toda sai prejudicada. Eu digo isso assim a nível de diretoria, de associação, cúpula da polícia, cargos da cúpula e tal. Quando é ocupado por alguém que está pensando apenas na sua ascensão, no seu bem-estar profissional, claro que o resto sai prejudicado. Vai depender do pessoal que está exercendo esses cargos no momento.

$\mathrm{Na}$ época de repressão, os direitos individuais quase sempre são esquecidos. Isso é óbvio, né? E hoje, a formação do delegado de polícia é completamente voltada justamente para respeitar os direitos individuais. Pode observar, hoje em dia, o delegado de polícia antes de autuar alguém em flagrante, ele toma muito cuidado antes de fazer isso aí. Antigamente não se pensava muito, certo? Então já se respeita. A Constituição indica vários direitos do cidadão, no caso que está sendo autuado, ou que está sendo acusado da prática de algum crime. Esses direitos todos são observados com presteza, sob pena de estar também incorrendo aí num abuso de autoridade, num abuso de poder, porque a própria lei hoje exige que seja assim. Não tem outro jeito. Nós não temos como trabalhar de forma diferente disso hoje. Temos que trabalhar em cima do que reza a Constituição e as leis. Já a Constituição daquela época é diferente. Hoje, a Constituição tem um rol de direitos inimagináveis... Hoje, um processo por abuso de poder ou de autoridade, com certeza, vai prejudicar a sua progressão na carreira, sem dúvida, mas não digo assim, abuso de poder ou de autoridade, mas um eventual engano, erro ou talvez abuso de um policial quando ele está em meio de uma ocorrência. Isso não é tão mal visto quanto um outro delito praticado contra o patrimônio, por exemplo, pelo funcionário público. Esse sim prejudica sobremaneira a vida funcional... Esses delitos (contra o patrimônio, corrupção, peculato) causam muito mais rejeição, é mais difícil de aceitar... A gente vê aí, um policial erra um tiro, acerta um cidadão ou então cometeu, digamos, na tentativa de levar a cabo uma missão, ele comete qualquer abuso contra a pessoa, no caso, integridade corporal da pessoa, mas na diligência, trabalhando. Isso não é um crime tão feio, tão horrível quanto um crime que versa sobre dinheiro, recebimento de pecúnia. Esse sim, não tem explicação óbvia para aquilo. Já uma agressão errada que ele comete pode ser justificável diante das circunstâncias. Ele vem até a ser condenado, mas para nível de tê-lo como um bom ou mal funcionário, isso aí pesa menos que um crime praticado por cupidez.
Na capital você é um lugar comum, você é uma pessoa, você não tem um destaque, você é um a mais na multidão. Você vai, você trabalha, você faz o seu plantão, volta para a sua casa e esquece que existe plantão, delegacia, polícia. Em São Paulo a realidade é essa. Você faz o seu plantão e volta para a sua casa. Os três dias para você ficar na sua casa, você vive a sua vida e procura na maioria dos casos, se eximir da vida policial e de coisas que estejam interligadas ao trabalho. No interior é completamente diferente. No interior você já não tem uma vida privada, com tanta liberdade. Você é mais vigiado, você é localizado com maior facilidade, você precisa estar sempre atento aos problemas da comunidade. Na capital você tem mais violência e mais liberdade. No interior você tem menos violência, em compensação você tem menos liberdade. Você é mais marcado. Você é uma pessoa destacada. Você tem que saber o que faz porque vai ter muita gente que vai estar te olhando... Agora, é claro, é muito mais fácil você subir por merecimento na capital, que existe muito mais casos de maior relevância do que no interior. As pessoas de maior destaque na sociedade moram geralmente nas capitais, nas cidades maiores. E um policial que resolve um caso envolvendo uma pessoa de maior destaque vai ter muito mais repercussão interna do que um outro delegado, que resolveu um caso de uma pessoa que não tem destaque na sociedade.

A única coisa que eu costumo reclamar é sobre a maneira que a administração encara a delegacia da mulher. Isto é uma coisa que às vezes me incomoda bastante. Embora eu ache que os colegas da administração façam tudo para que a gente não se sinta assim, eu acho que há uma discriminação por parte dos próprios colegas, por parte da administração. Alguns delegados tiveram inclusive muita dificuldade de aceitar a delegacia da mulher, a existência dela... Eu observo que algumas delegacias recebem muito mais reconhecimento, muito mais apoio. Aquela delegacia sempre tem maiores necessidades, ela é mais importante, ela precisa mais. Então, quanto ao trabalho da delegada, das funcionárias da delegada, é aquela coisa de que 'isso é uma bobagem qualquer, marido e mulher, sabe? Isso aí não dá, isso aí não tem peso social. Tanto mais, a mulher vai brigar a vida toda, a mulher vai apanhar sempre do marido, sempre, desde que o mundo é mundo isto acontece, sabe?' Inclusive e porque tirou dos distritos esse tipo de problema, porque ninguém quer atender, ninguém gosta de lidar com esses problemas e porque a delegacia da mulher tem uma função muito especial. Acho que a maior atividade da delegacia da mulher é a socia porque ela atende esse tipo de problema: familiar. Se envolve família é 
difícil você trabalhar e resolver alguma coisa. Eu acho que a delegacia da mulher deveria ter um aparato maior, inclusive com profissionais melhor preparadas, eu diria assim: uma assistente social, uma psicóloga que pudessem atender...

Tem diferenças positivas e negativas (entre o delegado que foi investigador e o que foi escrivão)... Geralmente o escrivão vai ser um bom delegado administrativo. Ele vai ser um delegado que toca inquéritos, que ouve pessoas, que mantém o inquérito policial de bom nível. O que foi investigador é o contrário. Ele vai ser um delegado atuante, um delegado de rua, um delegado que gosta de buscar bandido e fazer prisões, de detenções, mas vai ser um mal delegado administrativo, assim como o escrivão não vai ser necessariamente um bom delegado de rua, atuante.

O melhor para o delegado seria ter sido escrivão, porque o escrivão conhece o inquérito, conhece como proceder no cartório. O investigador não, o investigador trabalha na rua, faz mais serviço de rua. Então, é mais difícil para ele aprender como se manuseia o inquérito. Para mim, está sendo difícil isso... A imagem do delegado mudou. Mudou porque a população está muito descrente. Ela não acredita mais na polícia. Antes acreditava mais. Não sei se por imposição, não sei o porquê, mas ela acreditava mais na polícia... Os antigos tinham mais respaldo na lei, né? Hoje está muito difícil de trabalhar na polícia. Antigamente você falava: sou polícia. O cara te respeitava. Hoje dão risada e, certo? ... A lei dificultou um pouco não, ela dificultou totalmente, porque com a criação dos direitos humanos, não que não tenha que ter direitos humanos, mas os direitos humanos teriam que ser para todos e não só para os marginais... (Foi investigador por muitos anos em São Paulo. Ingressou como delegado dez anos depois de formado em Direito. Está no inicio da carreira, em Branca, e espera voltar para a capital).

\section{Os cartórios judiciais}

Observamos três padrões de competição intraprofissional entre os funcionários vinculados à Comarca Branca:

a) da parte de funcionários antigos em relação aos novos, demarcando sua experiência, sua relevância, seu esforço e sua superioridade e enfatizando a falta de conhecimento dos que chegam;

b) entre os auxiliares judiciários e os escreventes, onde os primeiros procuram reforçar sua qualificação ao desqualificar o cargo imediatamente superior e

c) entre as posições de chefia e os oficiais de justiça. A proximidade hierárquica dessas duas ocupações é que gera a possibilidade de disputa.

É justamente porque os oficiais de justiça não são subordinados aos diretores de cartório que se cria a oportunidade de uma disputa efetiva. A situação dos auxiliares judiciários em relação aos escreventes é semelhante, embora eles estejam um degrau abaixo do escrevente no organograma de cargos dos cartórios judiciais. Este lugar de fronteira inferior aparece no discurso dos auxiliares judiciários quando procuram descaracterizar alguma competência maior nos ocupantes das posições de escrevente. A negação da diferença evidencia uma estrutura hierárquica, na qual os auxiliares judiciários ocupam um patamar inferior ao dos escreventes.

... A crise do Judiciário que eu acho que poderia existir seria, por exemplo, uma parte diz respeito à admissão de funcionário. Seria muito mais rápido um funcionário aprender o serviço que ele faz, que ele irá fazer no caso, se ele soubesse na prática exatamente como lidar com um tipo de processo, quais são os procedimentos que ele vai ter que seguir e não existe isso. O funcionário faz uma prova de Português, conhecimentos gerais na área de Direito, Matemática e se for aprovado faz a datilografia que ele vai usar normalmente. Quando aprovado ele entra assim, sem saber nada do cartório. Ele só estudou, mas de procedimento processual não dá para ter noção. Então, seria legal que houvesse um curso, tipo dez dias ... Eu estou aqui há três anos, sou auxiliar. Eu lido com processo, mas há pouco tempo tinha um escrevente que estava lá há dois anos e não sabia absolutamente nada sobre o processo. Então, até que esse escrevente se adapte, aprenda como ele deve proceder em processo, já foi muito tempo. Tomar iniciativa, pegar um processo e realmente estudar, batalhar para ver como ele funciona. Ele não vai aprender, então, isso é falta de preparo para ver se a pessoa tem aptidão para exercer aquela função que nem sempre tem. As vezes, uma pessoa passa no concurso. Ele é ótimo, assim, por exemplo, como motorista do judiciário. Ele seria ótimo para cuidar dos serviços gerais, encanamento, essas coisas, mas não teria aptidão para mexer com processos. Tem um caso até, eu estava conversando com o diretor hoje, ele estava me explicando que duas pessoas que foram admitidas para trabalhar como escrevente, que não têm possibilidade de lidar Um era assim desequilibrado emocionalmente. Ele passou no 
concurso. Se surgisse um problema num processo, ele não saberia como resolver. Ele pediu exoneração do cargo. Não conseguiu se adaptar aqui. $\mathrm{O}$ outro, eles conseguiram fazer um arranjo interno e o colocaram para lidar com os serviços gerais que é o que ele mais sabia fazer e jamais conseguiria lidar com processo.

A função mais difícil eu acho que é a do escrevente. Ele tem que entender um pouco de tudo e o chefe vai fazer o serviço mais difícil e

o diretor tem que coordenar, vai ter que saber preparar, orientar... Precisa ter um bom Português, ser ágil numa máquina de escrever, acho que ter boa vontade, porque normalmente, quando as pessoas entram num cartório, elas estão muito mais querendo o salário e não por gostar da profissão propriamente dita.

A carreira de oficial de justiça é diferente de algumas outras carreiras, como por exemplo, da carreira de escrevente. A carreira de oficial de justiça não tem uma hierarquia. Não há, por exemplo, um oficial de justiça chefe, um oficial de justiça diretor, como acontece com a de escrevente. Então, o oficial de justiça é subordinado diretamente ao juiz da vara em que ele está lotado. Não há uma diferenciação de hierarquia dentro da carreira... O oficial de justiça, a grosso modo, ele é a extensão ou exteriorização daquilo que acontece, daquilo que é decidido, se infere, decorre, que se dá em audiência, decisões judiciais no fórum... Ele é a forma que o Judiciário tem de exatamente executar aquilo que foi determinado.

... O oficial de justiça não tem carreira. Ele começa como oficial de justiça e morre como oficial de justiça. A única coisa como referência é que de cinco em cinco anos, você ganha alguma coisa. Aos vinte anos você ganha a $6^{\mathrm{a}}$ parte, que demora dois, três anos para vir, mas não tem uma carreira assim, para ascensão. Você começou como oficial de justiça, o seu serviço é de rua e de cumprir mandatos na rua... Em termos de serviço, o tempo que você se dedica aos serviços é muito baixo: três, quatro horas por dia no máximo. Quer dizer que, nesse aspecto para quem é vagal, é uma delícia, para quem não quer ficar muito tempo trabalhando...

Ao mesmo tempo em que observamos, no decorrer desta pesquisa, como a proximidade na hierarquia ocupacional é causadora de tensão e disputa, verificamos que a distância nessa pirâmide profissional gera deferência social. Assim, embora os funcionários de cartório sejam os personagens mais presentes no cotidiano da Magistratura, são eles que ocupam a posição estrutural mais distante dos juízes, levando-se em conta seu lugar no mundo do
Direito. É da intensa socialização no fórum e desta posição claramente subordinada ao juiz que partem as avaliações e as opiniões de maior reverência ao prestígio e ao destaque do magistrado. A maneira como os magistrados são tratados internamente, nos cartórios, contribui para realimentar sua importância social. A formalidade do tratamento de Vossa Excelência extrapola o ambiente das audiências e se incorpora ao cotidiano do fórum com frequência, quando há uma plateia externa. Os funcionários judiciais são decisivos nesse processo de construção da deferência ao juiz, porque procuram obter para a sua posição profissional algo deste reconhecimento do público, deste temor, deste respeito. A condição de funcionário de escalão subalterno é reelaborada, para o público externo, pela criação de uma conduta de superioridade, de poder, que o funcionário incorpora à sua imagem, para caracterizar a forma como quer ser identificado. $\mathrm{O}$ fato de trabalhar vinculado ao terceiro poder da república acaba marcando o tratamento que destina à clientela, ao assumir para o seu cargo a condição de autoridade junto a quem precisa da justiça. Realimentar a deferência à Magistratura tem resultados práticos imediatos na própria percepção de sua valorização social ${ }^{9}$.

Não é por acaso que há competição intraprofissional entre os juízes que vieram da advocacia e aqueles provenientes dos cartórios judiciais. A simbologia em torno da carreira é mais acentuada no segundo grupo do que no primeiro. Os funcionários passaram muitos anos de sua vida profissional construindo tal distinção para a Magistratura e acreditam nela com mais empenho do que aqueles que viveram essa socialização em menor grau.

Outro aspecto que a abordagem da competição profissional ajuda a desnudar é que embora o mundo do Direito tenha sua autonomia relativa, há uma interdependência entre o sistema político e o sistema das profissões. Essas conexões ficam evidentes na tensão entre o Judiciário, o Legislativo e o Executivo no atual quadro político brasileiro e nas mudanças no prestígio da profissão de delegado de polícia. Assim, se há uma lógica própria das profissões, ela não está desconectada de outras esferas. Quando enfocamos a competição profissional no mercado de trabalho, percebemos como as mudanças tecnológicas são relevantes para alterar a condição de uma

${ }^{9}$ É possível que tal conduta seja mais acentuada em comarcas do interior e de regiões de médio e pequeno porte do que na capital. Entretanto, observamos mesmo nos Tribunais de Alçada, na Segunda Instância do Poder Judiciário, um padrão semelhante de lidar com o público externo, acentuando a distância e a autoridade da instituição sobre o cidadão. 
profissão nesta esfera. Assim, por exemplo, o fortalecimento da profissão de jornalista não pode ser desvinculado dos avanços obtidos pela mídia, em termos de tecnologia e de expansão do sistema de informação, além da eficácia dos lobbies dos jornalistas na Câmara Federal, para aprovação do monopólio do exercício profissional.

Também ao analisarmos o campo da justiça, as mudanças institucionais que detectamos, introduzindo novas funções para promotores e para os delegados de polícia aparecem como decorrência da democratização do sistema político no país. Na percepção dos delegados, tais mudanças trouxeram a perda de força e a difusão de uma imagem negativa da profissão, que foi mais valorizada e hoje sofre desprestígio junto ao poder público e perante a sociedade.

A democratização acompanhada da elaboração de uma nova Constituição deu mais destaque ao Legislativo em relação ao Judiciário. A força de um acabou por evidenciar a fragilidade do outro. Dos três poderes, hoje o Judiciário é aquele que mais precisa dos símbolos de prestígio e deferência sociais. A ênfase que os juízes têm dado à problemática da independência do Judiciário revela o temor da corporação diante de um cenário que identificam como de dependência, subjugados, desta vez, não pelo Executivo, mas pela forma como concebem o controle externo discutido no Legislativo.

\section{Conclusões}

Este trabalho focalizou a dinâmica do mundo do Direito na prática da Comarca Branca, uma comarca de médio porte, no interior do estado de São Paulo, dando uma dimensão concreta à concepção que lida com as profissões, como um espaço próprio com autonomia relativa.

Tal abordagem identifica a competição profissional como inerente a este universo. Assim, enfocamos a competição interprofissional entre juízes, promotores, delegados de polícia, advogados e funcionários de cartório na comarca selecionada, analisando a direcionalidade destas disputas e de que lugar neste campo os profissionais entrevistados interagiam.

Se a competição interprofissional torna perceptível as fronteiras neste espaço social, a análise da forma como o mundo do Direito se percebe em tensão com o Legislativo, no papel que este tem de elaborador das leis a serem aplicadas, revela o coesionamento dessas profissões nos valores da ordem jurídica, em prol de uma legislação mais técnica, menos permeada pelas contradições decorrentes de distintos interesses políticos. Tanto o limite das fronteiras quanto esta coesão dão corpo ao mundo do Direito.

A competição intraprofissional foi focalizada tomando como referência cada um dos grupos ocupacionais que interagiam na Comarca Branca para captar as formas como eles demarcavam internamente suas diferenças. Observamos como os entrevistados apresentavam um estereótipo da conduta profissional que desaprovavam, para se distinguir deste modelo e construir sua trajetória de uma forma positiva. Assim, a competição intraprofissional se manifestava na forma como os informantes desqualificavam o comportamento de 'pares', que pareciam fictícios, já que não é típico do universo profissional a autoidentificação de seus membros como inativos, morosos, incompetentes, corruptos, violentos ou apadrinhados.

Os depoimentos deram consistência ao mundo do Direito como um constructo analítico com fronteiras delimitadas tanto no mercado de trabalho quanto em relação ao Estado. Neste âmbito, as mudanças no papel institucional do Ministério Público, com a introdução da defesa dos direitos difusos e coletivos, a redefinição das atribuições dos delegados de polícia na ordem democrática, a discussão sobre o controle externo do Judiciário e sobre a obrigatoriedade ou não de advogados nos Juizados Especiais de Pequenas Causas revelam as interdependências do campo jurídico com o Poder Executivo e o Poder Legislativo. Ao mesmo tempo em que se constitui em um espaço social com autonomia relativa, as relações do mundo do Direito com o Estado limitam seus horizontes e geram simultaneamente novas oportunidades profissionais.

O contexto atual, marcado pela implementação da Constituição de 1988 e pelas disputas para viabilizar sua alteração através da revisão constitucional, reúne características relevantes para se compreender como se dá a interação das profissões com o Estado no Brasil. Ele permite também que se teste a adequação dos conceitos para o estudo dessas relações. Uma investigação mais aprofundada deste tema permitiria identificar se as mudanças que o mundo do Direito vive hoje são decorrentes de estímulos externos, provenientes de situações de poder exógenas, geradas no âmbito do Executivo ou do Legislativo, ou se tais questões entram na agenda política em decorrência da pressão de lobbies 
profissionais endógenos ao campo da justiça, como sustenta o modelo do sistema das profissões.

\section{Bibliografia}

ABEL, Richard L. (1989) American lawyers, N.Y., Oxford University Press.

Аввотт, Andrew. (1988) The system of professions: an essay on the division of expert labor, Chicago, The University of Chicago Press.

AdORnO, Sergio (org.). (1988) Os aprendizes do poder. RJ, Paz e Terra. (1994) Dossiê Judiciário, Revista USP, SP, EDUSP,

ARANTES, Rogério B. (1999) "Direito e política: o Ministério Público e a defesa dos direitos coletivos", Revista Brasileira de Ciências Sociais, 14:39, ANPOCS.

BECKER, Howard. (1977). Uma teoria da ação coletiva. RJ, Zahar.

BONELLI, M. Gloria (1995) “Os condicionantes da competição profissional no campo da justiça: a morfologia da Magistratura”, in Sadek, M. T. (org.). Uma introdução ao estudo da justiça, SP, IDESP/Sumaré.

(1998) “A competição profissional no mundo do Direito", in Tempo Social, 10:1.

- (1999). "O Instituto da Ordem dos Advogados Brasileiros e o Estado: a profissionalização no Brasil e os limites dos modelos centrados no mercado". Revista Brasileira de Ciências Sociais, 14:39.

BouRdIEU, Pierre. (1989). Poder simbólico. São Paulo, Difel.

(1997). Razões práticas. Campinas, Papirus.

CÂMARA DOS DePUTAdos (s.d.) - Deputados brasileiros, $6^{a}$ legislatura, 1967/1971, DF, Biblioteca da Câmara dos Deputados.

CARvalho, J. Murilo.(1980) - A construção da ordem: a elite política imperial, RJ, Editora Campus.

CORSI, Jerome R. (1984) Judicial politics: an introduction, N.J., PrenticeHall, Inc., 1984.
FALCÃO, Joaquim (1984) Os advogados: ensino jurídico e mercado de trabalho, Recife, Fundação Joaquim Nabuco / Editora Massangana, 1984.

FARIA, J. E. (org.) (1989). Direito e justiça: a função social do Judiciário, SP, Ática.

FOLHA de São Paulo (18/9/1994) “Olho no voto", Caderno Especial.

FLORY, Thomas. (1986). El juez de paz y el jurado en el Brasil imperial, 1808/1871, México, Fondo de Cultura Económica.

FREIDSON, Eliot. (1998). O Renascimento do profissionalismo. SP, EDUSP.

IDESP - Instituto de Estudos Econômicos, Sociais e Políticos de São Paulo. (1994). A crise do Judiciário vista pelos juízes. São Paulo. Relatório de Pesquisa.

. (1996). O Ministério Público e a justiça no Brasil. São Paulo. Relatório de pesquisa.

JACOB, Herbert et al. (1996). Courts, law and politics in comparative perspective. New Haven, Yale University Press.

JoHnSON, Terence J. (1972). Professions and power, Londres, Macmillan.

JUNQUEIRA, Eliane B. et al.. (1997). Juizes: retrato em preto e branco, RJ, Letra Capital.

KARPIK, Lucien (1990) "Technical and political knowlegde: the relationship of the lawyers and other legal professions to the market and the state", in Torstendahl, R. and Burrage, M., The formation of professions: knowledge, state and strategy, London, Sage Publications.

LARSON, Magali S. (1977). The rise of professionalism: a sociological analysis. Berkeley, University of California Press.

LEEUWEN, L. E. De Groot-Van (1992). “The equilibrium elite: composition and position of the Dutch Judiciary", in International Review of Sociology, 1992

LEMPERT, R. e SANDERS, .J. (1986). An invitation to Law and Social Science: desert, disputes and distribution, NY, Longman.

LIPSET, S. M. e BENDIX, R. (1963). Movilidad social en la sociedad industrial, Buenos Aires, EUDEBA. 
MARTIN, Elaine. (1990). "Men and women on the bench: vive la difference?", in Judicature, 73: 4.

MingARDI, Guaracy (1992). Tiras, gansos e trutas: cotidiano e reforma na Polícia Civil, SP, Scritta, 1992.

NALINI, J. R. (org.) (1992). Curso de Deontologia da Magistratura, SP, Saraiva.

Nelson, R., TrubeK, D. e Solomon, R. (eds.) 1992. Lawyers' ideals/ lawyers' practices: transformations in the American legal profession, Ithaca, Cornell University Press, 1992.

RoDRIGUES, Maria de Lurdes (1997). Sociologia das profissões, Oeiras/ Portugal, Celta.

RUESCHEMEYER, Dietrich (1986). "Comparing legal professions crossnationally: from a professions centered to a state-centered approach", in American Bar Foundation Research Journal, 3.

SADEK, M. Tereza (org.) (1995a) O Judiciário em debate, SP, IDESP/ Sumaré. (1995b) Uma introdução ao estudo da justiça. SP, IDESP/Sumaré.

SCHWARTZ, Stuart B. (1979) Burocracia e sociedade no Brasil colonial. SP, Perspectiva.

VIANNA, Luiz W. et al. (1997). Corpo e alma da magistratura brasileira. Rio de Janeiro, Revan/IUPERJ.

\section{O DILEMA DA DUPLA INSTITUCIONALIZAÇÃO DO PODER JUDICIÁRIO: \\ O CASO DO JUIZADO ESPECIAL DE PEQUENAS CAUSAS*}

André Luiz Faisting

\section{Introdução}

As transformações sociais em curso neste final de século, que influenciam as várias esferas da vida social e apontam para novas concepções de mundo, também impõem a necessidade de compreender o processo de reorganização das relações sociais. A esfera das relações jurídicas é uma das que mais sofre as consequências deste processo, uma vez que são as mudanças na forma de sociabilidade e de conflitualidade que caracterizam os novos conflitos de interesse, assim como a busca de mecanismos de resolução dos mesmos.

Pela sua própria natureza, são estes os conflitos que ameaçam a vida social. Assim, cabe à ordem jurídica encontrar a solução para estes litígios. Mas o que os analistas do Judiciário argumentam é que este Poder não tem a estrutura necessária nem está preparado culturalmente para solucionar os novos conflitos gerados pela sociedade contemporânea. Principalmente nas grandes cidades, marcadas pela ausência de diálogo e pela formalidade excessiva, a função do direito na solução destes conflitos não tem sido eficiente, pois os tribunais não conseguem atender a demanda que cresce em intensidade e complexidade. A consequência disto é a insatisfação, a desconfiança e o descrédito no Poder Judiciário.

Ao mesmo tempo, entretanto, vive-se hoje o fenômeno caracterizado pelo que se convencionou chamar de explosão da litigiosidade, entendida como um processo que decorre da maior conscientização dos cidadãos sobre os seus direitos, bem como sobre o que fazer para defendê-los. Isto também tem levado os agentes e estudiosos do sistema judiciário de muitos

* Artigo baseado na dissertação de mestrado, sob mesmo título, apresentada ao Programa de Pós-Graduação em Ciências Sociais da Universidade Federal de São Carlos, financiada pela FAPESP. Uma versão resumida desta pesquisa foi publicada na Revista Teoria e Pesquisa ${ }^{\circ}$ 28-29, do Departamento de Ciências Sociais da UFSCar. 
países a pensar em alternativas para atender às pessoas que buscam neste sistema a solução para seus problemas.

No Brasil, a busca de uma justiça mais informal levou à criação dos Juizados Especiais de Pequenas Causas, os quais se utilizam do instituto da conciliação prévia como forma de evitar a instauração do processo. Isto retoma a figura do conciliador, já praticada no âmbito da justiça do trabalho, para as chamadas pequenas causas, com litígios considerados até o limite de quarenta salários mínimos.

Tal fenômeno altera a composição do campo jurídico ${ }^{1}$, introduzindo novas disputas profissionais por áreas de atuação e monopólios de poder. Por isso, é preciso olhar a interação e a competição entre os diversos profissionais que lidam com a temática da conciliação prévia, para compreender as estratégias utilizadas na busca de seus fins, uma vez que a interação competitiva é dada pela posição que os diferentes profissionais ocupam neste campo ${ }^{2}$. Como este tipo de competição ganha maior transparência quando enfocada por meio das inovações recentes implementadas no Judiciário, os Juizados se constituem num espaço propício para este tipo de interação caracterizada pelos conflitos de competência profissional.

A grande maioria das publicações sobre os Juizados no Brasil tem como autores profissionais da área do Direito, alguns inclusive com experiência prática na função de conciliadores. Estes trabalhos têm em comum, além da valorização do Juizado como elemento decisivo no processo de mudança de mentalidade e postura profissional, a visão de que ele foi criado apenas como mais um instrumento do Judiciário na busca da

\footnotetext{
${ }^{1}$ Bourdieu define a teoria dos campos como um espaço social de relações objetivas, com autonomia relativa. Ele diferencia o conceito de "campo jurídico" do conceito de "corpo judiciário". No conceito de "campo" enfatiza as lutas para conservação ou transformação de suas relações de força. No conceito de "corpo social" destaca a coesão construída através do trabalho de instituição "que visa instituir de maneira duradoura em cada um dos membros da unidade instituída, sentimentos adequados a assegurar a integração, que é a condição de existência e de persistência desta unidade". Bourdieu, P. (1997) "Espíritos de Estado", Génese e Estrutura do Corpo Burocrático, Papirus e (1989) "A gênese dos conceitos de habitus e de campo", O Poder Simbólico, Difel.

${ }^{2}$ Ver Bonelli, M.G. "As interações dos profissionais do Direito em uma comarca do Estado de São Paulo", nesta publicação.
}

ampliação das vias de acesso por meio da informalização dos procedimentos.

Diferentemente desta visão, este artigo parte do pressuposto de que com a instalação dos Juizados no Brasil, criou-se também um processo de dupla institucionalização ${ }^{3}$ do Poder Judiciário, no sentido de que há duas formas distintas de prática judiciária, baseadas em lógicas também distintas: uma que visa o acordo entre as partes por meio da conciliação, conduzida por um advogado que desempenha a função de conciliador, e outra que busca a aplicação da justiça por meio do poder de decisão do juiz. Estas duas lógicas representam, portanto, uma tensão entre as duas pautas distintas da justiça contemporânea: a justiça formal de decisão e a justiça informal de mediação.

Foi com o intuito de compreender este tipo de tensão, bem como os dilemas e impasses decorrentes deste processo para a prática judiciária e para a interação profissional em torno desta nova instância de justiça, que se elegeu o Juizado Especial de Pequenas Causas em São Carlos como estudo de caso.

O problema colocado para a investigação - que se constituiu na principal hipótese que orientou a pesquisa - foi a de que este processo de dupla institucionalização cria também um dilema para juízes e conciliadores na escolha da prática judiciária, uma vez que ambos são formados e socializados dentro de uma lógica formal que valoriza o poder de decisão do juiz. Com isso, colocam o risco da reprodução na justiça informal dos procedimentos que são típicos da justiça formal.

Apesar deste quadro, os magistrados procuram manter o controle das duas justiças, impedindo, com isso, que uma nova classe de juízes leigos ou conciliadores tenha mais autonomia profissional, ao mesmo tempo em que os advogados-conciliadores buscam na construção de uma nova identidade profissional - baseada nos valores da conciliação - os argumentos para justificar a sua profissionalização como tal.

Neste sentido, as perguntas formuladas foram as seguintes: quais seriam as vantagens de um sistema que opera com base em duas lógicas

${ }^{3} \mathrm{O}$ conceito de dupla institucionalização foi extraído do texto de Lempert, R. e Sanders, J. "Creating New Systems: The Limits of Double Institutionalization" in An Invitation to Law and Social Science, Desert, Disputes and Distribution, NY, Longman, 1986. 
distintas, mas que conta com um mesmo profissional treinado e socializado na lógica da justiça formal de decisão? Seria mais adequada a criação de um sistema informal, separado da justiça formal, com a mediação sendo exercida por outro juiz, com outra carreira, com outro tipo de seleção?

Diante destas questões, este artigo se concentra, além da caracterização da demanda de processos e da questão da representação de advogados nas sessões de conciliação, no dilema dos magistrados na escolha da prática judiciária e na tentativa de profissionalização dos conciliadores a partir da interação com os outros profissionais. Ou seja, busca-se, essencialmente, compreender as estratégias que estes diferentes agentes de justiça acionam na busca de seus fins, no sentido de manter o controle das duas justiças, no caso dos magistrados, ou de se firmarem como profissionais qualificados para atuar apenas na justiça informal, no caso dos conciliadores.

\section{Os Juizados Especiais de Pequenas Causas: origens e dilemas}

Os Juizados Especiais de Pequenas Causas, órgãos da justiça estadual, foram criados no Brasil pela lei 7.244 de 07 de novembro de 1984, para atuar em causas cíveis com valor de até 20 salários mínimos, devendo orientar-se por critérios de simplicidade, rapidez, informalidade e economia processual. A lei não estipulava a obrigatoriedade de sua criação, mas estabelecia os critérios por meio dos quais deveriam atuar.

O cidadão que a eles recorre pode apresentar queixa de forma oral ou escrita, identificando a parte da qual reclama. O passo seguinte é a convocação de uma primeira reunião de conciliação com a presença de ambas as partes e de um conciliador. Se não houver acordo, o processo passa para a etapa seguinte, a de instrução e julgamento, assistida por um juiz. Em ambas as fases, além do acordo, outras soluções podem ser dadas pelo juiz, tais como a sentença ou, quando se tratar de assunto que extrapole a competência do Juizado, a extinção do processo. É garantido ainda o direito de recorrer da sentença dada pelo juiz na segunda fase do processo, cujo recurso será julgado por um conselho de juízes da Comarca, com exceção daquele que julgou em primeira instância.

O modelo inspirador do Juizado no Brasil surgiu na cidade de Nova Iorque, na qual se fez um esforço internacionalmente reconhecido no sentido de atender as pequenas causas que se acumularam durante décadas ${ }^{4}$. O Poor Man's Court, como os Juizados ali foram denominados, foi criado em 1934 com a finalidade de julgar causas de reduzido valor econômico, inferior a 50 dólares. Com a ampliação do conceito de pequenas causas, o tribunal passou a ser designado Common Man's Court ${ }^{5}$.

No Brasil, a criação dos Juizados começou a ser seriamente considerada a partir dos anos 80 , quando se discutiram medidas para amenizar a chamada crise do Judiciário ${ }^{6}$. A iniciativa veio, não do Judiciário, mas sim do Ministério da Desburocratização. A primeira experiência aconteceu em 1983 no Rio Grande do Sul, onde se testou um Conselho Informal de Conciliação ${ }^{7}$, cujo sucesso apressou a feitura da lei.

A desassistência jurídica, o congestionamento burocrático do Judiciário, bem como a morosidade nas ações eram constatações penosas. Ficava claro também que a crise não seria sanada somente a partir do reaparelhamento humano e material da Justiça, mas que novos mecanismos precisavam ser criados para que ações de pequeno valor não precisassem seguir todo o percurso de causas de maior valor e complexidade.

Os críticos da lei, que comparavam o Juizado ao INPS ${ }^{8}$, acreditavam tratar-se de uma justiça de segunda classe, pois entendiam que os conflitos economicamente menos expressivos teriam tratamento prejudicado na medida em que a essas pequenas causas fossem atribuídas a denominação de justiça dos pobres9. Para Dinamarco ${ }^{10}$, entretanto, a intenção era

${ }^{4}$ Carneiro, J.G.P. "Análise da estrutura e do funcionamento do Juizado de Pequenas Causas da cidade de Nova Iorque", (1985) in Kazuo Watanabe \& outros. Juizado Especial de Pequenas Causas, São Paulo, Revista dos Tribunais.

${ }^{5}$ Moraes, S.C. Juizado Especial Cível, Ed. Forense, 1998, p. 59.

${ }^{6}$ D' Araujo, Maria Celina. (1996) "Juizados Especiais de Pequenas Causas: um estudo de caso sobre a democratização da Justiça". Trabalho apresentado no XX Encontro Anual da ANPOCS, Caxambu - MG.

${ }^{7}$ Reis, A. O Processo das Pequenas Causas: História da Primeira Experiência. AJURIS, 9, 26, 1982.

Lacerda, G. Os Juizados de Pequenas Causas no Rio Grande do Sul. AJURIS, 10, 27, 1983. 8 “Juizado Especial de Pequenas Causas. Um INPS da Justiça?", Revista OAB, SP, 1984, pp. 28-29.

${ }^{9}$ Carneiro, J.G.P. “A Justiça dos Pobres”, AJURIS, 9 (25), 1982, p.73.

${ }^{10}$ Dinamarco, C.R. O Processo no Juizado de Pequenas Causas, Juizado Especial de Pequenas Causas, SP, Ed. RT, 1985, pp. 119-146. 
justamente o contrário, ou seja, uma justiça acessível, ágil, sem burocracia, e capaz de julgar conflitos referentes à modernização da sociedade.

Os Juizados também eram vistos pelos formuladores da lei como um instrumento de racionalização da prestação jurisdicional, pois, para eles, reunir numa única vara causas complexas e causas simples significava tornar inviável o caminho judiciário para a causa simples, e prejudicar bastante o andamento das causas complexas. Não se tratava, pois, segundo os defensores da lei, de ter duas justiças: uma melhor para os ricos, outra pior para os pobres. Tratava-se, exclusivamente, de racionalizar a prestação jurisdicional distinguindo causas cíveis complexas e causas cíveis simples.

Herkenhoff $^{11}$ observou que a Constituição fala em causas cíveis de menor complexidade e não em causas de menor valor econômico. Assim, a designação Juizados de Pequenas Causas não foi exata em face do texto constitucional. O melhor seria Juizado de Causas Cíveis de Menor Complexidade e Juizado Criminal de Infrações de Menor Potencial Ofensivo. Isto porque causas menos complexas são diferentes de causas de pequeno valor econômico. A correção desta designação veio com a lei n. ${ }^{\circ}$ 9.099, de setembro de 1995, que manteve os fundamentos da lei anterior, mas apresentou quatro importantes novidades. A primeira é que o valor das causas foi aumentado para 40 salários mínimos; a segunda é a obrigatoriedade da presença de advogado nas causas entre 20 e 40 salários; a terceira é que o Juizado passou a atuar também em pequenas causas na área criminal. Finalmente, tornou compulsória a sua organização nos estados.

As alterações da nova lei provocaram polêmicas entre juristas e na imprensa. Além de problemas de ordem legal na área criminal, vários especialistas argumentam que esta lei provocou um congestionamento nos Juizados, ou seja, acreditam que o acúmulo de processos é o resultado de uma boa intenção desarticulada da realidade. Além disso, a nova lei deixou ao Poder Judiciário de cada estado a incumbência de instalar quantos Juizados julgasse necessário. Segundo estes especialistas, o problema é que a lei não foi acompanhada de providências para aumentar e melhorar a

${ }^{11}$ Herkenhoff, J.B. Juizados para Causas Simples e Infrações Penais Menos Ofensivas (1994) Revista dos Tribunais volume 708, pp. 30-31. estrutura dos Juizados, capacitando-os para o desempenho das suas novas atribuições.

Os Juizados Especiais de Pequenas Causas foram precedidos pelos Juizados Informais de Conciliação em várias cidades do estado de São Paulo, inclusive em São Carlos, onde se desenvolveu a pesquisa. O êxito desta instituição, segundo Moraes ${ }^{12}$, pode ser comprovado pelo número de Juizados criados e instalados. O Brasil conta hoje com 759 Juizados, onde atuam 1170 juízes.

De fato, estes números revelam o êxito no que se refere à ampliação das vias de acesso à justiça. Por outro lado, identificam-se problemas de outra natureza como, por exemplo, a dinâmica profissional em torno do Juizado, bem como os conflitos decorrentes da representação de advogados nas sessões de conciliação, o que vai se refletir diretamente no tipo de tratamento oferecido aos usuários deste sistema.

A lei 9.099/95 prevê para os Juizados a existência de conciliadores e juízes leigos, mas, o mais comum, é a utilização de conciliadores ${ }^{13}$. Segundo o art. 98 da Constituição de 1988 o juiz leigo teria como função contribuir para a agilização das causas no Judiciário. A preocupação, entretanto, reside na profissionalização destes agentes, a exemplo do que acontece na justiça do trabalho. Ou seja, se já existe movimento para a extinção dos juízes classistas (juízes leigos da justiça do trabalho) também não seria coerente, segundo vários autores, a sua adoção nos Juizados ${ }^{14}$.

Outro problema apontado é que uma das maiores dificuldades para o profissional que exerce a função de conciliador é a possibilidade deste profissional confundir o seu papel com o papel do juiz, e assim falhar no desempenho satisfatório de qualquer um dos dois. Como conciliador ele pode inconscientemente impor um acordo pela ameaça implícita de seu poder de decidir. Como juiz, ele pode deixar seu esforço de conciliação subverter seu mandato de aplicador da lei.

\footnotetext{
${ }^{12}$ Moraes, S.C. op.cit. p. 94.

13 Assim está descrito no art. $7^{\circ}$ da referida lei: "Os conciliadores e juízes leigos são auxiliares da justiça, recrutados, os primeiros, preferencialmente, entre os bacharéis em Direito, e os segundos, entre advogados com mais de cinco anos de experiência".

${ }^{14}$ Cardoso, A.R, Justiça Anternativa: Juiados Especiais, BH, Nova Alvorada Ed. Ltda., 1996, p. 28.
} 
Este problema, decorrente da socialização que estes profissionais sofrem na lógica da justiça formal de decisão, característica da formação tradicional em Direito, traz consigo o dilema da dupla institucionalização do Poder Judiciário, na medida em que se criam formas distintas de prática judiciária. Este é o argumento de Lempert e Sanders ${ }^{15}$, que acreditam que, com a instalação da justiça informal de mediação nos Estados Unidos, criaram-se duas instituições que se baseiam em lógicas diferentes, mas que contam com um mesmo profissional treinado em uma única lógica dominante no sistema da justiça formal de decisão. Ou seja, "por mais que os juízes procurem ser mediadores ou conciliadores, não conseguem, no decorrer dos casos, descartar o papel judicial e o poder coercivo inerente que os acompanha."

Assim, o problema da dupla institucionalização torna-se sociológico no sentido em que não é uma institucionalização completa, ou seja, seria preciso treinar pessoas numa determinada crença, numa determinada cultura para a autorreprodução da instituição. O que os autores argumentam é que no caso americano o treinamento é baseado na valorização social do poder de decidir, e a justiça informal não tem, assim, uma escola própria para desenvolver a cultura da mediação.

Neste sentido, a dupla institucionalização cria um dilema para os juízes que têm que conciliar o papel de julgar com o papel de mediar, sendo que este último pode enfraquecer as bases normativas do Direito, além de minar a confiança da sociedade na sua imparcialidade. Por outro lado, se priorizarem o papel de julgar, não vão obter sucesso em implementar a conciliação. Em síntese, os autores acreditam que os Juizados não podem ser transformados em esferas que trabalhem exclusivamente com o modelo da conciliação.

O caso brasileiro, e especialmente o da Comarca de São Carlos, é um exemplo muito concreto de como esta dualidade pode atuar como um complicador. Isto porque o profissional que trabalha numa lógica do tipo "eu sou o juiz e, portanto posso decidir quem está certo e quem está errado", também trabalha com a outra lógica do tipo "eu vou mediar um acordo entre as partes". Ao final, a cultura profissional e o treinamento que cada profissão realiza para sua autorreprodução, para a criação de seu meio,

\footnotetext{
${ }^{15}$ Lempert, R. e Sanders, J., 1986, op.cit, p. 276 - tradução livre.
}

de sua lógica, não vão se completar e a dupla institucionalização pode representar a dominação de uma lógica sobre a outra em vez da duplicação.

Além disso, outro fator importante a ser observado a intensificação da disputa profissional com a criação dos Juizados. Os advogados vivenciam conflitos com a magistratura e com os colegas conciliadores em torno da questão da participação nas audiências, argumentando que a sua presença garante proteção à parte desfavorecida, muitas vezes de origem social humilde. Em contrapartida, juízes e conciliadores acreditam que tal presença afeta a principal característica destes tribunais informais que é a de agilizar os processos.

Aparece, portanto, um dilema entre a obrigatoriedade e a não obrigatoriedade da presença de advogado nas audiências. De um lado, a proibição da atuação de advogado pode efetivamente, como temem alguns, impedir a assistência jurídica a pessoas pobres e despreparadas, podendo-se supor, porém, que o atendimento informalizado desiniba tais pessoas. De outro lado, a não obrigatoriedade, que permite a presença opcional, não resolve o dilema, na medida em que a parte que comparecer sem advogado fica em situação desvantajosa se o adversário se fizer acompanhar de um profissional.

Em síntese, pôde-se constatar, pela pesquisa, que a conciliação é útil para muitas demandas e partes, especialmente quando se considera a importância de restaurar relacionamentos prolongados, em vez de simplesmente julgar as partes vencedoras ou vencidas. Mas, como bem aponta Cappelletti ${ }^{16}$ se, por um lado, a conciliação se destina a reduzir o congestionamento da justiça comum, por outro, a prática de acordos em determinados casos pode evitar que se obtenha uma norma técnica, destinada a proteger toda uma classe de pessoas.

\section{Análise da experiência do Juizado Especial em São Carlos}

O Juizado Especial de Pequenas Causas em São Carlos funciona desde junho de 1993. Ele conta com os seis juízes da Comarca, sendo um deles responsável pela parte administrativa do cartório. Eles se revezam nos plantões das sessões de conciliação para homologação dos acordos, que acontecem diariamente a partir das 18 horas, e nas audiências de instrução e

${ }^{16}$ Cappelletti, M. \& Garth, op.cit., p. 87. 
julgamento, que ocorrem quando não há acordo na primeira fase. Além disso, há uma instância de recurso denominada Colégio Recursal, constituída pelos próprios juízes da Comarca, que se reúne às segundasfeiras, quando necessário.

O cartório possui um setor denominado setor de triagem, no qual alguns funcionários recebem no balcão as solicitações individuais e decidem ali a competência do Juizado para encaminhar ou não as causas. Alguns funcionários são bacharéis em Direito e exercem um importante papel, não só pelo fato de decidirem se a causa deve ou não ser apresentada no Juizado, mas também, e, sobretudo, por orientarem e esclarecerem as pessoas quanto à natureza do Juizado e aos procedimentos a serem adotados, o que na justiça comum seria tarefa para um advogado. Os próprios funcionários preenchem os requerimentos a partir do relato do requerente, com exceção dos casos que entram com representação de advogado.

\section{Caracterização da demanda de processos}

Com o objetivo de caracterizar os processos que entraram no Juizado no período de 1993 a 1995, foram coletadas as seguintes informações de natureza quantitativa: resultado final e natureza dos litígios; nível ocupacional das partes; e tempo de duração do processo. Apresentamos a seguir os dados relativos ao resultado final para as duas fases do processo:
Tabela 1

Distribuição dos processos, por ano, segundo resultado na sessão de conciliação (Em percentagem)

\begin{tabular}{lllll}
\hline \multicolumn{5}{c}{ Ano } \\
\hline Resultado & $\mathbf{1 9 9 3}$ & $\mathbf{1 9 9 4}$ & $\mathbf{1 9 9 5}$ & Total \\
\hline Com acordo & 33,6 & 33,9 & 39,5 & 36,6 \\
\hline Sem acordo & 32,0 & 32,2 & 21,8 & 26,6 \\
\hline $\begin{array}{l}\text { Extinto ou sem } \\
\text { registro }\end{array}$ & 25,0 & 23,2 & 28,5 & 26,3 \\
\hline $\begin{array}{l}\text { Sentença à } \\
\text { revelia }\end{array}$ & 8,2 & 9,2 & 6,2 & 7,6 \\
\hline $\begin{array}{l}\text { Audiência } \\
\text { Redesignada }\end{array}$ & 1,2 & 1,5 & 4,0 & 2,9 \\
\hline $\begin{array}{l}\text { Total } \\
\mathbf{1 0 0}\end{array}$ & $\mathbf{1 0 0}$ & $\mathbf{1 0 0}$ & $\mathbf{1 0 0}$ \\
\hline
\end{tabular}

A tabela I, sobre a evolução do número de processos distribuídos mostra um crescimento no número total de processos. Estes passaram de 316 em 1993, para 526 em 1994 e 921 em 1995. Esta evolução é vista de maneira positiva pelos profissionais que atuam no Juizado, pois significa que o mesmo está atendendo cada vez mais pessoas, cumprindo, assim, o objetivo de ampliar o acesso à Justiça. Por outro lado, os próprios profissionais argumentam que, sem as providências necessárias para ampliar também a capacidade do Juizado, o risco é criar o mesmo problema da justiça formal, ou seja, a demora na resolução dos litígios. Este risco aumentou ainda mais a partir da publicação da lei 9.099, de setembro de 1995, que revogou a legislação anterior e ampliou significativamente a competência dos Juizados. Nos anos posteriores a este levantamento a demanda continuou crescendo. 
Tabela 2

Distribuição dos processos, por ano, segundo resultado na audiência de Instrução de Julgamento (em percentagem)

\begin{tabular}{lcccc}
\hline \multirow{2}{*}{ Resultado } & \multicolumn{3}{c}{ Ano } & \\
\cline { 2 - 4 } Com acordo & $\mathbf{1 9 9 3}$ & $\mathbf{1 9 9 4}$ & $\mathbf{1 9 9 5}$ & Total \\
\hline Sem acordo & 37,8 & 34,9 & 37,0 & 36,3 \\
\hline Extinto ou sem registro & 39,2 & 47,3 & 35,0 & 40,4 \\
\hline Audiência Redesignada & 2,0 & 1,8 & 4,5 & 3,0 \\
\hline Sentença à revelia & 4,0 & 2,4 & 0,5 & 2,0 \\
\hline Total & $\mathbf{1 0 0}$ & $\mathbf{1 0 0}$ & $\mathbf{1 0 0}$ & $\mathbf{1 0 0}$ \\
\hline Fonte: Cartório do Juizado Especia) & $\mathbf{( 1 0 1 )}$ & $\mathbf{( 1 6 9 )}$ & $\mathbf{( 2 0 0 )}$ & $\mathbf{( 4 7 0 )}$ \\
\hline
\end{tabular}

Fonte: Cartório do Juizado Especial de Pequenas Causas de São Carlos

A comparação entre as tabelas 1 e 2 indica que o percentual de acordo nas duas fases do processo (conciliação e julgamento) são praticamente iguais, ou seja, 36,6\% de acordo na fase de conciliação e 36,3\% de acordo na fase de instrução e julgamento. $\mathrm{O}$ mesmo, entretanto, não acontece com os casos em que não se alcança acordo, uma vez que o percentual aumenta de $26,6 \%$ na fase de conciliação para 40,4\% na fase de instrução e julgamento.

Assim, pôde-se constatar que quanto mais se avança nas etapas do processo no Juizado menos acordo se tem. Ou seja, o acordo tem mais chance de ser obtido no início do processo. Isto porque as duas fases possuem finalidades distintas: na primeira sessão, conduzida pelo conciliador, o objetivo é a busca de um acordo entre as partes através da conciliação. $\mathrm{Na}$ segunda fase, embora o juiz ainda tente um acordo entre as partes, caso isto não ocorra ele se utiliza de seu poder de decisão para sentenciar o processo.

Por outro lado, esta mudança de cenário também leva a refletir um pouco mais sobre os resultados dos processos associados à figura do juiz ou conciliador, uma vez que os mesmos $36,3 \%$ dos casos sem acordo na primeira fase, conduzida pelos conciliadores, acabaram alcançando acordo na segunda fase, presidida pelo juiz. Ou seja, se por um lado o percentual de não acordo aumenta quando da atuação do juiz, por outro, o mesmo juiz consegue ter sucesso em acordos que não foram realizados na primeira sessão, coordenadas pelos conciliadores.
Considerando, então, as duas fases do processo, um total de $46,3 \%$ dos litígios do período em referência tiveram como resultado final o acordo entre as partes. Isso não significa, entretanto, que o caso ficou encerrado, pois muitos processos que alcançam acordo acabam retornando ao Juizado por falta de cumprimento. Esta é a principal reclamação por parte dos profissionais, principalmente os cartorários. Os demais resultados ficaram assim distribuídos: $31,2 \%$ dos processos ou foram extintos ou não chegaram à sessão de conciliação; 10,7\% dos processos não alcançaram acordo; 7,9\% dos processos foram sentenciados à revelia, ou seja, na ausência do réu; e $3,5 \%$ dos processos tiveram suas audiências redesignadas.

Tabela 3

Distribuição dos processos, por ano, segundo a natureza dos litígios ${ }^{17}$ (em percentagem)

\begin{tabular}{lcccc}
\hline & \multicolumn{3}{c}{ Ano } & \\
\cline { 2 - 4 } Natureza dos litígios & $\mathbf{1 9 9 3}$ & $\mathbf{1 9 9 4}$ & $\mathbf{1 9 9 5}$ & Total \\
\hline Condenação em dinheiro & 93,8 & 96,4 & 99,3 & 97,3 \\
\hline $\begin{array}{l}\text { Condenação à entrega de coisa } \\
\text { certa móvel }\end{array}$ & 3,6 & 2,7 & 0,6 & 1,8 \\
\hline $\begin{array}{l}\text { Condenação ao cumprimento da } \\
\text { obrigação de fazer }\end{array}$ & 2,6 & 0,9 & 0,1 & 0,9 \\
\hline Total & $\mathbf{1 0 0}$ & $\mathbf{1 0 0}$ & $\mathbf{1 0 0}$ & $\mathbf{1 0 0}$ \\
& $\mathbf{( 1 0 1 )}$ & $\mathbf{( 1 6 9 )}$ & $\mathbf{( 2 0 0 )}$ & $\mathbf{( 4 7 0 )}$ \\
\hline
\end{tabular}

Fonte: Cartório do Juizado Especial de Pequenas Causas de São Carlos

Pode-se constatar, com relação à natureza dos litígios, que a quase totalidade dos processos refere-se à condenação em dinheiro, representando 97,3\% do total de processos distribuídos no período em referência. Estes processos dizem respeito a acidentes de trânsito, prestação de serviços, problemas entre inquilinos e proprietários, cobranças, reclamações de mercadorias entregues com defeito ou fora do prazo. Este indicador revela

${ }^{17}$ As causas foram registradas no Juizado em São Carlos de acordo com o artigo $3^{\circ}$ da lei $7.244 / 84$, ou seja, (I) condenação em dinheiro; (II) condenação à entrega de coisa certa móvel ou ao cumprimento de obrigação de fazer, a cargo de fabricante ou fornecedor de bens e serviços para consumo; (III) desconstituição e a declaração de nulidade de contrato relativo a coisas móveis e semoventes. 
que as pessoas buscam o Juizado, majoritariamente, quando desejam ser ressarcidas de seu prejuízo em dinheiro. Problemas de outra natureza, que não envolvem recursos financeiros, são praticamente inexpressivos.

Tabela 4

Nível hierárquico das ocupações de autores e réus do Juizado Especial de Pequenas Causas em São Carlos no período de 1993 a $1995^{18}$ (em percentagem)

\begin{tabular}{lccc}
\hline Nível & Autores & Réus \\
\hline $\begin{array}{l}\text { Profissionais liberais, cargos de gerência ou direção, } \\
\text { proprietários de empresas de porte médio }\end{array}$ & 17,5 & 10,0 \\
\hline $\begin{array}{l}\text { Proprietários de pequenas empresas comerciais, industriais, } \\
\text { agropecuárias, etc. (comerciantes) }\end{array}$ & 25,0 & 17,5 \\
\hline $\begin{array}{l}\text { Ocupações não manuais de rotina, supervisão de trabalho } \\
\text { manual e ocupações assemelhadas }\end{array}$ & 25,0 & 12,5 \\
\hline Ocupações manuais, especializadas ou não & 25,0 & 30,0 \\
\hline Aposentados e donas de casa & 7,5 & 5,0 \\
\hline Sem resposta & - & 25,0 \\
\hline Total & $\mathbf{1 0 0 \%}$ & $\mathbf{1 0 0 \%}$ \\
\hline
\end{tabular}

Fonte: Cartório do Juizado Especial de Pequenas causas de São Carlos

Como pode ser observada na tabela 4 , a variável relativa ao nível ocupacional das partes, considerada entre aqueles que aceitaram o acordo, indica que $25 \%$ dos autores e $17,5 \%$ dos réus são comerciantes. Sem considerar a condição de réu ou de autor, pôde-se constatar também que em $40 \%$ dos casos pelo menos uma das partes se definiu como comerciante. Esta constatação, juntamente com o indicador de que $97,3 \%$ do total de processos são relativos à condenação em dinheiro, revela que a transação comercial tornou-se um grande motivo para litigação na justiça informal.

Também constatou-se que apenas $17,5 \%$ dos autores são profissionais liberais de nível superior ou empresários, e apenas $10 \%$ dos réus são empresários ou empresas de porte médio. Os demais autores $(57,5 \%)$ e réus

\footnotetext{
18 Baseado na classificação de Gouvea, A.J., Ensino Médio e Desenvolvimento, SP,
} Melhoramentos, 1960
$(47,5 \%)$ possuem ocupações de nível médio ou operacional, constituídos em sua maioria de ocupações manuais, além de donas de casa e aposentados. No geral, portanto, tanto autores como réus ou fazem parte do mesmo universo profissional ou não possuem grandes distâncias em termos de status ocupacional. Assim, estes dados revelam que o Juizado em São Carlos, pelo menos a princípio, atuou mais na solução de conflitos entre indivíduos oriundos dos mesmos segmentos sociais do que entre indivíduos socialmente desiguais.

\section{Tabela 5}

Intervalo de tempo entre a entrada do processo e a sessão de conciliação, para o período de 1993 e 1995 (em percentagem)

\begin{tabular}{cc}
\hline Número de dias & Número de Processos \\
\hline$<10$ dias & $25 \%$ \\
\hline 11 a 20 dias & $45 \%$ \\
\hline 21 a 30 dias & $15 \%$ \\
\hline 31 a 40 dias & $7,5 \%$ \\
\hline 41 a 50 dias & $5 \%$ \\
\hline 51 a 60 dias & $2,5 \%$ \\
\hline Total & $\mathbf{1 0 0 \%}$ \\
\hline
\end{tabular}

Fonte:Cartório do Juizado Especial de Pequenas Causas de São Carlos

Apesar da preocupação dos profissionais com relação ao aumento do número de processos, o que se pode constatar a partir dos dados da tabela 5 , para o período em referência, foi que o tempo de duração não se constituiu em problema para o Juizado. Ao contrário, os números revelaram a extrema rapidez com que as audiências de conciliação foram realizadas. Para os casos que alcançaram acordo na sessão de conciliação, a demora para a realização da mesma foi, em média, 19 (dezenove) dias, o que demonstra uma significativa vantagem em relação à justiça comum.

Assim, pode-se constatar também que o problema estava menos localizado no tempo de duração do processo e mais concentrado no tipo de solução que foi dado aos conflitos. Ou seja, quando as partes entravam em acordo, que é a base sobre a qual operam os Juizados, o litígio era resolvido em poucos dias. Mas quando não havia acordo e o caso era encaminhado para audiência de instrução e julgamento, o processo não apenas 
demandava mais tempo, mas também acabava sendo submetido a procedimentos formais e burocráticos iguais aos da justiça comum, contrariando os princípios da lei das pequenas causas que são a oralidade, a simplicidade, a informalidade e a economia processual.

Por este motivo, resolveu-se concentrar nas razões que levaram ao resultado final do processo, associando-as a variáveis de natureza qualitativa como, por exemplo, o conflito profissional decorrente da polêmica questão da representação de advogado nas sessões de conciliação.

\section{Contrastes entre a presença e ausência de advogados}

Considerando que a presença de advogados representando as partes é um dos fatores determinantes da ritualização, desenvolvimento e resultado das audiências de conciliação, são três as situações possíveis com relação a este problema: primeiro, ambas as partes sem representação; segundo, ambas as partes representadas; e terceiro, apenas uma das partes representadas.

As audiências nas quais não há representação de advogados são caracterizadas pela maior segurança e liberdade tanto das partes como, e principalmente, dos conciliadores. Nesta situação, estes profissionais exercem com maior facilidade uma certa "pressão simbólica" junto aos litigantes na tentativa do acordo. Assim, neste tipo de situação, o acordo está diretamente relacionado à capacidade do conciliador em convencer os litigantes a transigirem. A questão, portanto, parece ser de como profissionais preparados para atuarem na lógica formal de decisão acabam utilizando-a na justiça informal de mediação.

Outro problema é que, apesar do conciliador exercer um papel decisivo para a conciliação entre as partes, existe uma diferença entre eles no que se refere ao desempenho desta tarefa, o que remete ao problema da falta de uniformidade. A maioria deles reclama da inexistência de procedimentos para ajudá-los nesta função. Também registram a falta de treinamento, sobretudo para aqueles que estão iniciando. Assim, ao reclamarem da falta de uniformidade e de treinamento, e ao defenderam o papel do conciliador como uma função especifica e diferente dos outros advogados e dos juízes, eles também apontam para a necessidade de criação de uma nova identidade profissional.
As audiências nas quais ambas as partes contam com representação de advogado é caracterizada, primeiro, pela baixa participação do conciliador enquanto elemento estratégico para conciliação, e, segundo, pela competição profissional entre os advogados.

A presença do advogado nas sessões de conciliação divide, inclusive, os próprios conciliadores. $\mathrm{O}$ fato deles também serem advogados atividade que lhes garante retorno financeiro, já que como conciliadores não são remunerados - muitas vezes os impede de ter um discurso contra os seus colegas. Ainda assim, a maioria dos conciliadores se manifestou contrária à presença do advogado nesta fase do processo, argumentando que as partes não precisariam de representação na informalidade.

Esse problema também remete à questão da disputa profissional, que pode ser observada tanto entre os advogados que representam as partes como entre advogados e conciliadores. Neste último caso, os conciliadores acabam tendo dificuldades para exercer seu papel quando têm que convencer não apenas as partes, mas também seus advogados a aceitar o acordo, o que certamente não ocorre nas audiências de instrução e julgamento, presididas pelos juízes.

O cenário no qual apenas uma das partes está representada por advogado retrata o problema da desvantagem da parte desacompanhada, também associado à atuação do conciliador. É evidente que a parte que possui um profissional especializado como seu procurador tem condições potencialmente maiores de argumentar tecnicamente sobre seus direitos, enquanto a parte desacompanhada muitas vezes nem compreende o que está ocorrendo naquele momento.

Neste sentido, caberia ao conciliador fornecer o equilíbrio necessário para que não haja prejuízo à parte sem representação. $\mathrm{O}$ problema é que o conciliador, por definição, deve ser imparcial, apenas transcrevendo em termos jurídicos a defesa das partes a partir do que elas próprias declaram. Assim, resta a questão: até que ponto o conciliador pode atuar em defesa da parte que está sem representação de advogado.

Embora muitos conciliadores considerem que não exista a desvantagem, pois, apesar de serem imparciais, fornecem o equilíbrio necessário entre as partes, não foi isso que foi observado nas audiências acompanhadas. Ou seja, como o conciliador tem que ser imparcial, torna- 
se evidente a desvantagem da parte desacompanhada. Em contrapartida, esta desvantagem pode ser maior ou menor dependendo do maior ou menor sucesso do conciliador na tentativa do acordo.

\section{A dupla institucionalização e as práticas judiciárias dos Magistrados}

A maioria dos juízes da Comarca de São Carlos ${ }^{19}$ valoriza o Juizado e a lógica da conciliação, embora na prática sinta dificuldade em conciliar o papel de julgar com o papel de mediar. Ainda assim, eles buscam seguir controlando as duas justiças e impedir, com isso, que uma nova classe de juízes leigos ou conciliadores assuma o controle da justiça informal, impondo a estes o caráter subalterno de auxiliares da justiça. Desta forma, garantem o controle da justiça informal por meio da homologação dos acordos que são realizados pelos conciliadores nas sessões de conciliação.

Ao afirmarem que não acreditam no processo de dupla institucionalização do Judiciário com a regulamentação da justiça informal, estes magistrados confirmam a hipótese de que desejam continuar mantendo o controle das duas justiças. Nesta direção argumentou um deles:

Não (há o risco do juiz perder o controle da justiça informal) porque a própria lei admite que a sentença pode ser revista pelo juiz togado (...) Há um dispositivo que admite que ele (juiz leigo ou conciliador) sentencie, que ele decida a questão. Só que esta decisão é sujeita a eventual apreciação do juiz togado que pode homologar ou rever. Então sempre vai haver uma fiscalização.

No que diz respeito à socialização dos profissionais na lógica da justiça formal, enquanto um dos magistrados acredita que a conciliação é mais uma forma de atuação que requer talentos especiais, outro considera que este tipo de socialização não se constitui em problema para o magistrado, pois a conciliação é a lógica da justiça ideal. Outro, ainda, acredita que os magistrados sentem grandes dificuldades em atuar como conciliadores pelos seguintes motivos:

\footnotetext{
${ }^{19}$ Dos seis magistrados da Comarca, quatro são da área cível e dois da área criminal. Com
exceção de um juiz da área cível, todos os demais colaboraram com a pesquisa, sendo dois
por meio de respostas escritas a um questionário aplicado, e um por meio de entrevista
pessoal pautada pelas mesmas questões. Também foram entrevistados os dois juízes da área
criminal, mas seus depoimentos não foram registrados. Assim, a amostra se restringiu aos

${ }^{19}$ Dos seis magistrados da Comarca, quatro são da área cível e dois da área criminal. Com
exceção de um juiz da área cível, todos os demais colaboraram com a pesquisa, sendo dois
por meio de respostas escritas a um questionário aplicado, e um por meio de entrevista
pessoal pautada pelas mesmas questões. Também foram entrevistados os dois juízes da área
criminal, mas seus depoimentos não foram registrados. Assim, a amostra se restringiu aos

${ }^{19}$ Dos seis magistrados da Comarca, quatro são da área cível e dois da área criminal. Com
exceção de um juiz da área cível, todos os demais colaboraram com a pesquisa, sendo dois
por meio de respostas escritas a um questionário aplicado, e um por meio de entrevista
pessoal pautada pelas mesmas questões. Também foram entrevistados os dois juízes da área
criminal, mas seus depoimentos não foram registrados. Assim, a amostra se restringiu aos

${ }^{19}$ Dos seis magistrados da Comarca, quatro são da área cível e dois da área criminal. Com
exceção de um juiz da área cível, todos os demais colaboraram com a pesquisa, sendo dois
por meio de respostas escritas a um questionário aplicado, e um por meio de entrevista
pessoal pautada pelas mesmas questões. Também foram entrevistados os dois juízes da área
criminal, mas seus depoimentos não foram registrados. Assim, a amostra se restringiu aos

${ }^{19}$ Dos seis magistrados da Comarca, quatro são da área cível e dois da área criminal. Com
exceção de um juiz da área cível, todos os demais colaboraram com a pesquisa, sendo dois
por meio de respostas escritas a um questionário aplicado, e um por meio de entrevista
pessoal pautada pelas mesmas questões. Também foram entrevistados os dois juízes da área
criminal, mas seus depoimentos não foram registrados. Assim, a amostra se restringiu aos três juízes da área cível, os quais permitiram o registro das declarações.
}

O profissional do Direito tem esse apego à forma (...) Então muitos processos são sentenciados por vicio de forma na postulação e na defesa. Você não chega nem a analisar, extingue o processo sem julgamento de mérito. Não chega a analisar o direito que está sendo discutido (...) A forma prevalece sobre o conteúdo.

A observação das audiências na justiça comum, nas quais atuam os magistrados, também permitiu constatar as dificuldades que eles sentem em conciliar o papel de julgar com o papel de mediar, oscilando, assim, entre estas duas lógicas de justiça. Apesar do discurso em favor da postura conciliatória, os magistrados nunca deixam de exercer também o poder de decisão característico de sua função. Esta mistura de conciliação e decisão se traduz, na realidade, no dilema vivenciado por eles na escolha da prática judiciária.

Ao serem colocados diante de situações que envolvem relações sociais cada vez mais dinâmicas e complexas, os juízes apostam na conciliação como solução para muitas das demandas. Mas o fato é que eles não foram preparados para serem conciliadores, uma vez que são formados e socializados em uma cultura institucional baseada no poder de decidir. $\mathrm{O}$ risco, portanto, é o predomínio da lógica formal de decisão num ambiente no qual deveria vingar a lógica informal de mediação.

Diante deste quadro, os próprios juízes reconhecem que a importância do Juizado seria justamente oferecer a possibilidade deles atuarem de outra forma, menos formal, menos burocrática, mais ágil. Com a explosão da litigiosidade, não só aumentou o número de litigantes, mas também diversificaram-se os tipos de litígio. Como os magistrados não têm domínio de outras áreas do conhecimento, sentem dificuldades em julgar determinados processos. Daí a conciliação passar a ser uma boa alternativa.

O problema parece ser o fato de que, se eles continuarem sendo formais e priorizarem o poder de decisão em detrimento da conciliação, poderão ver seu controle da justiça informal ameaçado por outros profissionais empenhados na construção de uma nova identidade baseada nos valores da conciliação. Esse risco foi percebido por um magistrado aposentado que assim se manifestou:

Melhor seria, portanto, que, a exemplo do Juizado Criminal, as funções dos dois Juizados (Cíveis e Criminais) fossem exercidas pelos próprios juízes de primeiro grau, já que a presença de juízes 
"leigos" ou "conciliadores" é não só dispensável, como não recomendável, em face justamente do movimento, inclusive de juízes togados, contra os "juízes classistas" na esfera trabalhista. Parecenos, pois, que não se devia criar outra classe de juízes leigos na justiça comum ${ }^{20}$.

\section{As estratégias de profissionalização dos conciliadores}

Dentro da ótica profissional, e de acordo com a concepção de "campo" em Bourdieu, os Juizados podem ser considerados como um espaço propício para a interação competitiva entre os diferentes agentes que lidam com a temática da conciliação. No que se refere especificamente aos advogados que desempenham a função de conciliadores, a questão principal é saber quais estratégias eles utilizam na busca da transformação deste "campo" - caracterizado pelas disputas profissionais - em um "corpo" coeso no qual se instituem sentimentos e valores como forma de assegurar sua integridade.

Ou seja, assim como os juízes divergem sobre várias questões, mas se unem quando o objetivo é defender os interesses da corporação, também os advogados conciliadores partilham de ideias comuns ao caracterizarem o seu perfil e ao valorizarem e defenderem a sua função como tal. No caso do Juizado em São Carlos $^{21}$, esta valorização está associada, principalmente, à tentativa de construção de uma nova identidade profissional que se baseia nos valores da justiça informal de conciliação.

Esta tentativa se sustenta, além da percepção dos objetivos do Juizado e da visão sobre os litigantes, na percepção e caracterização dos outros profissionais. Para se constituírem como profissionais capacitados para atuar na justiça informal, os conciliadores se baseiam, sobretudo, num processo de diferenciação em relação aos outros profissionais,

${ }^{20}$ Nogueira, Paulo Lúcio. Juizados Especiais Cíveis e Criminais, Editora Saraiva, 1996, prefácio, pág. XI

${ }^{21}$ O número de conciliadores em São Carlos é variável. No início do trabalho de entrevista havia aproximadamente vinte conciliadores. Conseguiu-se contato com quinze, doze dos quais aceitaram colaborar, mas apenas oito concordaram em gravar entrevista. Embora todas as entrevistas tenham sido consideradas na análise dos resultados, a amostra final se constituiu das oito entrevistas gravadas. principalmente os advogados que não são conciliadores, a quem atribuem o estereótipo negativo de formais e burocráticos.

Ao mesmo tempo, no entanto, eles buscam alianças com um segmento dos juízes e dos cartorários, no intuito de alcançarem legitimidade necessária ao exercício de sua função. Isto mostra que a construção desta identidade não é monolítica, mas sim múltipla e contraditória.

\section{A representação sobre o juizado e sobre os litigantes}

Enquanto um segmento dos conciliadores defende que a ampliação das vias de acesso pela gratuidade é a principal vantagem em relação à justiça comum, uma vez que a justiça informal atinge principalmente os mais carentes, outro segmento acredita que o Juizado foi criado simplesmente para trazer resultado e agilidade aos processos por meio da informalização dos procedimentos.

Resultado e agilidade, acesso amplo ou restrito, o importante é que todos eles concordam que o Juizado foi criado para dar solução a problemas que a justiça comum não consegue resolver. Por outro lado, eles não deixam de manifestar também a preocupação com o risco da reprodução dos procedimentos típicos da justiça comum, responsabilizando não apenas o Estado pela falta de estrutura, mas também a postura de juízes e advogados formais. Assim, utilizam-se deste estereótipo negativo para se diferenciar destes profissionais, unificando seus argumentos em torno da defesa do papel do conciliador e da constituição de uma nova identidade profissional.

Entre os conciliadores que veem na ampliação do acesso pela gratuidade o principal objetivo do Juizado, há que se destacar a concepção que defende a limitação deste acesso, restringindo a distribuição deste tipo de justiça àqueles que não podem arcar com as despesas de um processo na justiça comum. Este tipo de conduta transforma o problema do acesso em problema de restrição ao ganho do advogado. Assim argumenta um dos adeptos desta concepção:

Nós temos alguns usuários do Juizado que não deveriam usar, que são aquelas pessoas que têm condições de pagar um advogado e resolver através da justiça na sua tramitação normal, comum, e não 
no Juizado. Então como nós não temos essa verificação especifica eu acho que existem pessoas que estão utilizando e que não deveriam, tirando o lugar de outros.

Neste sentido, ao restringir o acesso ao Juizado às pessoas carentes, este tipo de concepção voltada afazer o bem objetiva, na realidade, não apenas caracterizar o conciliador como um profissional disposto a ajudar os mais desprovidos de justiça, mas também busca garantir o seu ganho como advogado na justiça comum.

Com relação à representação do perfil dos litigantes, enquanto um segmento dos conciliadores caracteriza os usuários como maus demandantes, que utilizam o Juizado para resolver questões pessoais que não têm tradução jurídica, outro segmento caracteriza as partes como pessoas simples e humildes, que finalmente estão tendo a chance de resolver seus problemas pela via judicial.

O mais importante, no entanto, é que ambas as visões colocam para o conciliador o desafio de se constituir como um profissional qualificado para atuar na solução deste tipo de demanda característica do Juizado. Ou seja, mesmo considerando a diferença na caracterização do perfil dos litigantes, a questão é que os dois segmentos dos conciliadores se utilizam destas representações para também construírem a sua autoimagem e, assim, defenderem e valorizarem a sua função.

Em outras palavras, a postura que imputa às partes a responsabilidade pelo mau funcionamento do Juizado, valoriza a função do conciliador ao mostrar ser necessário possuir determinadas características para bem exercer esse papel, o que não é comum na maioria dos advogados. O outro segmento, ao caracterizar os litigantes como pessoas simples e humildes que apenas buscam ter seus direitos garantidos, da mesma forma que o primeiro segmento, utiliza-se da caracterização dos litigantes para também construir sua autoimagem, indicando, assim, o perfil ideal do conciliador.

\section{Os outros profissionais}

A postura diante do problema da representação de advogados nas sessões de conciliação é uma das principais divergências entre os conciliadores. Enquanto alguns deles não se sentem seguros em posicionarse contrários a tal presença - mesmo sendo visível a dificuldade que sentem para alcançar o acordo quando o advogado se faz presente - a maioria, no intuito de preservar sua imagem diante da ameaça que o advogado traz ao exercício de sua função, posiciona-se totalmente contrária à presença do advogado. Este último segmento, portanto, possui uma identidade mais clara com a função do conciliador.

Entre aqueles que defendem que a presença do advogado não atrapalha a tentativa de conciliação, pode-se constatar também um maior condicionamento pela lógica da justiça formal de decisão. Este condicionamento se dá pela maior ou menor socialização que eles sofrem nesta lógica formal, e tem como principais fatores, além da formação acadêmica tradicional em Direito, a origem familiar e o tempo de experiência profissional.

Segundo os próprios conciliadores, os futuros bacharéis não são treinados pelas Faculdades de Direito para atuarem na lógica da justiça informal de mediação. Como a formação acadêmica é comum a todos os conciliadores, a origem familiar e o tempo de experiência profissional passam a ser fatores decisivos no grau de socialização dos mesmos. Por exemplo, o segundo conciliador com mais tempo de exercício profissional na justiça formal - 13 anos - assim se manifestou com relação ao problema da representação:

(a presença do advogado) ajuda e muito. Ajuda porque o advogado tem uma visão já do que poderá acontecer com aquele direito da parte. Então a composição sempre atende a ambas as partes. Então a parte acompanhada do advogado facilita muito o acordo (...) Também (o trabalho do conciliador é facilitado) porque já é uma coisa mais direta com os advogados (...) então facilita muito. Não é que não seja possível realizar o acordo entre as partes diretamente sem o advogado. Como o advogado conhece a técnica do processo e a parte não, o que poderá acontecer é ele (o advogado) ter uma visão mais adiante do que poderá causar prejuízo a uma parte ou a outra.

Como se vê, este conciliador evita criticar e se diferenciar dos colegas advogados por também se considerar um deles. Assim, apesar da autovalorização como conciliador, ele ainda é condicionado pela função de advogado que atua na justiça formal. 
Outro indicador deste tipo de condicionamento é que uma representante deste mesmo segmento é a única entre os entrevistados que tem origem em uma família na qual há outros profissionais com socialização no mundo do Direito. Diferentemente da maioria de seus colegas, ela não acredita que o advogado atrapalhe. Ao contrário, defende que este profissional tem uma função importante e necessária na justiça, pois é ele quem representa os interesses de seu cliente.

(o advogado) não atrapalha. A postura que ele toma às vezes pode atrapalhar, mas quem tem aí que tomar a frente da coisa é o conciliador (...) A postura do conciliador ai é que vai dizer o andamento de uma audiência.(...) Então eu não acredito que o advogado atrapalhe. Eu acho que ele é uma função necessária da justiça (...) Então, na verdade, não é o advogado funcionando dentro da justiça, do Juizado de Pequenas Causas. É a postura que ele toma. É a postura que o conciliador tem que tomar. Então veja bem: se o advogado está enrolando, alguém tem que fazer ele parar. Agora, o interesse do cidadão tem que ser defendido. E quem sabe fazer isso é o advogado.

O mais interessante neste tipo de postura, no entanto, é que ao mesmo tempo em que defende a necessidade da presença do advogado, também valoriza a função do conciliador, trazendo para este a responsabilidade de não deixar que o advogado atrapalhe a tentativa de conciliação.

Neste tipo de visão, percebe-se que o entrevistado oscila entre a função de conciliador e a de advogado. Como advogado, não pode trair a classe à qual pertence, desconsiderando a importância da atuação deste profissional em qualquer instância da justiça. Por outro lado, como conciliador, é preciso diferenciar-se daqueles advogados formais e sem espírito conciliatório. Neste sentido, esta posição também evidencia com mais clareza o dilema da dupla institucionalização, no sentido em que há duas lógicas distintas de prática judiciária, mas um único profissional treinado e socializado na lógica da justiça formal de decisão.

O outro segmento dos conciliadores, que se posicionou de forma enfática contra a presença de advogados nas sessões de conciliação, construiu uma identidade mais clara com a função de conciliador. Este segmento argumenta que, por ser o advogado essencialmente litigante, é técnico e não se envolve com as partes, diferentemente do conciliador: quando a conciliação é conduzida sem a presença de advogado ela acaba acontecendo com mais facilidade (...) E quando (as partes) se colocam frente a frente e alguém com uma habilidade, uma capacidade para conduzir a conversa, os ânimos acabam sendo moderados, as pessoas acabam reconhecendo que não é por aí, acabam até se dando as mãos nas audiências, se pedindo perdão. Mas quando o advogado está ali para defender ou para acusar (...) ele está recebendo para brigar pelo cliente. Então, a participação do advogado tem sim atrapalhado muito as conciliações.

O que se pode observar a partir deste tipo de percepção é que, ao mesmo tempo em que é ressaltada a grande dificuldade na tentativa de conciliação em função da presença do advogado, também caracteriza-se o conciliador como o verdadeiro agente do processo de distribuição de justiça. A crítica feita ao advogado se traduz, na realidade, na demarcação da diferença entre as duas funções - a de conciliador e a de advogado. A ameaça causada pela postura do advogado faz com que ele seja caracterizado pelos conciliadores como um profissional típico da justiça formal, sem condições, portanto, de atuar na justiça informal.

Neste sentido, ao diferenciarem-se do advogado, caracterizando-o como técnico e sem espírito conciliatório, ao mesmo tempo em que valorizam sua função, os conciliadores adeptos deste tipo de visão também idealizam um perfil profissional que os qualifica a atuar na justiça informal de mediação, apontando, assim, para a necessidade uma nova identidade profissional baseada nos valores da conciliação.

No que diz respeito à visão dos conciliadores sobre os magistrados, a maioria deles demonstrou a adesão aos juízes da Comarca. O reconhecimento de que os juízes estão sobrecarregados, bem como o fato de acreditarem que os magistrados devem estar preparados para atuar em beneficio das "grandes causas", também justifica, na realidade, a necessidade do trabalho dos conciliadores. Além disso, por estarem subordinados aos juízes, estrategicamente não seria adequado contrapor-se aos magistrados mais próximos, que detêm o poder de controlar suas ações:

Especialmente em nossa cidade, o juiz que cuidava do trâmite legal dos processos é um juiz que merece todo o respeito, toda a admiração pelos seus julgados, mas que acumulou função (...) Eu acho que os juízes não devem perder o tempo deles com causas pequenas, com 
coisas que poderiam ser resolvidas de outra maneira. Então eu acredito que foi por ai que se resolveu criar um mecanismo para desafogar a justiça. Eu acredito que os juízes devem se ater a grandes causas, a coisas mais complexas (...) Então, nada melhor que um conciliador para fazer isso. É melhor ter vários conciliadores. O juiz tem o seu tempo a peso de ouro.

Neste sentido, ao buscarem uma nova identidade profissional, os conciliadores diferenciam-se dos advogados ao mesmo tempo em que valorizam a função dos magistrados, buscando, com isso, aliança e cooperação com os mesmos no intuito de alcançarem o reconhecimento necessário à importância de sua função.

Da mesma forma, um segmento dos conciliadores também valoriza o trabalho dos funcionários do cartório. Um desses conciliadores, que inclusive já exerceu a função de cartorário antes da advocacia, além de ressaltar a importância destes funcionários para $\mathrm{o}$ funcionamento do Juizado, argumenta que se os mesmos trabalhassem com maior liberdade também seria possível evitar a formalização e a burocratização do cartório.

O cartório é excelente. O pessoal, em si, é excelente. Eles são atenciosos, são ótimos. Eu acho até que eles têm uma sobrecarga de responsabilidade muito grande. Agora o que eu acho é que o juiz que responde pelo Juizado deveria dar mais autonomia para o pessoal do cartório (...) Então eu acho que eles deveriam trabalhar com maior liberdade (...) Essa liberdade de atuação para o cartorário, ele vai ter iniciativa para resolver as coisas. Ele vai crescer com isso. Porque tudo aquilo que você mantém preso a uma linha de conduta que não permite uma livre iniciativa tolhe a pessoa. E quando você está tolhendo você trava tudo, você burocratiza (...) A informalidade e a desburocratização do sistema. Não adianta ter o princípio da informalidade e ser burocrático que vai travar da mesma forma. Uma coisa esbarra na outra. O cartório tem que ser informal.

Mas enquanto esse segmento considera que os funcionários do cartório exercem com empenho e competência o seu trabalho, há outro segmento que reforça as diferenças entre o conciliador e o cartorário no intuito de demarcar os espaços de atuação, limitando, assim, as atribuições dos funcionários. Desta forma, não permitem que os cartorários, assim como os advogados, ameacem a sua função.
Na parte legal eu não vejo que eles (os cartorários) tenham que influir. Eles não precisam entender (de direito). $\mathrm{O}$ que eles precisam é saber redigir e apresentar o problema (...) Eu acho que a parte legal quem tem que entender é o conciliador e o juiz (...) $\mathrm{O}$ escrevente não tem obrigação de entender a lei, a obrigação de dizer quem está certo e quem está errado. Ele tem a obrigação de colocar no papel da melhor maneira a história, contar a história, de narrar o que está acontecendo. E é lógico, ele tem que ter conhecimento dos documentos que a pessoa precisa para isso (...) Porque senão também você corre o risco de ter o escrevente dando palpite na audiência.

Como pôde ser observado, ao mesmo tempo em que um segmento dos conciliadores valoriza a importância dos funcionários do cartório, o outro não deixa de demarcar a diferença de funções entre o cartorário e o conciliador, assegurando, assim, a autonomia deste em relação ao primeiro. O mais importante, no entanto, é que tanto a falta de estrutura associada à sobrecarga de trabalho dos cartorários, quanto a limitação de suas funções, justificam a profissionalização do conciliador.

Assim, do ponto de vista da profissionalização, pode-se concluir que, assegurada a diferença de papéis, os conciliadores buscam alianças também com os cartorários através do reconhecimento de sua importância. Neste sentido, a tentativa de construção de uma nova identidade profissional por parte dos conciliadores passa, além do processo de diferenciação em relação aos demais advogados, pela necessidade de criar alianças com juízes e cartorários, seja pela importância funcional que estes dois segmentos profissionais possuem dentro do sistema do Juizado, seja pela garantia de apoio necessário à legitimação da função do conciliador.

\section{Uma nova carreira profissional?}

Entre os conciliadores entrevistados há um segmento que acredita que o Juizado, na realidade, está reproduzindo os mesmos procedimentos da justiça formal. Os responsáveis por esta reprodução seriam, segundo este grupo, justamente os profissionais que, por serem naturalmente litigantes, não foram preparados para atuar na lógica que seria própria da justiça informal de conciliação.

As pessoas procuram o Juizado e recebem a informação que é uma coisa muito fácil (...) Quando ele chega lá percebe que o 
procedimento é um procedimento comum (...) E essas formalidades o público não conhece (...) Nós (advogados) somos litigantes, naturalmente litigantes (...) Por que na conciliação a presença do advogado interfere? Claro. Ele não está preparado para isso. Nós não fomos formados para isso. E os conciliadores que pensam como eu, os juízes que pensam como eu estou pensando agora é porque eles tem uma sensibilidade muito grande, é porque eles não estão movidos só pela questão técnica (...) porque os juristas, o conciliadores que pensam como eu tem outras motivações também. Tem a motivação da justiça, tem a motivação do próximo, não é motivação só técnica não.

Os argumentos acima fortalecem a hipótese de que a formação e a socialização dos profissionais na lógica da justiça formal condiciona-os quando eles atuam na justiça informal. $\mathrm{O}$ que não constava da hipótese é que alguns conciliadores não apenas aceitam este fato, mas também utilizam-se dele para diferenciar-se dos demais advogados e de alguns juízes, apontando, assim, para a necessidade de uma nova identidade profissional que os qualifique para atuar na justiça informal.

Do ponto de vista da profissionalização dos conciliadores, portanto, o mais importante a ressaltar é que, ao mesmo tempo em que se critica os advogados e juízes técnicos e insensíveis, ressalta-se a diferença em relação a estes profissionais, argumentando que os conciliadores possuem outras motivações como a justiça e o bem estar do próximo. Ou seja, parte-se novamente do processo de diferenciação e do estereótipo negativo criado para caracterizar os outros profissionais - técnicos e formais - com o intuito de justificar a profissionalização.

Outro indicador do objetivo dos conciliadores em profissionalizar-se nesta função diz respeito à possibilidade de outros profissionais, que não sejam bacharéis em Direito, exercerem esta atividade. A maioria dos entrevistados posicionou-se de forma contrária a tal possibilidade, assegurando, com isso, o monopólio da função de conciliador apenas aos bacharéis em Direito.

Eu acho que o conciliador tem que ter preparo e conhecimento da lei. Porque senão ele vai prejudicar um em detrimento do favorecimento do outro. E ele também não tem nenhuma obrigação ética para com a justiça. Então, vem um amigo seu lá (...) e você vai acabar fazendo justiça com as próprias mãos e não calcadas no direito, na verdade e na justiça (...) Eu acho que o conciliador tem que ser uma pessoa que tenha feito uma Faculdade de Direito (...) Como um contador, que estuda números, pode ir lá e falar do que nós estudamos a vida inteira. Nós temos que estar atualizados sempre.

Ao pautarem suas falas pela defesa do monopólio da função do conciliador, entendido como um profissional diferente dos demais advogados e dos juízes, e ao colocarem a necessidade de treinamento, cursos, palestras, provas, concursos etc., os conciliadores também acabam apontando para a necessidade de construção de uma nova carreira profissional.

Se o Juizado pudesse trabalhar a figura do conciliador de uma outra forma. Até que se preparasse o conciliador em nível de concurso, que fossem minijuízes. Como por exemplo, na justiça do trabalho existem os juízes classistas. É uma pessoa qualquer, alguém que o sindicato indica, mas quando ele está sentado ali como juiz classista há o respeito por eles (...) O juiz classista tem para nós o mesmo poder, a mesma influência. Lá na conciliação (no Juizado) não. Tem até alguns advogados que dizem: - não vou perder meu tempo sendo conciliador. Vai lá quem não tem o que fazer (...) Se houvesse uma escola, um curso, ou o dia-a-dia mesmo que você vai progredindo naquela carreira, por número de pontos em conciliação, por uma atuação, tudo é um incentivo. Poderia até ser válido: uma carreira progressiva dentro da conciliação.

Em síntese, apesar de alguns conciliadores utilizarem-se da crítica e da diferenciação com os demais advogados, enquanto outros evitam criticar a classe a qual ainda pertencem, o fato é que todos estão empenhados na criação de uma nova identidade profissional, que se sustenta, por um lado, na tendência à informalização dos procedimentos e da postura profissional, e, por outro, no processo de dupla institucionalização do Poder Judiciário.

\section{Conclusões}

A caracterização da demanda de processos no Juizado em São Carlos mostrou que o número crescente de litígios no período investigado significou também uma ampliação do acesso a essa nova instância de justiça. Por outro lado, esta ampliação aponta para o risco de reproduzir o problema típico da justiça formal, qual seja, a lentidão na solução dos 
litígios. Embora para este período a demora não tenha se constituído em problema, revelando uma significativa vantagem em relação à justiça comum, o aumento do número de processos, aliado ao risco de formalização e burocratização do cartório, representam a maior preocupação por parte dos profissionais da justiça informal.

Os dados relativos à natureza das causas e à ocupação das partes revelaram que a transação comercial tornou-se um grande motivo para litigação também na justiça informal. Mas as pessoas que mais processaram e foram processadas no Juizado são oriundas de segmentos médios e operacionais, principalmente de ocupações manuais não especializadas, mostrando, assim, que o Juizado em São Carlos, não se constituiu num fórum exclusivo de solução de conflitos entre indivíduos de diferentes segmentos sociais.

Outro indicador quantitativo importante diz respeito ao resultado final dos processos nas duas fases. A primeira constatação foi que quanto mais se avança nas etapas do processo menos acordo se obtém. Por outro lado, também pode-se constatar que um terço dos processos em que não houve conciliação na primeira sessão alcançaram acordo na segunda fase. Assim, pode-se concluir que a mudança de cenário associada à figura do terceiro institucionalizado -juiz e/ou conciliador - influencia diretamente a expectativa e a decisão das partes, sendo o juiz mais valorizado e respeitado tanto pelos litigantes como pelos advogados representantes das partes.

Após a análise dos dados quantitativos constatou-se que o principal problema a ser investigado no Juizado em São Carlos não estava associado ao acesso em termos de aumento de demanda, mas sim ao tipo de tratamento que foi dado aos litígios e aos litigantes. Por isso, optou-se por concentrar, primeiro, na polêmica questão da presença de advogados representando as partes; segundo, no dilema dos magistrados na escolha da prática judiciária; e terceiro, nas estratégias de profissionalização dos conciliadores.

Com relação à presença de advogados nas sessões de conciliação, a principal constatação foi que quando não houve representação os conciliadores sentiram-se mais seguros de sua função, pois puderam conversar diretamente com os litigantes. Nesta situação, o conciliador exerceu com mais facilidade uma "pressão simbólica" sobre as partes, buscando impedi-las de continuarem com a demanda e induzindo-as ao acordo. Nestas circunstâncias, portanto, o sucesso do conciliador também foi maior.

Quando ambas as partes estavam representadas por advogados ocorreu o contrário. Esta situação, caracterizada pelo conflito de competência profissional, é ainda mais grave quando envolve o advogado e o conciliador, pois apesar dos conciliadores ocuparem uma posição estratégica no Juizado, eles são vistos como iguais pelos seus colegas advogados. Por serem os advogados essencialmente litigantes e buscarem garantir os interesses de seus clientes a qualquer custo, os conciliadores sentem dificuldades no exercício de sua função quando têm que convencer não apenas as partes, mas também seus procuradores a transigirem.

O cenário onde apenas uma parte estava representada por advogado revelou o problema da desvantagem para a parte desacompanhada. Apesar de alguns conciliadores não acreditarem que existe o prejuízo, argumentando que eles devem fornecer o equilíbrio necessário entre as partes, nossa pesquisa revelou o contrário. Ou seja, pelo fato do conciliador ter que se mostrar imparcial, a parte acompanhada de advogado tem mais condições de fazer sua defesa argumentando com o conciliador. Por outro lado, esta desvantagem pode ser maior ou menor dependendo do maior ou menor sucesso do conciliador na tentativa do acordo.

A partir da pergunta inicial colocada para investigação, no sentido de questionar como pode um sistema operar com base em duas lógicas distintas, contando com uni mesmo profissional treinado e socializado na lógica da justiça formal de decisão, buscou-se compreender quais as estratégias que os diferentes agentes de justiça utilizam-se na busca de seus fins, no sentido de continuar mantendo o controle das duas justiças, no caso dos magistrados, ou de se firmarem como profissionais qualificados para atuar na justiça informal de mediação, no caso dos advogadosconciliadores.

A conclusão final com relação aos objetivos dos conciliadores é que, apesar de algumas diferenças pontuais (por exemplo, na questão da representação de advogados), o que leva ao problema do condicionamento pela socialização na lógica da justiça formal, eles estão empenhados na construção de uma nova identidade. Esta nova identidade sustenta-se, por um lado, na valorização da função da maioria dos juízes e cartorários no intuito de construir alianças para a legitimação necessária ao exercício de 
sua função; e, por outro, no processo de diferenciação em relação aos demais advogados, a quem atribuem o estereótipo negativo de formais e sem espírito conciliatório. Para tanto, os novos conciliadores fundamentamse num discurso baseado na tendência à informalização da justiça como forma de justificar a sua profissionalização.

No que diz respeito aos juízes, a conclusão é que, apesar da tendência à dupla institucionalização, os magistrados procuram manter o controle das duas justiças, impedindo, com isto, que uma nova classe de juízes leigos ou conciliadores tenha maior poder e autonomia profissional. Ao mesmo tempo, entretanto, sofrem um dilema ao ter que conciliar o papel de julgar com o papel de mediar, oscilando, assim, entre estas duas práticas judiciais. Com isso, correm o risco de ver o controle da justiça informal ameaçado pelo segmento dos conciliadores, que estão claramente empenhados na construção de uma nova identidade profissional, baseada apenas nos valores da conciliação.

Neste sentido, as dificuldades encontradas pelos conciliadores ocorrem em dois níveis. Primeiro, a superação do condicionamento a que estão sujeitos na justiça comum, cenário onde também atuam e no qual garantem o seu ganho financeiro. Segundo, romper com a resistência da magistratura, que não aceita a duplificação do sistema e deseja continuar mantendo o controle da justiça informal. Assim, o principal risco para os objetivos dos conciliadores são justamente os interesses "conservadores" da magistratura.

\section{Bibliografia}

ARAúJO, M. C. (1996) Juizados Especiais de Pequenas Causas: um estudo de caso sobre a democratização da justiça, ANPOCS, Caxambu MG.

Bonelli, M. G. (1998) “A Competição Profissional no Mundo do Direito”, Tempo Social, 10, 1: 185-214.

Bourdieu, P. (1997) Gênese e Estrutura do Campo Burocrático, SP, Papirus.

Bourdieu, P. (1989) Poder Simbólico, São Paulo, Difel.

CAmpos, A. M. (1985) Juizado Especial de Pequenas Causas, SP, Saraiva.
CAPPelletti, M. e Garth, B. (1988) Acesso à Justiça, trad. Ellen Gracie Northfleet, Porto Alegre, Sérgio Antonio Fabris Editor.

CARdoso, A. P. (1996) A Justiça Alternativa: Juizados Especiais, B.H, Nova Alvorada Edições.

CARneiro, J. G. P. (1982) “A Justiça dos Pobres”, AJURIS, 9 (25).

. (1981) "Juizado de Pequenas Causas. Uma proposta de ampliação do acesso do Judiciário", Revista $O A B / R J, 17,93-102$.

. (1985) "Análise da estrutura e do funcionamento do Juizado de Pequenas Causas da cidade de Nova Iorque", Kazuo Watanabe (org.) Juizado Especial de Pequenas Causas, São Paulo, Revista dos Tribunais.

Ceneviva, W "Questões de Pequeno Valor Econômico", Folha de São Paulo, 26/09/82

Cimino, E. A. "Como obter desfecho mais rápido na ação", Estado de São Paulo, 31/12/79

Corte LeAl, L. A. (1982) “Os Juizados de Pequenas Causas”, AJURIS, 9 (26)

CunHA, J.S.F. (1997) Questões Controvertidas nos Juizados Especiais, Curitiba, Juruá Editora

. (1997) Recursos e Impugnações nos Juizados Especiais, Curitiba, Juruá Editora

DiNAMARCO, C.R. (1986)"A lei das pequenas causas e a disciplina da jurisdição", Manual das Pequenas Causas, SP, Revistas dos Tribunais

. (1985) “O Processo no Juizado de Pequenas Causas”, Juizado Especial de Pequenas Causas, Watanabe, K. (org.), Ed. Revista dos Tribunais.

Dorfmann, F.N. (1989) As Pequenas Causas no Judiciário, Porto Alegre, Sergio Fabris Editor

FARIA, J.E. (1994) “Os Desafios do Judiciário”, Revista USP, 21: 46-57.

FIGUEIRA JR., J.D. e LoPES, M.A.R. (1995) Comentário à Lei dos Juizados Especiais Cíveis e Criminais, Editora Revista dos Tribunais. 
FREIDSON, E. (1998) Renascimento do Profissionalismo, SP, EDUSP.

GRINOVER, A.P. (1985) "Aspectos constitucionais dos Juizados de Pequenas Causas", Watanabe, K. (org.), Juizado Especial de Pequenas Causas, S.P., Revista dos Tribunais.

HERKENHOFF, J.B. (1994) "Juizados para causas Simples e infrações penais menos ofensivas", Revista dos Tribunais, vol. 708.

Lacerda, G.(1983) "Os Juizados de Pequenas Causas no Rio Grande do Sul”, AJURIS, 10,27.

Lagastra Neto, C. (1983) “Anteprojeto do Juizado de Pequenas Causas". R.T. vol. 567.

LAGASTRA Neto, C. (1986) "Acesso à Justiça e Ampliação da Lei do Juizado Especial de Pequenas Causas", Revista dos Tribunais, vol.. 612.

LEMPERT, R. e SANDERS, J. (1986) An Invitation to Law and Social Science: Desert, Disputes and Distribution, NY, Longman.

LIMA LOPES, J.R. (1994) "Justiça e Poder Judiciário ou a Virtude Confronta a Instituição". Revista USP, 21: 22-33.

LOPES, M.A.R. (1995) Lei dos Juizados Especiais Cíveis e Criminais anotada Ed. R.T.

LuHMan, N. (1980) Legitimação pelo Procedimento, Ed. UnB.

Madalena, P. (1995) "Juizado Especial Cível e Criminal”, Revista dos Tribunais, vol. 722.

MANCUSO, R.C. (1983) "Contribuição para uma análise crítica do anteprojeto sobre o Juizado Especial de Pequenas Causas", Revista dos Tribunais, vol. 573.

MERRY, S. E. (1990) Getting Justice and Getting Even: Legal Consciousness Among Working-Class Americans, University of Chicago Press.

MirabeTE, J. F. (1996) “A representação e a lei 9.099/95”, Revista dos Tribunais, vol. 726.

MirANDA RosA, F.A. (1981) "Justiça de Paz: uma instituição desperdiçada", Separara da Revista de Jurisprudência do TJERJ, 10.
MORAES, S.C. (1998) Juizado Especial Cível, Editora Forense.

NoGUEIRA, A. P. F. (1994) "O acúmulo de recursos nos tribunais e a solução emergencial com o Juizado Especial de Causas de Menor Complexidade", Revista dos Tribunais, vol. 708.

NogueIRA, P. L. (1996) Juizados Especiais Cíveis e Criminais, São Paulo, Saraiva.

OliveIRA, J. (1985) Juizado Especial de Pequenas Causas, Série Legislação Brasileira, Saraiva.

REIS, A. (1982) "O processo das pequenas causas: história da ia experiência", AJURIS, 9 (26).

RodRIGUES, F.C.P. (1987) "Perspectivas do Juizado de Pequenas Causas", R.T. , vol. 618.

SADEK, M.T., ARANTES, R.B. (1994) "A Crise do Judiciário e a Visão dos Juízes”, Revista USP, 21: 34-45.

SAlvadOR, A.R.S. (1990) "O Juizado Especial de Pequenas Causas: obrigatória sua criação e absoluta sua competência”, R.T., vol. 660.

SiLva, O. B. (1985) Juizado de Pequenas Causas, Porto Alegre, Letras Jurídicas Editora Ltda.

SOARES, N. S.(1996) Juizado Especial Cível: A justiça na Era Moderna, Etr Ed. Ltda.

Souza Santos, B., Marques, M. M. L., Pedroso, J. (1996) "Os Tribunais nas Sociedades Contemporâneas", Revista Brasileira de Ciências Sociais, 30: 29-62.

Watanabe, K. (1985) Juizado Especial de Pequenas Causas, Ed. Revista dos Tribunais.

Watanabe, K. (1985) "Juizado Especial de Pequenas Causas: Filosofia e Características Básicas” Revista dos Tribunais, vol. 600.

WisSLER, R.L. "Mediation and Adjudication in the Small Claims Court: The Effects of Process and Case Characteristics", (1995), in Law \& Society Review, Vol. 29, Number 2. 


\section{O MINISTÉRIO PÚBLICO E A CONSTITUINTE DE 1987/88*}

\section{Fábio Kerche}

No Capítulo referente ao Ministério Público tenho a impressão de que demos um passo - e, se isso for aceito pela Casa, histórico. Trata-se de um passo histórico e até de repercussões teóricas muito importantes porque estamos criando outro órgão no esquema dos três Poderes. É um órgão fiscalizador que não se pendura em qualquer dos ramos do esquema de Montesquieu. Por que propormos a autonomia financeira, política e administrativa do órgão? Porque queremos um fiscal forte da lei. Plínio de Arruda Sampaio (PT-SP), na sétima reunião ordinária da Subcomissão do Poder Judiciário e do Ministério Público na Assembleia Nacional Constituinte de 1987/88.

\section{Introdução}

O objetivo deste artigo é apresentar possíveis explicações do por que da aprovação, durante os trabalhos da Assembleia Nacional Constituinte de 1987/88, de um Ministério Público independente de todos os Poderes de Estado e com atribuições que extrapolam a persecução penal. O debate será travado com aqueles - entre os quais se inclui uma parcela significativa da instituição - que acreditam que os constituintes não possuíam a dimensão exata do que estavam aprovando. Muitos julgam que o lobby organizado pela Confederação Nacional do Ministério Público "enganou" os parlamentares ou que os constituintes "cochilaram" no momento da aprovação deste projeto. Sustento, diferentemente, que a hipótese "cochilo" não explica todo o processo e não reflete a complexidade dos trabalhos da Constituinte (65.000 emendas, 243 advogados entre os 559 parlamentares das mais diversas posições políticas, quase dois anos de atividades etc.).

O texto da Constituição e a Assembleia Nacional Constituinte caracterizaram-se por vários aspectos que permitem afirmar que o

\footnotetext{
* Esta é uma versão resumida da minha dissertação de mestrado, orientada pela Professora Doutora Maria Tereza Sadek, defendida no Departamento de Ciência Política da USP em 1998. Uma versão preliminar deste artigo foi publicada na Revista Brasileira de Ciências Criminais. Gostaria de agradecer os Professores Doutores José Reinaldo de Lima Lopes e Marcus Faro de Castro pela participação na banca. (NUNES, Fábio José Kerche, $O$ Ministério Público e a Constituinte de 1987/88).
}

Ministério Público, entendido prioritariamente como um defensor independente dos direitos da sociedade, não é um fato destoante de todo o resto do diploma constitucional. Pelo contrário: é fruto de elementos de cultura política e de um determinado contexto histórico-político, refletidos em vários pontos da Constituição, que permitiu que o lobby da Confederação Nacional do Ministério Público obtivesse sucesso - leia-se sucesso parcial - na aprovação de sua proposta. Dessa forma, a Assembleia Nacional Constituinte serviu como uma espécie de "filtro" às propostas apresentadas, criando inclusive mecanismos de limitação e controle por parte de outros Poderes de Estado não previstos na proposta da Confederação Nacional do Ministério Público (Conamp). Em outras palavras: a Conamp pode se sentir vitoriosa, não porque "enganou" os sonolentos parlamentares, mas sim porque apresentou uma proposta que não era contrária aos elementos balizadores dos debates, que ia positivamente ao encontro de aspectos conjunturais e de cultura política presentes na Assembleia Nacional Constituinte. E é somente na interação desses elementos que se torna possível entender o processo de aprovação deste "novo" Ministério Público.

Este artigo está dividido em duas partes. Na primeira, há uma análise institucional do Ministério Público aprovado pelos constituintes de 1987/88. O objetivo é demonstrar que o Ministério Público brasileiro é uma novidade quando são observados conjuntamente dois pontos: por um lado, a independência ou autonomia frente aos Poderes de Estado e, por outro, seu papel de agente privilegiado para propor a ação civil pública. A segunda parte apresenta a discussão do por que da aprovação de tal projeto pela Assembleia Nacional Constituinte. Minha hipótese, baseada em elementos conjunturais e de cultura política, é um contraponto à explicação do suposto "cochilo".

\section{O Ministério Público brasileiro}

O Ministério Público pode ser considerado, do ponto de vista institucional, a maior novidade trazida pela Constituição de 1988, mesmo quando comparado aos Poderes de Estado ou outras instituições como o Exército ou o Banco Central. Ou seja, mesmo com modificações, as atribuições básicas dessas instituições e Poderes foram mantidas. De fato, o Legislativo continuou bicameral; o Executivo manteve suas atribuições administrativas e preservou grandes poderes para legislar; o Banco Central 
permaneceu ligado ao Poder Executivo. Quanto ao Ministério Público, entretanto, há um claro ponto de inflexão. Antes de 1988, tratava-se de uma instituição ligada ao Executivo, responsável principalmente pela ação penal pública junto aos tribunais. Após a Constituição de 1988, o Ministério Público passa a ser independente de todos os Poderes de Estado e detentor de atribuições extremamente reforçadas de representante da sociedade, inclusive para questões coletivas de fundo civil, através da ação civil pública.

O significado da ação civil pública e da independência ou autonomia do Ministério Público merecem uma apreciação mais detida.

\section{A ação civil pública}

A ação civil pública é um instrumento jurídico que permite a representação, junto ao Judiciário, de interesses coletivos, difusos e individuais homogêneos. Além do Ministério Público, também a União, os Estados, os Municípios, as autarquias, as empresas públicas, as fundações, as sociedades de economia mista e as associações existentes há pelo menos um ano com objetivos de defesa do meio ambiente, do consumidor ou do patrimônio histórico e cultural, podem lançar mão de tal mecanismo. Por este motivo, pode-se afirmar que o MP detém uma legitimidade concorrente, mas não exclusiva no que se refere à ação civil pública (MANCUSO: 1994). Mesmo não sendo monopólio do MP, como é a ação penal, a instituição tem se configurado como o agente privilegiado para utilizá-la, tornando-se responsável, segundo Ada Pelegrini Grinover, por 90\% das ações desse tipo (SADEK: 1997).

A criação desse instrumento jurídico ocorreu em 1981 com a Política Nacional do Meio Ambiente e foi incrementada durante quase toda a década de 80. Em 1985, "a Lei 7347 regulamentou com precisão esse novo tipo de ação (...) definindo seu objeto, o foro competente, a legitimação para utilizá-la, as atribuições do Ministério Público etc.” (ARANTES: 1997; p. 03). Mas foi a Constituição de 1988 que ampliou o número de questões que poderiam ser levadas a juízo através desse mecanismo, incumbindo o Ministério Público da promoção da ação civil pública para a proteção da sociedade no que diz respeito aos "interesses difusos, coletivos e individuais indisponíveis e homogêneos".
A grande questão do ponto de vista do potencial raio de ação do MP é que a concepção desses interesses difusos, coletivos e individuais homogêneos é muito ampla e pouco regulamentada do ponto de vista legal. Vai desde o direito à escola, à saúde até a proteção do meio ambiente, sem que, contudo, exista uma legislação infraconstitucional disciplinando todos os seus aspectos.

Essa amplitude, somada à falta de regulamentação, permite que o Ministério Público atue em questões tradicionalmente reservadas aos agentes políticos. Ou seja, há, ou poderia haver, em caso de empenho, uma espécie de "substituição" dos representantes eleitos pelos representantes ligados ao Ministério Público e legitimados por outros mecanismos que não os eleitorais. Neste sentido, a instituição se utiliza (identificando que há espaço para atuar), e contribui (selecionando as mais diversas questões) para a "politização da justiça" ou "judicialização da política".

A judicialização da política é um fenômeno, segundo Marcus Faro de Castro, baseado em dois pontos: o primeiro é "um novo ativismo judicial", isto é, uma nova disposição de tribunais judiciais no sentido de expandir o escopo das questões sobre as quais eles devem formar juízos jurisprudenciais (muitas dessas questões até recentemente ficavam reservadas ao tratamento dado pelo Legislativo ou pelo Executivo) (...) (CASTRO: 1997; p. 148). O segundo fenômeno é gerado pelo "interesse de políticos e autoridades administrativas em adotar (a) procedimentos semelhantes aos processos judiciais e (b) parâmetros jurisprudenciais em suas deliberações" (muitas vezes, o Judiciário é politicamente provocado a fornecer esses parâmetros) (Idem). Segundo o autor, a judicialização da política - não exclusiva do Estado brasileiro - é consequência da ampliação da proteção dos direitos após a II Guerra Mundial e a diminuição da eficácia de políticas macroeconômicas no final dos anos 60 .

Para o caso específico do Brasil, Sadek e Arantes discutem a ampliação do papel institucional do Poder Judiciário, principalmente após a Constituição de 1988. O Judiciário tem atuado como árbitro em um número cada vez maior de questões, não mais se restringindo meramente a conflitos de interesses individuais, como reza o modelo clássico de liberalismo. Tal modificação provocaria alterações no sistema político como um todo. Afirmam eles que: 
a performance institucional dos três poderes, muito mais do que orientada por um modelo de separação e divisão de responsabilidades, tem sido impulsionada por um sistema que estimula multivetos. Cada poder tem força suficiente para impedir o outro de agir, e disso não escapa o Judiciário. Ao contrário, além de constante árbitro de disputas entre os outros dois poderes, sua estrutura descentralizada e, de fato, federativa, permite-lhe paralisar políticas, proferir decisões sem uniformidade e, assim, suspender, ainda que temporariamente, medidas de impacto nacional (SADEK \& ARANTES: 1994; p. 37).

O Judiciário é um Poder "inerte", só podendo agir quando provocado por um terceiro. Face a este constrangimento, o Ministério Público é o agente privilegiado para tal tarefa, contribuindo de maneira decisiva para selecionar casos para a apreciação dos tribunais. Ou seja, a politização do Judiciário é um fenômeno que existe independente do Ministério Público, contudo, é potencializado por esse agente da própria estrutura do Estado que pode abrir inquéritos e propor ações, inclusive sobre questões de fundo civil.

Se antes, como reza a tradição liberal-democrática, normas programáticas tinham de ser invocadas pela sociedade no terreno da luta política, hoje, de acordo com a Constituição, elas podem e têm sido levadas aos Tribunais por obra principalmente do Ministério Público. Enquanto a sua execução dependia em geral da vontade do governante, mediante os incentivos e constrangimentos próprios do processo político, agora a execução pode ser cobrada do Poder Público por um órgão do próprio Estado numa instância não política de resolução de conflitos: a instância judicial (ARANTES: 1997; p. 08).

As normas programáticas às quais o autor se refere são aquelas contidas na própria Constituição e utilizadas, muitas vezes, pelos integrantes do Ministério Público para justificar suas ações civis. Assim, por exemplo, quando um promotor exige que uma determinada escola não seja fechada, ele pode estar baseando-se no princípio constitucional de que a educação é um direito social. O problema é que, como demonstra Faoro, algumas constituições - acredito que a de 1988 seja um exemplo - são como "cartas de intenções". Ou seja, as constituições nominais são reflexo de uma "desarmonia entre a situação de fato - a constituição social - e as normas constitucionais, tidas por prematuras, na versão conhecida da menoridade do povo. Com o tempo, pelo desenvolvimento de condições reais, a constituição viria a ser aplicada, reduzida, no presente, a um manual educativo" (FAORO: 1985; p.11). Uma Constituição, dessa forma, não se resume a um conjunto de Leis, mas aponta para um caminho a ser seguido pelos sucessivos Governos e governantes. É como se a Carta Constitucional, usando uma imagem do próprio autor, fosse uma roupa esperando que a tirassem do armário. A questão é: quem seria o responsável por fazer com que a roupa sirva com perfeição, transformando a Constituição nominal em normativa?

No modelo clássico de liberalismo há uma clara diferenciação entre Estado e sociedade civil. Um funciona como limite do outro. Neste sentido, a sociedade civil surge onde o Estado não ocupa espaço. É na sociedade que aparecem as demandas (input) que o sistema político deve procurar dar conta (output). E os partidos políticos são o principal elo de ligação das demandas da sociedade para o Estado, não sendo, nesse sentido, nem membros da sociedade civil nem do Estado (BOBBIO: 1995). Funcionam como ponte entre os dois lados, apresentando propostas de como transformar a "carta de intenções" em "regras de fato". E mais: selecionam, através do debate público e das eleições, quais são as prioridades, já que essa transformação não é imediata, sofrendo limitações variadas, como, por exemplo, as orçamentárias. O Estado, por sua vez, tanto deve ser contido para que as relações econômicas, sociais, religiosas aconteçam com liberdade na esfera da sociedade como, por outro, deve ser estimulado para que forneça respostas a eventuais problemas. Esse, segundo Fábio Wanderley Reis, seria o paradoxo do liberalismo:

(...) se implantar a democracia requer a juridificação das relações sociais, segue-se que a democracia requer também inapelavelmente construção do Estado, de um Estado que possa representar a garantia da vigência das regras correspondentes. Assim, por contraste com a formulação usual do ideal liberal, em que o Estado surge como algo a ser antes de mais nada contido em nome das 'liberdades liberais' (...) esta nova perspectiva vê no Estado algo a ser construído de maneira adequada - e o êxito do processo de construção institucional do Estado aparece como condição mesmo para sua contenção naqueles aspectos em que tal contenção se faça necessário. Numa palavra, não é possível (...) edificar o estado de direito sem o esforço positivo de construir adequadamente o Estado tout court (REIS: 1988; p. 125). 
A novidade criada pelos constituintes de 1987/88 é que o Ministério Público - órgão estatal -, em alguns casos, pode fazer a ligação descrita entre sociedade civil e Estado, sem deter a legitimidade tradicional do voto e do debate político, através do inquérito civil e da ação civil pública. Nesse sentido, não pode ser considerado uma instituição típica do modelo liberal em sua acepção clássica, ainda que, utilizando a "técnica liberal" de defesa de direitos previstos constitucionalmente através do Poder Judiciário. Seu formato e, sobretudo suas atribuições reforçam ao extremo o que seria o paradoxo do liberalismo. O ponto central a ser destacado é muito mais a potencialidade da instituição de atuar como agente detentor de grandes poderes, inclusive sua capacidade de transferir debates tradicionalmente da esfera política para a Justiça. Assim, ainda que não seja intuito deste artigo um levantamento sistemático da atuação do Ministério Público ou mesmo o estudo de casos relevantes, pode-se lembrar, nesse sentido, da tentativa de barrar a distribuição de seringas para viciados em drogas em Santos, a indenização para os usuários dos trens de subúrbio na grande São Paulo, mudanças nos índices de reajuste para os mutuários do Sistema de Habitação no Mato Grosso, pedidos de liminares para obrigar a prefeitura de São Paulo abrigar crianças de rua etc. Esses temas constituem itens de políticas públicas (saúde, transporte, habitação etc.) e não são meramente jurídicos. Se o sistema de "multivetos" pode paralisar a capacidade de ação dos Poderes de Estado, o Ministério Público é mais um agente - sem a legitimidade do voto e do apoio de segmentos da sociedade - para agravar tal situação.

Mas é somente na conjunção da ação civil pública e da independência institucional que isso tem condições de ocorrer. Se o Ministério Público não tivesse a autonomia - supondo, por exemplo, que o cargo de Procurador-Geral permanecesse de confiança do Executivo, ou que o promotor tivesse que obedecer recomendações hierárquicas - ações civis contra o Governo seriam praticamente inviáveis. Por outro lado, se o Ministério Público não fosse o agente privilegiado para acionar a Justiça através do poderoso mecanismo da ação civil pública, mesmo com a independência que goza hoje, seu campo de influência política seria restrito à ação penal e, consequentemente, limitado. Portanto, é a junção dessas características - ação civil pública e autonomia - que torna o Ministério Público uma instituição fundamental no jogo político.

\section{Autonomia do Ministério Público}

Todos os Estados possuem um corpo de advogados, relativamente fixo, responsável pela ação penal. Diferente das ações civis, geralmente propostas ao Judiciário pelos próprios cidadãos através de advogados, a ação penal é monopólio de uma instituição estatal que pode ser denominada genericamente de Ministério Público. Afinal, o Estado moderno, detentor do monopólio do uso legítimo da violência física, deve punir aqueles que lançam mão da violência sem sua autorização. Em outras palavras, se é o monopólio da violência que diferencia o Estado de outros agentes e instituições, é também característica e particularidade desse Estado ter o direito de penalizar os cidadãos que rompem esse monopólio. E é o Ministério Público - juntamente com a polícia por um lado e o Poder Judiciário por outro - uma das instituições responsáveis por esta função.

Se esse é o ponto comum entre os Ministérios Públicos de vários países, existem, contudo, variações institucionais significativas: desde a localização dessa instituição na estrutura do Estado, até sua relação com a polícia, passando por diferentes formas de seleção de seus quadros. Para os objetivos deste artigo, tratarei de salientar que existem dois modelos básicos (com uma pequena, porém importante, variação no primeiro modelo) quando isolada a variável da relação do Ministério Público com o controle político. A escolha desta variável tem sua razão de ser: ela que condiciona fortemente todas as demais.

- Ministério Público controlado politicamente: modelo mais comum de Ministério Público é aquele em que a instituição é ligada ao Poder político stricto-sensu (Poder Executivo ou Legislativo, conforme o Sistema de Governo). Ou seja, o Ministério Público é um braço, como a polícia, da função executiva do Estado. Como exemplo, temos o Ministério Público inglês, o francês, o alemão, o canadense, o espanhol, o Ministério Público Federal norte-americano e os Ministérios Públicos, italiano e brasileiro, antes de suas Constituições democráticas. A instituição é controlada pelo Ministro da Justiça, que tem o dever de dar respostas relativas à atuação do Ministério Público para a sociedade e para a classe política. Neste sentido, o Ministério Público baseado nesse modelo sofre o accountability $^{1}$ horizontal

${ }^{1}$ Segundo O'Donnell, o accountability horizontal é “(...) uma rede de poderes relativamente autônomos (isto é, outras instituições) que têm a capacidade de questionar, e eventualmente 113 
principalmente por parte do Governo e, indiretamente, o accountability vertical, por parte dos eleitores que escolhem o Governo. Assim, o Poder político pode interferir em questões como a escolha de prioridades (crime organizado ou narcotráfico, por exemplo) ou mesmo eventualmente orientar as atuações sobre casos em particular.

Esse controle por parte do Governo pode ser exercido de maneiras distintas. Em alguns países, como nos Estados Unidos, os promotores federais são indicados pelo grupo que controla o Poder Executivo; consequentemente, a mudança de Governo significa também a mudança dos quadros que compõem o Ministério Público. Nesse caso, o promotor, em todas as instâncias, exerce um cargo de confiança e é passível de demissão quando o Governo acreditar que não está cumprindo devidamente suas obrigações.

Outra forma de controle político se dá em relação ao Ministério Público organizado, digamos assim, burocraticamente. Nesse caso, os promotores possuem certa estabilidade e os mecanismos de controle por parte do Governo são distintos do modelo norte-americano. Na França, por exemplo, mesmo com a "liberdade de palavra", que garante ao promotor, liberdade de atuação durante o processo, sua carreira pode ser prejudicada caso não siga as orientações emanadas da hierarquia, já que é o Conselho Superior da Magistratura - controlado pelo Ministro da Justiça - o órgão responsável pelas promoções. A fidelidade às posições defendidas pelo Governo é mantida por este instrumento. Outra forma de controle, ainda neste modelo, é encontrada no caso espanhol. O Promotor Geral, que possui a capacidade de interferir sobre qualquer assunto tratado pela instituição, é o único indicado pelo Governo. Desta forma, é através desta indicação que se torna possível o controle de toda a estrutura do Ministério Público por parte do Governo.

Portanto, o que caracteriza o modelo acima é que o Ministério Público desses países são 1) estruturas controladas pelo Governo e, em última análise, pelos eleitores desses Governos; 2) seus agentes não

punir, maneiras 'impróprias' de o do cargo em questão cumprir suas responsabilidades" (O’DONNELL:1991; p.32). Já o accountability vertical é aquele realizado pela própria sociedade, através do voto, por exemplo. exercem um cargo político, mas burocrático ${ }^{2}$, e 3) a ação penal não se resume a uma questão técnica, mas também pode sofrer interferências do jogo político-partidário.

Vale a pena observar o que se passa quando não há a presença simultânea das três características. O Ministério Público distrital norteamericano não é ligado a nenhum Poder de Estado, entretanto, sofre accountability por parte dos eleitores sem a intermediação do Governo. Na maioria das cidades americanas, os promotores são eleitos diretamente pelos munícipes. Neste sentido, o accountability horizontal é fraco (restrito ao Judiciário que é o Poder que julga a ação), mas, em contrapartida, o accountability vertical é forte e direto, não passando pela "intermediação" do Ministro da Justiça e do Governo, como nos casos discutidos anteriormente. O promotor lança seu nome no jogo político partidário e, respeitando a lógica eleitoral, deve atender aos interesses de seus eleitores para um eventual segundo mandato. A escolha de prioridades é, ao menos teoricamente, mais fortemente marcada por opções políticas do que no modelo anterior.

Em suma: o que permite agrupar instituições tão diferentes na sua organização como os Ministérios Públicos dos Estados Unidos, França ou Espanha é que a ação penal não é simplesmente uma questão técnica, mesmo quando exercida por burocratas, mas sofre algum tipo de controle político. Devido aos mecanismos de accountability descritos, o jogo político-partidário assume papel de primeira grandeza ao se analisar a aplicação da ação penal e a estrutura desses Ministérios Públicos.

${ }^{2}$ Estou utilizando a clássica distinção de Max Weber: "O verdadeiro funcionário (...) não deve fazer política exatamente devido a sua vocação: deve administrar, antes de tudo, de forma não partidária. (...) Ele deve desempenhar sua missão sine ira et studio, 'sem ressentimentos e sem preconceitos'. Não deve, em consequência, fazer o que o homem político, seja o chefe, sejam seus seguidores, está compelido a fazer incessantemente e necessariamente, isto é, combater. Com efeito, tomar partido, lutar, apaixonar-se. A atividade deste último está subordinada a um principio de responsabilidade totalmente estranho, e mesmo oposto, ao que norteia o funcionário". E completa: "O funcionário deve executar essa ordem como se ela correspondesse a suas próprias convicções. (...) A honra do chefe político, ao contrário, consiste justamente na responsabilidade pessoal exclusiva por tudo quanto faz, responsabilidade que ele não pode rejeitar, nem delegar" (WEBER: 1972; pp. 78/79). O promotor, nos casos discutidos até o momento, aproxima-se mais do burocrata (a responsabilidade de seus atos recai, em última instância, no político que controla a instituição e que seleciona as prioridades) do que do político. 
- Ministério Público não controlado politicamente: o segundo modelo de Ministério Público é aquele que sofreu um processo de "despolitização". Ou seja, são Ministérios Públicos que, na sua construção institucional, foram retirados do controle do Governo. Ou passaram para as mãos do Judiciário (como é o caso italiano) ou tornaram-se independentes de todos os Poderes de Estado (como é o caso brasileiro). O aspecto "técnico" da acusação penal é ressaltado e a escolha de prioridades não é fruto da opção políticapartidária. Em outras palavras, retira-se a instituição da influência da esfera política transferindo-a para uma esfera técnica ou burocrática. Não parece ser coincidência que os dois exemplos citados referem-se a países que sofreram rupturas democráticas e o eventual mau uso por parte dos Governos não democráticos "empurrou" a instituição para esta autonomia. É importante destacar também que o reforço do aspecto técnico da acusação penal tem duas consequências: a primeira é o deterioramento dos mecanismos de accountability por parte da sociedade ou do próprio Governo. No caso italiano, onde o MP e juízes formam o mesmo corpo, o caso é agravado porque a própria instituição que acusa também julga, garantindo grandes poderes aos magistrados italianos. $\mathrm{O}$ caso brasileiro é distinto, pelo menos neste ponto, porque o Poder Judiciário é justamente uma das poucas formas de controle do Ministério Público. A segunda consequência é que essa despolitização retirou a instituição do controle do Governo, mas garantiu liberdade para uma eventual politização interna da instituição. Como exemplo, basta lembrar a grande repercussão da "Operação Mãos Limpas" na Itália e a projeção dos promotores do caso, o grande número de magistrados que lançam seu nome na disputa eleitoral italiana ou a atuação do Ministério Público brasileiro em questões coletivas.

Portanto, o que caracteriza esse segundo modelo é que o Ministério Público desses países são 1) estruturas não controladas pelo Governo, ou seja, o controle político eleitoral não existe ou pelo menos não é importante; 2) seus agentes não exercem um papel exclusivamente burocrático, já que a responsabilidade de seus atos recai sobre eles mesmos ou sobre o Ministério Público como um todo e não sobre o Governo, e 3) a ação penal, aparentemente, é uma questão mais técnica do que política.

Mas não é apenas esta variável "macro" que merece comentários para o caso brasileiro. Como consequência dessa independência institucional, há também a independência de cada promotor ante o próprio
Ministério Público. Os mecanismos de controle são excepcionais e frágeis. O princípio do "promotor natural", a efetividade no cargo após dois anos de serviços, a garantia de ampla defesa perante o Colégio de Procuradores e ao Poder Judiciário, a inamovibilidade etc., garantem a liberdade de atuação mesmo em relação a orientações ditadas pelo Procurador Geral - que também não responde a qualquer poder hierárquico - e se transforma quase em uma opção pessoal do integrante do Ministério Público segui-las ou não. Em outras palavras, mecanismos de defesa criados para proteger os integrantes do Ministério Público contra injunções políticas como as realizadas no passado acabam garantindo uma independência inclusive contra o "saudável" controle entre Poderes e instituições necessário à democracia. Dessa forma, são débeis os mecanismos de accountability vertical e mesmo horizontal.

Essa liberdade, combinada com o alto grau de dificuldade de se garantir uma política institucional decidida pelo próprio Ministério Público, pode permitir que integrantes do MP atuem de forma não organizada, acentuem o individualismo, repassem informações para a imprensa ou posicionem-se publicamente sobre os mais variados assuntos. Desta forma, a atuação dos integrantes do Ministério Público, muitas vezes, não se restringe nem mesmo aos instrumentos jurídicos - que já são bastante poderosos - mas é ampliada, alcançando também o "plano das ações políticas ou nãojurisdicionais" que seriam as ações "definidas pelo exercício informal (ou institucionalmente marginal) do poder" (CASTRO:1997; p.149). Neste sentido, o papel de burocrata como um executor das decisões tomadas na esfera política é transformado e os membros da instituição detêm liberdade para "tomar partido, lutar, apaixonar-se", como disse Weber em relação ao político.

Mas mesmo sendo insuficientes, quais são os mecanismos de accountability?

Há três tentativas básicas de criar-se mecanismos de accountability decididas pelos constituintes de 1987/88. Por um lado, o próprio Poder Judiciário. Afinal, é o Ministério Público que propõe a ação, mas quem a julga são os juízes. Este mecanismo é fragilizado pela atuação acima descrita, ou seja, a liberdade do promotor ou procurador de posicionar-se publicamente. Imaginemos, por exemplo, a situação de um prefeito processado pelo Ministério Público estadual. A atuação do promotor 
responsável pelo caso pode não se restringir ao processo junto ao Poder Judiciário. Eventualmente este promotor possui liberdade institucional para acusar o prefeito publicamente através da imprensa. Ora, para um político isto pode ser devastador. A questão é que a ação, neste exemplo, ainda não foi julgada e o prefeito é transformado em culpado perante a opinião pública por um agente do Estado.

Outro mecanismo de accountability é a indicação do Procurador Geral da República e os Procuradores Gerais de Justiça dos Estados. O primeiro é indicado pelo Presidente da República, entre os membros de carreira, com aprovação do Senado. Já o Procurador Geral de Justiça é indicado pelo Governador do Estado a partir de uma lista tríplice votada pelos próprios promotores e procuradores do Ministério Público estadual. ${ }^{3}$ Este mecanismo mostra-se frágil por dois motivos. Primeiro porque, como vimos, os Procuradores Gerais são mais chefes "administrativos" do que propriamente controladores da instituição. Ou seja, pelas garantias institucionais, o Procurador Geral possui poucos mecanismos para impor unia política institucional unificada. Não pode, por exemplo, interferir sobre casos em particular. O segundo problema é que os Procuradores Gerais possuem um mandato fixo, não podendo ser destituídos por questões políticas. Em outras palavras, o Procurador Geral não exerce um cargo de confiança do Executivo e nem possui autoridade para interferir nas atuações individuais dos integrantes do Ministério Público do qual é o "chefe".

Outra possibilidade de accountability seria aquela desenvolvida pelo modelo francês, ou seja, o controle das promoções. Este mecanismo também é enfraquecido no caso do Ministério Público brasileiro. Os mecanismos de promoção resultam de dois critérios: "merecimento" e "antiguidade". Neste sentido, o primeiro permite uma interferência do Colégio de Procuradores e, consequentemente, um eventual estímulo para a criação de uma política institucional. O segundo é praticamente independente da interferência política da instituição, garantindo a promoção de maneira quase automática depois de determinado tempo de serviço. Assim, mesmo o controle anteriormente definido como "burocrático" não é suficiente para garantir uma linha única de atuação.

\footnotetext{
${ }^{3}$ A escolha direta da lista tríplice por parte dos promotores e procuradores não consta da Constituição.
}

É claro que estes mecanismos não são completamente estéreis. O Poder Judiciário pode absolver o acusado, comprovando sua inocência. Por outro lado, somente os Procuradores Gerais podem acusar o primeiro escalão do Executivo nacional e dos estados. A dependência da indicação dos chefes dos Executivos (inclusive para um segundo mandato) pode limitar a independência do Procurador Geral, preservando a figura do Presidente e dos Governadores.

Devido a estas ressalvas, seria melhor falar em "autonomia" do Ministério Público do que em "independência" ". De qualquer maneira, os mecanismos de accountability são frágeis: por um lado, o horizontal quase não existe, por outro, o vertical, muitas vezes, mostra-se incapaz de limitar e controlar a atuação de promotores e procuradores. Soma-se a isto que, além do monopólio da ação penal e do papel do Ministério Público brasileiro como agente privilegiado para provocar o Poder Judiciário através do poderoso mecanismo da ação civil pública, a instituição é responsável por fiscalizar atos impróprios de outros Poderes, em especial do Poder Executivo. Ou seja, se os mecanismos de accountability em relação ao Ministério Público são frágeis e insuficientes, a instituição detém importante papel na rede de accountability relativas a outras instituições. A pergunta, portanto, permanece pertinente: quem controla os controladores?

\section{A Assembleia Nacional Constituinte e o Ministério Público}

O Ministério Público brasileiro, quando observado seu aspecto de independência institucional e o instrumento da ação civil pública, tornou-se não somente o caso mais extremo de parquet distante dos Poderes políticos quando comparado a outros países, mas também um caso único. E essas mudanças - independência perante o Executivo, defesa dos interesses coletivos, mandato assegurado para o Procurador-Geral etc. - foram garantidas a partir da Constituição de 1988. Assim, neste momento, cabe a seguinte questão: Por que os constituintes de 1987/88 optaram por esse modelo um tanto distinto do observado na maioria dos países democráticos?

${ }^{4}$ Comentando o caso dos Bancos Centrais, Sola, Garman e Marques (1997; p.7) escrevem: "We note, however, many make the distinction between autonomy and independence. While the latter refers to a severance from the political arena, the former indicates the ability to resist short-term political pressures. Independents never really exist in practice”. Para Dahl (1982), entretanto, os termos são intercambiáveis. 
Uma das características fundamentais que distingue a feitura da atual Constituição brasileira foi justamente a grande abertura a vários grupos de pressão representando interesses diversos. Desde o princípio dos trabalhos, os constituintes organizaram-se para ouvir diversos segmentos da sociedade. A Subcomissão do Poder Judiciário e do Ministério Público, que foi responsável pelas primeiras propostas sobre o MP na Constituinte, recebeu oficialmente, além da própria Confederação Nacional do Ministério Público, representantes dos Defensores Públicos e dos Delegados de Polícia. Pode-se questionar por que o Ministério Público recebeu as maiores modificações. Ou seja, se todos fizeram lobby, por que foi justamente esta instituição que mais viu ampliada suas atribuições?

Minha hipótese é que a aprovação deste modelo de Ministério Público se deve a dois aspectos. Por um lado, e este é o pressuposto, verificou-se, de fato, uma eficiente organização da Confederação Nacional do Ministério Público que ofereceu aos constituintes uma proposta em forma de texto constitucional (a "Carta de Curitiba") sobre a inclusão do parquet na Constituição e desenvolveu um trabalho de acompanhamento junto às discussões constituintes (lobby) que se mostrou eficaz. Por outro, houve relativa facilidade para esse lobby operar "vendendo" aos constituintes a ideia da importância da criação de um agente não político ou pelo menos, não político partidário - responsável pela defesa de interesses da sociedade. Essa relativa facilidade se deve a um aspecto conjuntural e a características de cultura política.

$\mathrm{O}$ aspecto conjuntural refere-se à própria época em que os trabalhos da Assembleia Nacional Constituinte se desenvolveram: o fim de um período autoritário- militar que durou mais de 20 anos (1964-1985). A questão central para os constituintes, observando a Constituição de 1988, não era minimizar o Estado segundo os parâmetros liberais clássicos, mas, sim, democratizá-lo. Essa afirmação pode ser corroborada observando-se vários aspectos como a ampliação dos direitos coletivos, mecanismos de participação direta (referendum, plebiscito, iniciativa popular), entre outros. Outra forma de reforçar esse argumento é recorrer a um dos trabalhos de Maria D’Alva Kinzo sobre o processo Constituinte (1990). Buscando classificar a atuação dos partidos políticos no período da feitura da Constituição, a autora agrupou votações de acordo com conteúdos comuns: "governismo", "conservadorismo", "democratismo" 5, "nacionalismo" e "oposição ao sistema financeiro". Trabalhando com médias e medianas, a autora chegou aos seguintes resultados:

Tabela 1

Médias e Medianas de Alguns Partidos/Grupos Políticos na Constituinte, Segundo suas Votações em Primeiro e Segundo Turnos*

Partidos/grupos Governismo Conservadorismo Democratismo Nacionalismo Oposição

\begin{tabular}{cccccc} 
& & & & Finan. \\
\hline \multirow{2}{*}{ Centrão } & A**: 8.6 & A: 7.9 & A: 4.0 & A: 1.7 & A: 1.7 \\
& B***: 1.0 & B: 8.0 & B: 3.8 & B: 0.0 & B: 1.1 \\
\hline \multirow{2}{*}{ PFL } & A: 7,9 & A: 7.2 & A: 4.8 & A: 2.1 & A: 1.4 \\
& B: 8,0 & B: 7.7 & B: 5.0 & B: 0.0 & B: 0.0 \\
\hline \multirow{2}{*}{ PT } & A: 0.0 & A: 0.5 & A: 10.0 & A: 10.0 & A: 10.0 \\
& B: 0.0 & B: 0.5 & B: 10.0 & B: 10.0 & B: 10.0 \\
\hline \multirow{2}{*}{ PDT } & A: 2.0 & A: 0.4 & A: 9.7 & A: 9.6 & A: 9.4 \\
& B: 2.0 & B: 0.0 & B: 10.0 & B: 10.0 & B: 10.0 \\
\hline
\end{tabular}

Fonte: KINZO: 1990

* sem levar em conta as mudanças nos números de membros **média (0a 10)***mediana (0 a 10)

É interessante notar que, nos itens "Governismo", "Conservadorismo", "Nacionalismo" e "Oposição ao Sistema Financeiro", a diferença entre os partidos de esquerda e os de direita é relativamente maior do que no item “democratismo". Assim, por exemplo, o Centrão possui média 8.6 no que se refere ao apoio ao Governo enquanto o PT 0.0 E isso pode ser observado em todos os itens, com exceção do apoio às medidas democratizantes, onde essa diferença apresenta a menor variação (de 4.0 (PFL) a 10.0 (PT)). Ou seja, mesmo o partido ou grupo político com maior resistência a medidas democratizadoras não se distancia tanto, quando comparado aos outros itens, do mais favorável a elas indicando, assim, a prevalência da

\footnotetext{
5 As medidas democratizantes são as seguintes: a) Mandato de Segurança Coletivo; b) Democracia Direta (plebiscito, referendo etc.); c) Medidas de Fortalecimento do Congresso; d) Veto à intervenção das Forças Armadas em questões internas; e) Contrário à Introdução da Pena de Morte e f) Contrário à Censura Artística. Mais detalhes sobre todos esses dados em KINZO: 1990.
} 
tendência democratizante da Assembleia Nacional Constituinte. Isto se reflete também na construção do novo Ministério Público.

Quanto ao aspecto de cultura política, segundo Amaury de Souza e Bolívar Lamounier, pode-se identificar no processo constituinte de 1987/88 "três diferentes 'estratos' de experiência histórica, três "idades geológicas", (SOUZA \& LAMOUNIER: 1990; p. 83) da cultura política brasileira que estariam presentes nos debates e, consequentemente, nas leis elaboradas. $\mathrm{O}$ primeiro aspecto seria uma "negação indiscriminada do passado". Ou seja, a identificação de que, dado que os direitos individuais da tradição liberal não foram suficientes para acabar com as desigualdades existentes em nossa sociedade, somado à figura fraca ou mesmo inexistente de indivíduo, seria necessária "a revisão das premissas individualistas do Direito brasileiro" (Idem; p. 87). Deste modo, além de manter as tradicionais garantias e direitos dos indivíduos, esses são ampliados para entidades coletivas. "A novidade maior", escreve João Gilberto Coelho a este respeito:

é a introdução da noção de 'direitos coletivos', embora no mesmo capítulo dos individuais. Esta diferenciação, se bem interpretada e desenvolvida, rompe uma tradição de ver o direito exclusivamente através do indivíduo e gera o das coletividades, autônomo, próprio e diferente. A compreensão desta nova categoria levará à revisão de códigos, legislações, procedimentos judiciais e institucionais (COELHO: 1989; p. 27)

Como segundo aspecto, o "legado getulista" também teria seu espaço na cultura política durante os trabalhos da Assembleia Nacional Constituinte. Por um lado, o presidencialismo, com fortes traços plebiscitários, somado a uma tradição nacionalista refletida em vários pontos da Constituição de 1988, como o monopólio do petróleo, a definição de empresa nacional etc. Por outro, uma ampliação dos direitos de cidadania, principalmente nos seus aspectos trabalhistas que, pela lógica liberal, reflete uma noção paternalista de Estado. Em outras palavras: o Estado é concebido como agente privilegiado, não somente do ponto de vista da iniciativa econômica, como também da construção da cidadania. Esta concepção condiz perfeitamente com a tradição segundo a qual a sociedade civil é vista como fraca e incapaz por si só de exigir o cumprimento - ou mesmo a ampliação - de seus direitos. O Estado continua, pois, a ser visto, por parcela significativa dos constituintes, como agente privilegiado, inclusive, para a construção da cidadania. Neste sentido permanecem os supostos desenvolvidos em boa parte da literatura sobre a formação do Estado brasileiro - de Sérgio Buarque de Holanda a Raymundo Faoro, passando por Vitor Nunes Leal e Francisco Weffort ${ }^{6}$.

Por fim, havia, ainda, segundo Souza e Lamounier, uma posição que advogava uma alternativa à participação política exclusivamente através da representação política via partidos políticos/parlamentares.

Deu(-se) ao principio participativo uma definição muito mais forte, colocando-o virtualmente em pé de igualdade com a democracia representativa. Os legisladores não apenas tornaram o principio participativo operante nos níveis Legislativo e Judiciário, como também o adotaram como norma programática no Poder Executivo, em diversas situações administrativas especificas (SOUZA \& LAMOUNIER: 1990: p.99)

Assim, o referendo, o plebiscito e a iniciativa popular foram previstos pela Constituição. Em relação ao Judiciário, houve a legitimação de agentes coletivos contrariamente à tradição individualista-liberal. Cria-se

\footnotetext{
${ }^{6}$ Sérgio Buarque de Holanda e Raymundo Faoro buscam em suas análises o elemento de continuidade do Estado brasileiro, ou a "linha vermelha" que une vários momentos da história do Brasil. O Estado patrimonial, caracterizado por uma sobreposição do Estado em relação a sociedade - e não uma divisão como no modelo liberal -, seria esse aspecto (HOLANDA:1991; FAORO: 1976). O Estado patrimonial cria suas demandas e as resolve dentro de sua própria esfera. Os mecanismos de conexão entre sociedade civil e o Estado não se dão na forma tipicamente liberal-clássica através de partidos políticos, seleção de lideranças pelo voto ou pressão popular. Aqueles que controlam o aparelho do Estado, o estamento burocrático, não devem ser confundidos com elites. Afinal, escreve Faoro, todos os governos são chefiados pelas minorias. A diferença é que nos sistemas "elitistas" a seleção se dá colhendo lideranças pressionadas de baixo para cima, e não, como no modelo patrimonialista, de cima para baixo. A população, as classes sociais, longe da indignação constante, também parece adaptar-se ao modelo. No lugar de lutar por uma participação no poder, luta por fatias de proteção do Estado patrimonial. No lugar da crítica, a resignação. Vítor Nunes Leal, e sua brilhante análise sobre o coronelismo, demonstra como se dava o acordo entre o poder privado e o poder público e a dependência dos governantes e dos "coronéis" em relação a esse arranjo. A população do campo, a grande maioria do país predominantemente agrário, dependia totalmente dos favores desse acordo (LEAL: 1978) Francisco Weffort analisa o populismo e o aspecto paternalista do arranjo político que estabelecia uma relação direta entre o governante e a população dependente, por um lado, e manipulada, por outro, principalmente no período de 1945 a 1964 (WEFFORT: 1989).
} 
instrumentos que prescindem de uma intermediação entre a sociedade civil e o Estado. Não de uma maneira "bonapartista" - na qual a não intermediação ocorre no sentido manipulativo do Estado em relação à sociedade - mas, em um sentido de reforço e de construção de uma cidadania não dependente.

É na articulação desses pontos que a segunda parte da hipótese ganha consistência, demonstrando a relativa facilidade encontrada pela Confederação Nacional do Ministério Público em "vender" seu projeto. O Ministério Público, neste sentido, 1) é um agente privilegiado da defesa dos interesses coletivos ("negação do passado"); 2) reforça o papel do Estado como agente privilegiado nas relações sociais, inclusive sob o aspecto paternalista ("legado getulista"); e, 3) é um instrumento de reforço da cidadania, rompendo o modelo liberal-clássico de representação política via partidos políticos. Ou seja, este projeto foi bastante "vendável" justamente porque se adaptava às diferentes concepções presentes na "democrática" Assembleia Nacional Constituinte. Ele se diferencia enquanto projeto não porque se apresentava enquanto concepção de um único grupo, mas por representar um modelo novo, diferenciado, perfeitamente justificado como necessário tanto para aqueles que queriam romper com o passado autoritário do país, quanto para aqueles que percebiam o Estado como agente (ainda) fundamental para a realização, inclusive, da cidadania e, finalmente, para aqueles que buscavam formas alternativas de participação e interferência no debate político e na defesa de interesses.

O Ministério Público, deste ponto de vista, é uma espécie de síntese dos vários aspectos que marcaram a feitura da Constituição de 1988.

\section{As propostas apresentadas}

Neste item, o objetivo é comparar os diferentes anteprojetos apresentados sobre o Ministério Público na Constituinte - oito anteprojetos da Relatoria Geral da Assembleia Nacional Constituinte ${ }^{7}$, o anteprojeto da

\footnotetext{
${ }^{7} \mathrm{O}$ que estou chamando de "anteprojetos do relator" é somente uma maneira de agrupar todos os projetos, substitutivos etc., colocados em discussão no plenário geral da Assembleia Nacional Constituinte. Para ser mais rigoroso, nas tabelas que serão apresentadas deveriam constar as seguintes especificações: 1) Anteprojeto de junho de 1987; 2) Projeto de julho de 1987; 3) Substitutivo do relator de agosto de 1987; 4) Substitutivo de relator (2a.) de setembro de 1987; 5) Projeto (A) de novembro de 1987; 6) Projeto (A) de dezembro de $1987 ; 7)$ Projeto $\left(2^{\circ}\right.$. turno) de julho de $\left.1988 ; 8\right)$ Projeto (B) $\left(2^{\circ}\right.$. turno) de agosto de 1988 . O
}

Comissão da Organização dos Poderes e Sistemas de Governo, a proposta do "Centrão" e a proposta apresentada pela Confederação Nacional do Ministério Público - e o texto final promulgado na Constituição. A ideia é demonstrar que os parlamentares reviram pontos importantes, reforçando a interpretação de que houve reflexão e maturação, até a apresentação do texto final, no qual o MP aparece como uni agente independente dos Poderes de Estado e com a atribuição da defesa de interesses da sociedade.

Nas tabelas 2 e 3 é possível constatar que a tendência em separar o Ministério Público do Poder Executivo ou de qualquer outro Poder de Estado é uma constante em todos os projetos. A diferença é que em alguns casos o MP constava de um Capítulo à parte (Anteprojetos de junho e julho de 1987, da Comissão da Organização dos Poderes e Sistemas de Governo e da "Carta de Curitiba) e em outros aparece como uma Seção de um Capítulo. Estes Capítulos eram chamados "Das Funções Essenciais Ao Exercício dos Poderes" (Anteprojeto de agosto de 1987), "Das Funções Essenciais À Administração da Justiça" (Anteprojetos de setembro, novembro e dezembro de 1987, julho e agosto de 1988 e do "Centrão") ou "Das Funções Essenciais À Justiça" (Constituição de 1988).

projeto de setembro de 1988, chamado de "C", foi o aprovado por 474 votos a favor, 15 contra e seis abstenções e transformou-se na Constituição (BONAVIDES \& ANDRADE: 1989; pag. 468). Portanto, onde se lê "Constituição" nas tabelas, deve-se considerar também como o projeto de setembro. 
Tabela 2

Localização do Ministério Público/ Relatoria da Assembleia

\begin{tabular}{|c|c|c|c|c|c|c|c|}
\hline \multicolumn{7}{|c|}{1987} & \multirow[b]{2}{*}{$\begin{array}{c}\text { Constituição } \\
\text { de } 1988\end{array}$} \\
\hline JunhoJulho & Agosto & Set. & Nov. & Dez. & Julho & Agosto & \\
\hline $\begin{array}{l}\text { Concluído } \\
\text { à parte }\end{array}$ & $\begin{array}{l}\text { Incluído como } \\
\text { Seção II no } \\
\text { capítulo "Das } \\
\text { funções } \\
\text { essenciais ao } \\
\text { exercício dos } \\
\text { poderes" }\end{array}$ & $\begin{array}{l}\text { Incluído como } \\
\text { Seção II no } \\
\text { capítulo "Das } \\
\text { funções } \\
\text { essenciais à } \\
\text { administração } \\
\text { da justiça" }\end{array}$ & IDEM & IDEM & $\begin{array}{l}\text { Incluído como } \\
\text { Seção I no } \\
\text { capítulo"Das } \\
\text { funções } \\
\text { essenciais à } \\
\text { administração } \\
\text { da justiça" }\end{array}$ & IDEM & $\begin{array}{l}\text { Incluído como } \\
\text { Seção I no } \\
\text { Capítulo "Das } \\
\text { funções } \\
\text { essenciais à } \\
\text { justiça" }\end{array}$ \\
\hline
\end{tabular}

Fonte: Senado Federal

Tabela 3

Localização do Ministério Público/ Centrão, Comissão dos Poderes e Sistemas de Governo e da "Carta de Curitiba"

\begin{tabular}{lll}
\hline \multicolumn{1}{c}{ CENTRÃO } & \multicolumn{1}{c}{ COMISSÃO } & CARTA DE CULTURA \\
\hline Incluído no Capítulo "Das funções & Incluído como Capítulo & Capítulo à parte \\
essenciais à administração da & à parte & \\
Justiça" como Seção à parte & & \\
\hline
\end{tabular}

Fonte: Senado Federal, Mazzilli: 1993

Nos anteprojetos em que o Ministério Público aparecia como Seção de um Capítulo outros agentes da Justiça eram incluídos. Assim, nos anteprojetos de agosto a dezembro de 1987, a outra Seção era "Da Advocacia", que se dividia na Subseção das "Disposições Gerais", na Subseção "Das Procuradorias Gerais Da União, Dos Estados e Do Distrito Federal", responsável pela defesa e consultoria jurídica do Executivo e da Administração em geral - e na Subseção "Das Defensorias Públicas”. Em julho de 1988, permanecendo também em agosto do mesmo ano, o título de "ProcuradoriaGeral" foi substituído pelo definitivo "Da Advocacia Geral Da União" e fundiu-se em uma única Seção "Da Advocacia e Da Defensoria Pública" ambos idênticos ao projeto do Centrão de janeiro de 1988-, sendo este o adotado em definitivo pela Constituição de 1988.

\footnotetext{
${ }^{8}$ No anteprojeto da Comissão da Organização dos Poderes e Sistemas de Governo, a Procuradoria era denominada de "Procuradoria Geral da União" e incluída como Seção do Capítulo referente ao Executivo.
}

A definição do Ministério Público sofreu poucas alterações ao longo do processo (tabelas 4 e 5). A que mais difere é a proposta apresentada pela Conamp através da "Carta de Curitiba" - que não inclui a função jurisdicional e os interesses sociais e individuais indisponíveis, mas a defesa da Constituição e do interesse público. Nos anteprojetos, a única diferença é quanto à questão do regime democrático: o MP é responsável pela "defesa do regime democrático" antes de todas as outras funções (junho, julho de 1987 e no anteprojeto da Comissão da Organização dos Poderes e Sistemas de Governo) ou da "legalidade democrática" (agosto de 1987) ou, a definitiva, da "ordem jurídica" e do "regime democrático" (setembro, novembro, dezembro de 1987; julho, agosto de 1988; Constituição de 1988 e do "Centrão).

\section{Tabela 4}

Definição do MP/ Relatoria da Assembleia

junho de 1987 "O Ministério Público é instituição permanente,
essencial à função jurisdicional do Estado, incumbindolhe a defesa do regime democrático, da ordem jurídica e dos interesses socais e individuais indisponíveis"

\begin{tabular}{|c|c|}
\hline julho de 1987 & Idem \\
\hline agosto de 1987 & $\begin{array}{l}\text { "O Ministério Público é instituição permanente, essencial } \\
\text { à função jurisdicional do Estado, incumbindo-lhe a defesa } \\
\text { da ordem jurídica da legalidade democrática, e dos } \\
\text { interesses socais e individuais indisponíveis" }\end{array}$ \\
\hline setembro de 1987 & $\begin{array}{l}\text { "O Ministério Público é instituição permanente, } \\
\text { essencial à função jurisdicional do Estado, incumbindo- } \\
\text { lhe a defesa da ordem jurídica e do regime democrático, } \\
\text { e dos interesses sociais e individuais indisponíveis" }\end{array}$ \\
\hline novembro de 1987 & $\begin{array}{l}\text { "O Ministério Público é instituição permanente, } \\
\text { essencial á função jurisdicional do Estado, incumbindo- } \\
\text { lhe a defesa da ordem jurídica, do regime democrático e } \\
\text { dos interesses sociais e individuais indisponíveis" }\end{array}$ \\
\hline dezembro de 1987 & Idem \\
\hline julho de 1988 & Idem \\
\hline agosto de 1988 & Idem \\
\hline Constituição & Idem \\
\hline
\end{tabular}

Fonte: Senado Federal 
Tabela 5

Definição do MP/ Comissão da Organização dos Poderes e Sistemas de Governo, Centrão e "Carta de Curitiba".

"O Ministério Público é instituição permanente, essencial à função jurisdicional do Estado, incumbindo-lhe a defesa do regime democrático, da ordem jurídica e dos interesses sociais e individuais indisponíveis"

COMISSÃO

"O Ministério Público é instituição permanente essencial à função jurisdicional do Estado, incumbindo-lhe a defesa da ordem

jurídica, do regime democrático e dos interesses sociais e individuais indisponíveis".

"O Ministério Público, instituição permanente do Estado, é

CARTA responsável pela defesa do regime democrático e do interesse público,

CURITIBA velando pela observância da Constituição e da ordem jurídica"

Fonte: Senado Federal e Mazzilli: 1993.

Se o principio geral de um Ministério Público independente e com atribuições amplas foi aceito em todos os anteprojetos, corroborando parte de minha hipótese, falta demonstrar que os constituintes criaram mecanismos mais rigorosos de controle sobre a instituição do que aqueles propostos pela Conamp através da "Carta de Curitiba". Neste sentido, o primeiro ponto a ser observado diz respeito à indicação do Procurador-Geral da República e dos ProcuradoresGerais de Justiça dos estados ${ }^{9}$ (tabelas 6 e 7).
Tabela 6

Indicação e Destituição do Procurador-Geral/ Relatoria da Assembleia

\begin{tabular}{|c|c|c|c|c|c|}
\hline & $\begin{array}{c}\text { Junho/julho de } \\
1987 \\
\end{array}$ & $\begin{array}{c}\text { Agosto de } \\
1987\end{array}$ & $\begin{array}{c}\text { set/nov/ dez de } \\
1987\end{array}$ & $\begin{array}{c}\text { julho/agosto de } \\
1988 \\
\end{array}$ & Constituição \\
\hline $\begin{array}{l}\text { Escolha do } \\
\text { Procurador- } \\
\text { Geral }\end{array}$ & $\begin{array}{l}\text { Cada MP elegerá } \\
\text { seu Procurador- } \\
\text { Geral na forma da } \\
\text { lei entre os } \\
\text { integrantes de } \\
\text { carreira. Mandato } \\
\text { de três anos de } \\
\text { recondução. }\end{array}$ & $\begin{array}{c}\text { Eleição por } \\
\text { lista tríplice, } \\
\text { na forma da } \\
\text { lei, entre os } \\
\text { integrantes } \\
\text { de carreira } \\
\text { com } \\
\text { mandato de } \\
\text { dois anos de } \\
\text { recondução. }\end{array}$ & $\begin{array}{c}\text { MP Federal: } \\
\text { Formação de lista } \\
\text { tríplice entre os } \\
\text { integrantes de } \\
\text { carreira. Mandato } \\
\text { de dois anos, com } \\
\text { recondução. MP } \\
\text { Estaduais: Eleição } \\
\text { direta entre os } \\
\text { integrantes de } \\
\text { carreira. Mandato } \\
\text { de dois anos com } \\
\text { recondução. }\end{array}$ & $\begin{array}{c}\text { MP Federal: } \\
\text { nomeado pelo } \\
\text { Presidente entre } \\
\text { os integrantes de } \\
\text { carreira, } \\
\text { aprovação pelo } \\
\text { Senado com } \\
\text { dois anos de } \\
\text { mandato e } \\
\text { recondução. MP } \\
\text { Estadual: Lista } \\
\text { tríplice, entre os } \\
\text { integrantes do } \\
\text { Governador } \\
\text { com mandato de } \\
2 \text { anos e } \\
\text { recondução. }\end{array}$ & IDEM \\
\hline $\begin{array}{l}\text { Destituição do } \\
\text { Procurador- } \\
\text { Geral }\end{array}$ & $\begin{array}{l}\text { Não é previsto } \\
\text { a destituição. }\end{array}$ & $\begin{array}{c}\text { Destituição } \\
\text { por } 2 / 3 \text { do } \\
\text { Senado ou } \\
\text { Assembleia } \\
\text { Legislativa, } \\
\text { conforme o } \\
\text { caso. }\end{array}$ & $\begin{array}{l}\text { Destituição por } \\
\text { 2/3 do Senado (ou } \\
\text { Assembleia } \\
\text { Legislativa), por } \\
\text { abuso de poder ou } \\
\text { grave omissão por } \\
\text { representação do } \\
\text { presidente } \\
\text { (governador), da } \\
\text { maioria do } \\
\text { Senado } \\
\text { (Assembleia) ou } \\
\text { do órgão } \\
\text { colegiado. } \\
\end{array}$ & $\begin{array}{c}\text { MP Federal: } \\
\text { destituição pelo } \\
\text { Presidente com } \\
\text { aprovação da } \\
\text { u maioria absoluta } \\
\text { r do Senado. MP } \\
\text { Estadual: } \\
\text { destituição pela } \\
\text { maioria do } \\
\text { Senado } \\
\text { (Assembleia) ou } \\
\text { do órgão } \\
\text { colegiado. }\end{array}$ & IDEM \\
\hline
\end{tabular}

Fonte: Senado Federal
${ }^{9}$ A substituição do título de Procurador-Geral pelo de Promotor- Geral, como queria a Conamp, não foi aceita. 
Tabela 7

Indicação e Destituição do Procurador-Geral/ Comissão da Organização dos Poderes e Sistema de Governo, Centrão e "Carta de Curitiba".

\begin{tabular}{|c|c|c|c|}
\hline & COMISSÃO & CENTRÃO & CARTA DE CURITIBA \\
\hline $\begin{array}{c}\text { Escolha do } \\
\text { Procurador-Geral }\end{array}$ & $\begin{array}{c}\text { Cada MP elegerá } \\
\text { seu Procurador } \\
\text { Geral na forma da } \\
\text { lei entre os } \\
\text { integrantes de } \\
\text { carreira. Mandato } \\
\text { de três anos com } \\
\text { recondução. }\end{array}$ & $\begin{array}{l}\text { MP Federal: Nomeado } \\
\text { pelo Presidente entre os } \\
\text { integrantes de carreira, } \\
\text { com aprovação do } \\
\text { Senado com mandato } \\
\text { correspondente ao do } \\
\text { Presidente. MP Estadual: } \\
\text { indicado pelo } \\
\text { Governador, dentre os } \\
\text { integrantes de carreira, na } \\
\text { forma da Lei estadual. }\end{array}$ & $\begin{array}{c}\text { MP Federal: indicado } \\
\text { pelo Presidente entre } \\
\text { cidadãos maiores de } 35 \\
\text { anos, de notável saber } \\
\text { jurídico e reputação } \\
\text { ilibada, devendo ser } \\
\text { aprovado pelo Senado } \\
\text { Federal e servirá por } \\
\text { tempo determinado não } \\
\text { excedendo o período } \\
\text { presidencial } \\
\text { correspondente. MP } \\
\text { Estadual: elegerá seu } \\
\text { Procurador-Geral, na } \\
\text { forma de lei local, para } \\
\text { mandato de } 2 \text { anos, } \\
\text { permitindo-se uma } \\
\text { recondução, entre os } \\
\text { integrantes de carreira }\end{array}$ \\
\hline $\begin{array}{c}\text { Destituição do } \\
\text { Procurador-Geral }\end{array}$ & $\begin{array}{l}\text { Não é prevista a } \\
\text { destituição }\end{array}$ & $\begin{array}{l}\text { MP Federal: exoneração } \\
\text { com autorização da } \\
\text { maioria do Senado. MP } \\
\text { Estadual: não previsto. }\end{array}$ & $\begin{array}{l}\text { MP Federal: Somente } \\
\text { poderá ser destituído } \\
\text { em caso de abuso de } \\
\text { poder ou omissão } \\
\text { grave, por deliberação } \\
\text { de } 2 / 3 \text { do Colégio } \\
\text { Superior. MP } \\
\text { Estadual: Idem. }\end{array}$ \\
\hline
\end{tabular}

Fonte: Senado Federal e MAZZILLI: 1993

A partir das duas tabelas acima o argumento ganha força: por um lado, a maior derrota da Conamp foi, justamente, no que se refere às formas de indicação e destituição dos Procuradores-Gerais e, por outro, é sobre esse item que os Constituintes buscaram criar mecanismos de controle sobre a instituição. Senão vejamos:
A Conamp defendia que a indicação do Procurador-Geral da República fosse feita pelo Presidente da República com aprovação do Senado Federal. Por outro lado, a destituição só seria possível em dois casos: se houvesse abuso de poder ou omissão grave. Ou seja, não se poderia propor a substituição do Procurador-Geral por outros motivos, buscando garantir desta forma a não utilização de critérios exclusivamente políticos, por exemplo, para propor o afastamento do "chefe" da instituição. Outra maneira de limitar interferências de outros Poderes seria a aprovação do mecanismo segundo o qual a destituição só poderia ser aprovada pelo próprio Colégio Superior do Ministério Público. Em outras palavras: garantir-se-ia o cargo contra injunções políticas e limitar-se-ia a interferência e a fiscalização por parte dos outros Poderes de Estado. Em contrapartida, a proposta promulgada garante maior liberdade ao Presidente para propor o afastamento - não listando os motivos - e exige também a participação do Poder Legislativo - aprovação pelo Senado Federal. O cargo deixa de ser de confiança do Presidente da República - e, portanto, totalmente dependente de sua exclusiva vontade, como era pela antiga Constituição -, mas controlado externamente por outros Poderes de Estado. Pela tabela 6 é possível acompanhar como estes mecanismos de controle vão evoluindo, de maneira gradativa, da mínima interferência do Executivo e do Legislativo (como era o anteprojeto de junho e julho de 1987) para o modelo final aprovado na Constituição de 1988.

Quanto ao Procurador-Geral de Justiça dos estados, a proposta era menos clara. A "Carta de Curitiba" sugeria que os constituintes limitassem o mandato em dois anos, permitissem uma recondução e que o escolhido fosse integrante dos quadros do próprio MP. A destituição, por sua vez, ocorreria somente em casos de abuso de poder ou omissão grave e decidida pelo Colégio Superior da própria instituição, sem a interferência do Governador do Estado. Dessa forma, como deixou claro o Secretário-Geral da Confederação Nacional do Ministério Público (Antônio Dal Pozzo) nos debates da Subcomissão do Poder Judiciário e do Ministério Público, a estratégia era garantir mais liberdade para os MPs dos estados do que para o Federal. Nos anteprojetos de setembro, novembro e dezembro de 1987 os constituintes foram mais generosos que a própria proposta da Conamp: previa-se a eleição direta. Somente a partir do anteprojeto de julho de 1988 foi que o modelo da lista tríplice escolhida pelo Governador passou a constar do texto do relator e, finalmente, da própria Constituição. Apenas a 
forma de seleção dos três nomes levados ao chefe do executivo estadual foi deixada em aberto para uma futura decisão.

A questão das "vedações" dos integrantes do Ministério Público em preencher cargos na administração pública e exercer atividade políticapartidária é outra questão interessante para a comparação entre o que foi proposto pela Conamp e o que ficou decidido pelos constituintes. Pela "Carta de Curitiba", previa-se a liberdade para o exercício de "cargo público eletivo" e "administrativo de excepcional relevância". Desde o princípio este ponto foi vetado pelos constituintes, revelando o temor que promotores e procuradores pudessem utilizar-se do cargo para lançar-se politicamente ou privilegiar aliados. Assim, no projeto da Comissão da Organização dos Poderes e Sistemas de Governo, como nos anteprojetos de junho e julho de 1987, os integrantes do MP passaram a ter as "mesmas vedações e gozarão das mesmas garantias, vencimentos e vantagens conferidas aos magistrados". No anteprojeto de agosto de 1987, a questão passou a ter redação bem mais explícita, vedando-se "qualquer outra função pública" e "atividade político- partidária". No anteprojeto seguinte, de setembro, e também no de novembro e dezembro, previa-se a possibilidade de atividade político-partidária desde que com "prévio afastamento, na forma da lei". A partir do anteprojeto de julho de 1988, este ponto ganhou sua redação definitiva, tendo sido vedada a atividade político-partidária, "salvo exceções previstas na lei". Esta exceção foi definida no "Ato das Disposições Transitórias", prevendo-se que teriam direitos a atividades político-partidárias aqueles ingressos no Ministério Público antes de 1988. Esta exceção é bastante representativa do que se passou no período constituinte em relação ao MP: por um lado, uma sinalização por parte dos constituintes de que não aceitariam simplesmente as propostas da Confederação Nacional do Ministério Público e que estes exerceram sua atividade de maneira crítica; por outro lado, a concessão de pequenas vantagens, cedendo em alguns pontos à pressão da Conamp.

A relação do Ministério Público com a Polícia também foi outro ponto em que os constituintes cederam à pressão, mas desta vez da Associação dos Delegados. Ou seja, a proposta promulgada limita a ação do $\mathrm{MP}$, contrariamente àquilo que foi reivindicado pela Conamp. Pela "Carta de Curitiba", a Confederação Nacional do Ministério Público elencava como atividade privativa do Ministério Público a promoção da ação penal pública e a supervisão dos "procedimentos investigatórios, podendo requisitá-los e avocá-los". No anteprojeto da Comissão da Organização dos Poderes e Sistemas de Governo, de junho e julho de 1987 os constituintes decidiram autorizar aos integrantes do Ministério Público a requisição de atos investigatórios, a supervisão da investigação criminal e, inclusive efetuar a correição da Polícia - "sem prejuízo da permanente correição judicial". No anteprojeto de 1987 inicia-se a construção daquilo que seria promulgado na Carta Constitucional: direito de "requisitar a instauração de inquérito policial, determinar diligências investigatórias, podendo supervisionar a investigação criminal”. Em setembro, novembro e dezembro de 1987 o relator indicava que ao Ministério Público competia o exercício do "controle externo sobre a atividade policial" e que seriam sempre fundamentadas as requisições de diligências investigatórias e instauração de inquérito policial. Pelo projeto do Centrão, de janeiro de 1988, a única diferença é que o controle externo da atividade policial seria regulada por Lei complementar - proposta aceita nos projetos finais e na própria Constituição. A partir do projeto de julho de 1988, incluindo-se aí o de agosto e a própria Constituição, é definido o outro ponto aqui discutido como direito do Ministério Público: "requisitar diligências investigatórias e determinar a instauração de inquérito policial, indicados os fundamentos jurídicos de suas manifestações processuais". Em outras palavras, os constituintes limitaram em muito o papel do Ministério Público nas investigações criminais se comparado ao que foi proposto pela Confederação Nacional da própria entidade. Mantiveram assim a "divisão do trabalho" em relação à questão penal, recusando-se a aumentar os poderes do Ministério Público nesse ponto.

Se na questão criminal o Ministério Público não recebeu as atribuições desejadas, em relação à ação civil pública - um dos pontos fundamentais para a diferenciação da instituição quando comparada a outros países - os constituintes garantiram amplos poderes ao MP, indicando seu desejo de construir uma instituição responsável pelo reforço da cidadania no que se refere à fiscalização dos agentes públicos e na garantia dos direitos coletivos. Apesar de todos os anteprojetos indicarem que outros agentes poderiam lançar mão de tal instrumento jurídico, a ação civil consta da Seção destinada ao MP e a instituição é o único agente responsável pela instauração do inquérito civil, demonstrando, portanto, seu papel de agente privilegiado frente a este procedimento. Somado a isto, o 
Ministério Público tornou-se um dos agentes responsáveis por "zelar pelo efetivo respeito dos Poderes Públicos e dos serviços de relevância pública aos direitos assegurados nesta Constituição."

\section{Conclusão}

A Constituição, e o próprio processo Constituinte, como afirmam Amaury de Souza e Bolívar Lamounier, pode ser vista, não simplesmente como uma resposta a demandas e pressões imediatas e de curto prazo, mas como um esforço coletivo para passar a limpo o país, desafiando atitudes profundamente arraigadas de hostilidade ou de ceticismo com relação ao regime democrático (SOUZA \& LAMOUNIER: 1990; p. 101).

Assim, ao analisar o Ministério Público, seu novo desenho institucional e como este se deu na Assembleia Nacional Constituinte, o objetivo não foi somente reconstruir o processo, mas entendê-lo como reflexo de um determinado "ambiente", propício à aceitação de um agente que extrapola seu papel clássico de persecução penal. Afinal, como aponta toda a literatura sobre a Assembleia Nacional Constituinte de 1987/88, grupos de pressão (lobbies) foram uma constante durante os trabalhos que resultaram na Carta Magna de 1988, não significando, entretanto, que todos viram suas demandas atendidas. Neste sentido - sem querer afirmar que a Confederação Nacional do Ministério Público foi a única vitoriosa - a aprovação desse modelo de Ministério Público não pode ser explicada somente como um "cochilo" por parte dos deputados e senadores constituintes. Pelo contrário, se todos fizeram pressão, mas nem todos foram tão bem sucedidos como a Confederação Nacional do Ministério Público, isso significa que a proposta tinha espaço ou "ambiente" para sua aceitação.

Assim, argumento neste trabalho que para compreender o desenho institucional do MP pós-1988 não basta afirmar que havia um lobby da instituição. É necessário complementar com uma pergunta: por que os constituintes aceitaram o princípio geral de um Ministério Público autônomo e responsável pela tutela de direitos coletivos?

Como apontei ao longo deste artigo, a resposta não se resume a um ponto específico, mas aponta para a conjunção de vários fatores. O primeiro é o próprio período em que todo o processo constitucional se desenvolveu. Como se sabe, a convocação da Assembleia Nacional Constituinte representava a última etapa da transição para a democracia. A Constituição “cidadã", como a chamava o Deputado Ulysses Guimarães, tinha como função enterrar o "entulho autoritário" e plantar as novas bases para a consolidação do regime democrático. Isso se reflete em vários pontos da Carta Constitucional e, sem dúvida, no processo de construção do Ministério Público como agente responsável pela defesa de interesses coletivos da sociedade e do regime democrático.

Além desse elemento "conjuntural", o Ministério Público responde a diferentes aspectos da cultura política presentes na Assembleia Nacional Constituinte, representando uma síntese do que Souza e Lamounier (1990) chamaram de "idades geológicas" da cultura política: a percepção que os direitos individuais da tradição liberal não são suficientes; a identificação do Estado como agente privilegiado na regulação da economia e da cidadania; e, finalmente, a busca de alternativas à representação política através da democracia representativa e dos partidos políticos. O novo Ministério Público é facilmente "vendável" como projeto, pois, de certa forma, pode preencher estas diferentes concepções que balizaram a feitura da Carta Constitucional de 1988.

O Ministério Público, portanto, não é uma instituição diferenciada ou destoante do conjunto da Constituição. Pelo contrário. É coerente com os aspectos relevantes apontados por praticamente toda a bibliografia sobre a Assembleia Nacional Constituinte. Em primeiro lugar pela valorização da questão dos direitos coletivos; para muitos autores (SOUZA \& LAMOUNIER: 1990; COELHO: 1989) este ponto significa a mudança mais importante no texto constitucional quando comparado a outras Cartas Magnas brasileiras. Ora, o Ministério Público não é o agente privilegiado para exigir o cumprimento de tais direitos, sendo, portanto, intimamente ligado a esta novidade? Outro ponto é o papel fundamental do Judiciário para o jogo político e sua transformação em um Poder de Estado de fato (SouZA \& LAMOUNIER: 1990; SADEK \& ARANTES: 1994; Castro: 1997). Ora, o Ministério Público não é o agente privilegiado para "provocar" o Poder Judiciário, tendo inclusive atribuições que impedem que os cidadãos ajam sem sua intermediação (intervenção em estados e municípios ou mesmo a ação penal pública)?

Se o modelo adotado de Ministério Público liga-se organicamente à estrutura da Constituição, a explicação de que os constituintes não sabiam o que estavam votando pode e deve ser questionada. Um MP como reza o 
artigo 127 da Constituição Federal 10condiz perfeitamente com o ânimo que marcou os trabalhos de 1987/88.

\section{Bibliografia}

ARANTES, Rogério B. Direito e Política: Instituições Judiciais e Conflitos Coletivos. Paper apresentado na LASA (México) em 1997.

BobBIO, Norberto. Estado, Governo, Sociedade: para uma teoria geral da política. Paz e Terra, RJ, 1995.

Bonavides, Paulo \& ANDRAde, Paes de. História Constitucional do Brasil. Paz e Terra/Senado Federal, Brasília,1989.

Carneiro, Paulo C. P. O Ministério Público no Processo Civil e Penal, Ed. Forense, RJ,1995.

CASTRO, Marcus Faro de. "O Supremo Tribunal Federal e a Judicialização da Política", Rev. Brasileira de Ciências Sociais, vol. 12, n.34, junho de 1997.

Coelho, João G. L. "A Constituição Brasileira de 1988: Definições e Desafios" in Coelho, João G. L. \& Oliveira, Antônio C. N. A Nova Constituição: avaliação do texto e perfil dos constituintes, Revan, RJ, 1989.

FAORO, Raymundo. Os Donos do Poder, Ed. Globo, Porto Alegre, 1976. Assembleia Nacional Constituinte: a Legitimidade Recuperada, Brasiliense, SP, 1993.

HolandA, Sérgio Buarque. Raízes do Brasil, José Olympio, RJ, 1991.

KINZO, Maria D'Alva Gil. "O Quadro Partidário e a Constituinte" in LAMOUNIER, Bolívar (org.) De Geisel a Collor: $O$ Balanço da Transição, IDESP/Sumaré, SP, 1990.

LEAL, Victor Nunes. Coronelismo, Enxada e Voto, SP, Alfa-Ômega, 1978.
MANCuso, Rodolfo de Camargo. Ação Civil Pública: em Defesa do Meio Ambiente, Patrimônio Cultural e dos Consumidores: lei 7347/85e legislação complementar, Ed. Rev. dos Tribunais, SP, 1994.

MAZZILLI, Hugo Nigro. Regime Jurídico do Ministério Público, Saraiva, SP, 1993 O’DONNELL, Guillermo. "Democracia Delegativa?" Rev. Novos Estudos, n. 31, outubro de 1991.

REIS, Fábio Wanderley. "Direitos Humanos e Sociologia do Poder", Rev. Lua Nova, n. 15, outubro de 1988.

SADEK, Maria Tereza. O Ministério Público e a Justiça no Brasil, Sumaré, SP, 1997.

; ARANTES, Rogério B. "A Crise do Judiciário e a Visão dos Juízes”, Rev. USP, n.21, SP, março/abril de 1997.

SOlA, Lourdes; GaRman, Christopher \& MARQues, Moisés. Central Banking, Democratic Governance and Political Authority: The Case of Brazil in a Regional Perspective. Paper apresentado na IPSA (Coréia) em agosto de 1997.

Weber, Max. Ciência e Política: Duas Vocações, Cultrix, SP, 1972.

WeFFort, Francisco. O Populismo na Política Brasileira, Paz e Terra, RJ, 1980.

\section{Documentos Oficiais}

Constituição Federal

Anais da Assembleia Nacional Constituinte

\footnotetext{
10 “O Ministério Público é instituição permanente, essencial à função jurisdicional do Estado, incumbindo-lhe a defesa da ordem jurídica, do regime democrático e dos interesses sociais e individuais indisponíveis".
} 